\title{
Jogos de Empresa em Gestão de Projetos de Software: Desenvolvimento de uma Ferramenta Baseada na Dinâmica de Sistemas
}

\author{
Janaína Cóffani
}

Orientador: Prof. Dr. Paulo Cesar Masiero

Dissertação apresentada ao Instituto de Ciências Matemáticas e de Computação - ICMC-USP, como parte dos requisitos para obtenção do título de Mestre em Ciências - Área: Ciências de Computação e Matemática Computacional.

USP - São Carlos

Setembro de 2000 


\section{Agradecimentos}

À Deus pela força, proteção e bençãos.

À minha avó Aparecida, minha mãe Jussara e meu namorado José Eduardo que sempre estiveram presentes me apoiando e incentivando em todos os momentos com muito carinho e paciência.

À meu orientador Prof. Dr. Paulo Cesar Masiero pelo incentivo, confiança, paciência, orientação, dedicação e todos os ensinamentos sem os quais não seria possível realizar este trabalho.

Ao Prof. Reginaldo por toda colaboração e ajuda em todos os momentos que precisei.

À Prof. Rosely pela amizade, incentivo e pelas boas e gostosas conversas durante todo esse tempo.

Ao grande amigo Enzo por sua amizade, colaboração, atenção e disposição apresentadas em todas as vezes que precisei de ajuda. trabalho.

Ao Reginaldo e Raul que me ajudaram muito durante o desenvolvimento deste

Às minhas amigas de "coração" que permaneceram sempre presentes pela amizade, carinho, compreensão e por todos os bons momentos que passamos juntas: Andi, Vera, Paty e Maristela.

Aos amigos conquistados durante todos esses anos pela amizade e pelos bons momentos juntos: Larissa, Rejane, Marisa, Jo, Dani, Claudinho, Will, Walter, Mario, Meire, João, Sadau, Waine, Eglen, Tati(William).

Ao pessoal do Labes: Mayb, Taty, Luciana, Andréa, Aline, Ellen, Auri, Adenilso, Rodrigo, Jusane, Elisandra, Rodrigo Fantinatti, Willie.

À Marlene pela simpatia, disposição e atenção dispensadas.

Ao pessoal da biblioteca, da seção de pós e a todos os funcionários do ICMC que contribuíram de alguma forma com este trabalho.

Ao CNPq pelo auxilio financeiro. 


\section{Resumo}

Os Jogos de Empresa são amplamente utilizados para treinamento na área de administração de empresas por proporcionarem uma forma prática e experimental de aprendizado. Esta dissertação explora o uso de modelos baseados na Dinâmica de Sistemas para criação de Jogos de Empresa para o treinamento de gerentes de projeto de software. Isso é feito apresentando-se um jogo para a gestão de recursos humanos em projetos de software baseado em um modelo dinâmico desenvolvido por Abdel-Hamid e Madnick na década de 1980.

Este trabalho apresenta também a extensão de uma ferramenta desenvolvida para edição e simulação de sistemas, Cycles, para dar apoio automatizado à criação de jogos baseados na Dinâmica de Sistemas. Essa ferramenta estendida permite que várias equipes possam jogar e analisar suas decisões. $O$ coordenador das equipes jogadoras pode estabelecer os parâmetros e metas do jogo e acompanhar on-line o desenrolar do jogo. 


\begin{abstract}
Enterprise Games are widely used for training in the area of business management, providing a practical administration and experimental way of learning. This dissertation explores the use of models based on System Dynamics for the creation of Enterprises Games for the training of software project managers. This is done presenting a game created to help training software project leaders on the management human resources for software projects. This game is based in a model developed by Abdel-Hamid and Madnick.

This dissertation shows also an extension of a tool developed for edition and simulation of System Dynamics models, Cycles, to support creation and execution of games based on System Dynamics. This extended tool allows various teams to play and analyze their decisions. The coordinator of the playing teams can establish the parameters and goals of the game and to follow on-line the game development.
\end{abstract}




\section{Índice}

Capítulo 1-Introdução

1.1 Contextualização do Problema __ _

1.2 Motivação ___ 3

1.3 Objetivos _ 3

1.4 Organização da Dissertação ___ 4

Capítulo 2-Dinâmica de Sistemas _ 5

2.1 Consideraçōes Iniciais___

2.2 Simulação

$\begin{array}{ll}\text { 2.2.1 Classificação dos Modelos de Simulação___ } & 8 \\ \text { 2.2.2 Metodologia da Simulação } & \end{array}$

$\begin{array}{ll}\text { 2.2.2 Metodologia da Simulação _ } & \\ \text { 2.2.3 Linguagens de Simulação__ } & 11\end{array}$

2.3 Introdução à Dinâmica de Sistemas ___ 11

2.4 Um Exemplo de Sistema Dinâmico ___ 13

2.5 Ferramentas para Edição e Simulação de Sistemas Dinâmicos ___ 17

2.6 Considerações Finais__ 22

Capítulo 3-Jogos de Empresa___ 23

3.1 Considerações Iniciais ___ 25

3.2 Introdução aos Jogos de Empresas ___ 25

3.2.1. Histórico

3.2.2 Classificação______ 28

3.2.3 Jogos no Processo de Ensino/Aprendizagem _ 29

3.3 A Estrutura dos Jogos de Empresas __ 31

3.3.1 Técnica — 31

3.3.2 Componentes Básicos para o Projeto de um Jogo ___ 32

3.3.3 A Dinâmica da Aplicação dos Jogos de Empresas__ 34

3.4 Jogos na Área de Gestão de Projetos de Software ___ 35

3.5 Considerações Finais___ 41

Capitulo 4 - Adaptaçäo do Cycles para Apoiar Jogos ___ 42

4.1 Consideraçōes Iniciais____ 43

4.2 O Processo de Adaptação da Ferramenta Cycles____ 43

4.3 Arquitetura da Ferramenta de Apoio a Jogos de Empresas____ 45

4.4 Extensōes Realizadas__ 46

4.4.1 Modelagem Conceitual__ 46

4.4.2 Aspectos de Projeto da Base de Dados___ 50

4.4.3 Aspectos de Implementaçăo e da Interface da Ferramenta______ 53

4.5 Considerações Finais__ 57

Capitulo 5 - Um Jogo para Gestão de RH em Projetos de Software _ 58

5.1 Considerações Iniciais___ 59

5.20 Modelo Dinâmico Alterado __ 59 
5.30 Jogo 61

5.3.1 Objetivo do Jogo

5.3.2 Variáveis Definidas no Início do Jogo

5.3.3 Variáveis Alteráveis Durante o Jogo

5.3.4 Variáveis Visíveis do Jogo

5.4 Dinâmica do Jogo

5.4.1 Procedimento para Criação de um Jogo 64

5.4.2 Execução do Jogo

5.5 Avaliação da Ferramenta

5.6 Considerações Finais 72

Capítulo 6 - Conclusöes 73

6.1 Consideraçōes Gerais 74

6.2 Contribuições 74

6.3 Trabalhos Futuros 75

Referência Bibliográficas 76

Anexo A 80 


\section{Lista de Figuras}

Figura 2.1-Subsistemas do Projeto de Software (Abdel-Hamid \& Madnick, 1991) 14

Figura 2.2 - Modelo de um Subsistema de Recursos Humanos voltado para Processos de Software (Abdel-

Hamid \& Madnick, 1991)

15

Figura 2.3 - Estrutura geral das ferramentas

Figura 2.4 - Interface da Primeira Camada de Modelagem do Stella ___

Figura 2.5 - Interface da Segunda Camada de Modelagem do Stella 19

Figura 2.6 - Interface da Terceira Camada de Modelagem do Stella -Equaçōes ___ 19

Figura 2.7 - Arquitetura da Ferramenta Cycles___ 20

Figura 2.8 - Interface da Ferramenta Cycles

Figura 2.9 - Modelagem do Subsistema de Recursos Humanos voltado para Processos de Software (Abdel-

Hamid \& Madnick, 1991) em Ediçäo __ 21

Figura 2.10 - Simulação do Sistema

Figura 3.1 -Interface do Usuário de uma Ferramenta de Treinamento de Gerenciamento de Projeto de

Sofhware Merril \& Collofello, 1997) 38

Figura 4.1-Arquitetura da Ferramenta de Apoio a Jogos ___ 45

Figura 4.2 - Diagrama de Casos de Uso ___ 47

Figura 4.3 - Fluxo da Dinâmica de Aplicação do Jogo ___ 48

Figura 4.4 - Diagrama de Classes - Modelo Conceitual ____ 49

Figura 4.5 - Modelo Entidade-Relacionamento ___ 50

Figura 4.6-Relacionamentos entre as Tabelas-MS Access 97

Figura 4.7 - Interface de Inicio da Ferramenta ___ 54

Figura 4.8 - Interface do Administrador____ 54

Figura 4.9-Interface do Coordenador

Figura 4. lo Interface do Coordenador (Criar elou Preparar um Jogo) ___ 55

Figura 4.11 Interface das Equipes Jogadoras __ 56

Figura 5.1 - Modelo de Gerenciamento de Recursos Humanos Modificado _______ 60

Figura 5.2 -Interface do Coordenador ___ _ _ 65

Figura 5.3 -Interface para Modelagem da Dinâmica de Sistemas ___ 65

Figura 5.4 - Interface para Inclusão de um Jogo ___ 66

Figura 5.5 - Interface para Alteração ou Preparação de um Jogo ___ 67

Figura 5.6 - Passos Executados em um Partida do Jogo ___ 67

Figura 5.7 - Interface do Coordenador para Escolha do Jogo _______ 68

Figura 5.8 - Interface da Equipe 2 no Inicio do Jogo ____ 69

Figura 5.9a - Interface Visualizada de uma Equipe durante a Execuçâo do Jogo 70

Figura $5.9 b$ - Interface Visualizada de uma Equipe durante a Execução do Jogo ___ 70

Figura 5. 10 - Interface do Coordenador durante a Execução do Jogo ___ _ 71

\section{Lista de Quadros}

Quadro 2.1 - Definições de Simulação

Quadro 2.2 - Notaçāo da Dinámica de Sistemas _____ 12

Quadro 3.1-Definiçöes de Jogos de Empresas 26

Quadro 3.2 - Um Processo Interativo de Desenvolvimento de uma Ferramenta de Simulação de Treinamento

Baseada na Dinâmica de Sistemas (Merril \& Collofello, 1997) ___ 36

Quadro 3.3 - Os Beneficios Potenciais de uma Ferramenta Baseada na Dinâmica de Sistemas Merril \&

Collofello, 1997)

Quadro 4.1-Descrição dos Casos de Uso

Quadro 4.2 - Tabelas _____ 51

Quadro 4.3 - Tipos de Dados da Tabela Jogo _____ 52

Quadro 4.4 - Tipos de Dados da Tabela Usuário ___ 53

Quadro 4.5 - Tipos de Dados da Tabela Objetologo______ 53

Quadro 4.6 - Tipos de Dados da Tabela JogaPartida____________________ 


\section{Lista de Tabelas}

Tabela 2.1 - Valores Iniciais e Expressões do Modelo

Tabela 3.1 - Resultados Cumulativos de Jogos CASE (Youdon, 1996)

16

Tabela 3.2 - Resultados de um Jogo Baseado em Dinâmica de Sistemas (Youdon, 1996)

Tabela 3.3 - Resultados de um Jogo Baseado em Dinâmica de Sistemas (Continuação) (Youdon, 1996)

Tabela 3.4 - Resultados de um Jogo de Guerra em Dinâmica de Sistemas (Continuação) (Youdon, 1996) 40

Tabela 4.1 - Simulação do Sistema

22

Tabela 5.1 - Valores Iniciais e Expressóes do Modelo 


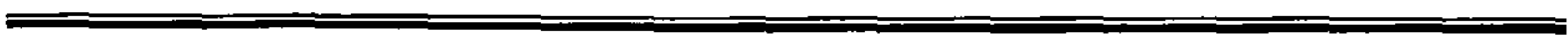

Capítulo 1 Introdução 


\subsection{Contextualização do Problema}

Durante as últimas décadas a Engenharia de Software vem passando por um constante processo evolutivo. Métodos, procedimentos e ferramentas foram adotados sucessivamente para apoiar uma ampla variedade de aplicaçc̃es empresariais. Gerentes de projeto que antes se concentravam no hardware, porque este era o item do desenvolvimento do sistema que apresentava maior custo, reconhecem a necessidade de uma abordagem mais sistemática e disciplinada para o desenvolvimento, operação e manutenção de software.

Anos atrás, com a chamada "Crise do Software", gerada por inúmeros problemas encontrados no desenvolvimento e manutenção de um volume crescente de software, o processo de desenvolvimento de software tornou-se alvo de interesse e estudo. Os problemas mais freqüentes encontrados no desenvolvimento de software foram causados por diversos fatores: falta de atenção ao processo de desenvolvimento de software, imprecisão nas estimativas de prazo e custos e alta taxa de erros. Somando-se a estes fatores têm-se as constantes falhas cometidas pelas gerentes de software. Gerentes sem nenhuma experiência ou treinamento recebiam e continuam recebendo ainda hoje a responsabilidade pelo desenvolvimento de projetos de software.

Desde a época da "Crise do Software", muitos esforços foram feitos para tornar o processo de desenvolvimento de software mais eficiente. Modelos de ciclo de vida baseados em várias fases foram introduzidos e implementados, métricas e estimativas de software começaram a ser utilizadas e a importância da qualidade de software foi reconhecida.

Entretanto, a ineficiência no gerenciamento do plano, custo e qualidade do desenvolvimento de projetos de software continua ainda hoje importunando a maioria dos projetos de software. Muitos desses projetos de software poderiam ser bem sucedidos se certos erros comuns cometidos por gerentes de projeto fossem evitados. Segundo Boehm (1981), deficiências em gerenciamento podem aumentar o custo do software mais rapidamente que qualquer outro fator.

Um bom gerente de projetos necessita, além de habilidades técnicas (planejar, direcionar e controlar o desenvolvimento de software; reconhecer armadilhas e formular um novo plano), de um bom conhecimento dos erros comuns ocorridos no gerenciamento de projetos.

Antes que um projeto de software possa ser planejado, seus objetivos e seu escopo devem ser bem estabelecidos e as restrições administrativas e técnicas devem ser identificadas em um modelo de processo de desenvolvimento de software. Muitas abordagens de modelagem são aplicadas ao processo de desenvolvimento de software. A técnica da Dinâmica de Sistemas oferece recursos para capturar todos os atributos envolvidos na dinâmica do processo de desenvolvimento de software e nos processos "soft" que desempenham importantes papéis no comportamento dos projetos de software no mundo real.

Em meados dos anos oitenta, devido à necessidade de controlar eficientemente o progressivo desenvolvimento de software, pesquisadores começaram a aplicar simulações computacionais, baseadas na modelagem dinâmica, no desenvolvimento de software, com o objetivo de entender a dinâmica do processo de produção de software. 
Os modelos dinâmicos são capazes de descrever um sistema considerando suas características dinâmicas de realimentação (feedback) e de interação entre os componentes de um processo e seus fatores "soft", ou seja, tudo o que acontece no ambiente real da organização.

Atualmente, muitas empresas de software estão se esforçando para melhorar seus processos de software conforme as diretrizes do Capability Maturity Model (CMM) ! Apesar disso, muitos desses esforços de melhoria falham porque deixam de considerar a dinâmica do processo, ignoram os fatores "soft" que desempenham importantes papéis no comportamento dos projetos de software e não preparam adequadamente os gerentes de projeto (Yourdon, 1996). Desta forma, a modelagem dinâmica qualifica-se como uma importante e eficiente abordagem capaz de representar a dinâmica do processo de desenvolvimento de software. Assim, após o desenvolvimento de um modelo dinâmico um próximo passo seria preparar adequadamente os gerentes de projeto de software.

Segundo Jones (1991) e Statz (1994), a principal causa de deficiências na gestão de projeto é a inadequação nos treinamentos e critérios de gestão utilizados. Um treinamento adequado deveria proporcionar aos gerentes um tipo de "aprendizagem organizacional". Uma modalidade interessante utilizada no ensino de conceitos organizacionais é o jogo de empresa, que por intermédio da realização de simulações é capaz de treinar eficientemente os gerentes de projeto de software. Os jogos de empresa proporcionam uma aprendizagem vivencial a seus participantes, permitindo a eles experimentar e vivenciar o processo gerencial, podendo cometer falhas catastróficas sem serem condenados, mas fazendo com que aprendam com seus erros e os evitem nas empresas reais.

\subsection{Motivação}

Existe uma clara necessidade na área de Engenharia de Software por gerentes de projeto de software eficientes. Estima-se que mais da metade de todos os projetos de desenvolvimento de software possuem custos de produção elevados devido a falhas apresentadas por gerentes de projeto (Houston, 1996). No entanto, esses custos poderiam ser minimizados se certos erros na gestão de projeto fossem evitados por intermédio de uma técnica eficiente e motivadora de treinamento e aprendizagem vivencial - o jogo de empresas. Os jogos promovem vivências, nas quais se procura trabalhar as dimensões da aprendizagem plena (Sauaia, 1998). Desta forma, o desenvolvimento de uma ferramenta que possibilite a criação e aplicação de jogos, além de propor uma aprendizagem experimental e vivencial do processo gerencial dentro da universidade, também permite investigar o desenvolvimento de jogos na área de projetos de software. Também constituiu uma motivação importante para este trabalho o desenvolvimento anterior, pelo aluno de mestrado R. E. Garcia, de uma ferramenta para a edição e simulação de modelos dinâmicos de sistemas (Garcia, 1998). Essa ferramenta, denominada Cycles, motivou e tornou viável o desenvolvimento da ferramenta para apoio a jogos de empresa.

\subsection{Objetivos}

O objetivo deste trabalho é o desenvolvimento de uma ferramenta para apoiar jogos de empresa baseados em modelos da dinâmica de sistemas. $\mathrm{O}$ trabalho envolve dois aspectos: o desenvolvimento de uma camada de software sobre a ferramenta Cycles (Garcia, 1998), de tal forma que ela possa ser usada para apoiar jogos de empresa e o desenvolvimento de

\footnotetext{
${ }^{\prime} O$ modelo de maturidade da SEI pode ser encontrado em $h$ ttp://www.sei.cmu/tecnology/cmm.html
} 
um jogo para treinamento em gestão de recursos humanos em projetos de software. $\mathrm{O}$ desenvolvimento do jogo atende a dois objetivos: servir como teste para a ferramenta a ser desenvolvida e investigar como pode ser desenvolvido um jogo para treinamento em gestão de projetos de software baseado em modelos dinâmicos de sistemas.

\subsection{Organização da Dissertação}

Esta dissertação está organizada em seis capítulos. Neste primeiro capítulo, Introdução, são apresentadas a contextualização do problema, a sua motivação e os principais objetivos pretendidos com a realização deste trabalho.

No capitulo 2, Dinâmica de Sistemas, são apresentados os estudos realizados sobre a classificação dos modelos, a metodologia e linguagens de simulação; a abordagem da teoria da Dinâmica de Sistemas e as ferramentas utilizadas na simulação de sistemas dinâmicos.

O capítulo 3 trata dos Jogos de Empresa. São apresentados nesse capitulo uma introdução (definição, histórico, classificação, etc.), a estrutura geral dos Jogos de Empresa e os principais jogos na área de gestão de projetos de software baseados na Dinâmica de Sistemas.

No capítulo 4 são apresentados o processo de adaptação e as extensões realizadas na ferramenta Cycles, a nova arquitetura desenvolvida, a modelagem conceitual, além dos aspectos do projeto da base de dados, da implementação e da interface homem-máquina da ferramenta proposta.

O capítulo 5 descreve o jogo desenvolvido e apresenta a utilização da ferramenta pelos participantes de um jogo: coordenador e equipes jogadoras durante a criação e aplicação de um jogo de empresa de gestão de recursos humanos em projetos de software.

Finalmente, no capítulo 6 são apresentadas as conclusð̃es e contribuições deste trabalho. 


\subsection{Considerações Iniciais}

A Dinâmica de Sistemas, criada no início da década de sessenta por Jay Forrester (1961) no MIT, tem despertado grande interesse nos últimos anos por ser capaz de representar, por intermédio de modelos e simulações, a dinâmica existente em uma ampla variedade de processos. Este capitulo apresenta na seção 2.2 e na seção 2.3, respectivamente, os estudos realizados sobre simulação de sistemas e sobre Dinâmica de Sistemas. Finalmente, na seção 2.4 , são apresentadas as ferramentas estudadas para edição e simulação de sistemas dinâmicos.

\subsection{Simulação}

Originalmente, o significado da palavra simulação é imitação. Este significado sugere uma importante característica da simulação: simular é imitar algo. No entanto, com o estudo realizado nesta pesquisa bibliográfica, verificou-se a existência de inúmeras definições para o conceito de simulação. O Quadro 2.1 apresenta algumas definições propostas por diferentes autores.

Quadro 2.1 - Definições de Simulação

\begin{tabular}{|l|c|}
\hline \multicolumn{1}{|c|}{ Definição } & Referência \\
\hline $\begin{array}{l}\text { X simula Y é verdade se e somente se: X e Y forem sistemas formais; Y } \\
\text { for considerado como sendo o sistema real; X for considerado como } \\
\text { sendo uma aproximação do sistema real; as regras de validade em X não } \\
\text { estiverem isentas de erro. }\end{array}$ & $\begin{array}{c}\text { Churchman apud } \\
\text { (Accioly, 1994) }\end{array}$ \\
\hline $\begin{array}{l}\text { Execução ou manipulação dinâmica de um modelo de um sistema objeto } \\
\text { com um objetivo qualquer. }\end{array}$ & $\begin{array}{c}\text { Barton apud } \\
\text { (Sauaia, 1989) }\end{array}$ \\
\hline $\begin{array}{l}\text { Um meio de se experimentar idéias e conceitos sob condições que } \\
\text { estariam além das possibilidades de se testar na prática, devido ao custo, } \\
\text { demora ou risco envolvidos. }\end{array}$ & (Martinelli, 1988) \\
\hline $\begin{array}{l}\text { Simulação é um sistema social em miniaturas; um modelo de uma } \\
\text { organização, uma nação ou um mundo - um "laboratório", no qual uma } \\
\text { ampla variedade de situações sociais pode ser reproduzida. }\end{array}$ & $\begin{array}{c}\text { Rogers apud } \\
\text { (Beppu, 1984) }\end{array}$ \\
\hline $\begin{array}{l}\text { Técnica numérica para realizar experiências em um computador digital, } \\
\text { as quais envolvem certos tipos de modelos lógicos que descrevem o } \\
\text { comportamento de um sistema econômico ou de negócios sobre extensos } \\
\text { intervalos de tempo. }\end{array}$ & $\begin{array}{c}\text { (Naylor et.al., } \\
\text { 1971) }\end{array}$ \\
\hline $\begin{array}{l}\text { Operação de um modelo que representa um sistema ou um organismo, em } \\
\text { que o modelo é passivel de manipulaçöes que seriam dificeis de levar a } \\
\text { cabo na entidade que ele representa, quer pelo preço, quer pela } \\
\text { impraticabilidade ou impossibilidade de faze-las. As propriedades } \\
\text { concementes ao comportamento de um sistema ou subsistema podem ser } \\
\text { inferidas estudando-se a operação do modelo. }\end{array}$ & $\begin{array}{c}\text { (Shubik et.al., } \\
\text { 1971) }\end{array}$ \\
\hline
\end{tabular}

Geralmente, a simulação envolve algum tipo de modelo ou uma representação simplificada de um sistema real que tenta imitar importantes elementos desse sistema. Desde o começo da história, as pessoas têm usado modelos para representar sistemas reais. Uma descrição escrita de uma batalha, uma réplica de um prédio antigo, o uso de símbolos 
para representar dinheiro, números e relações matemáticas são exemplos de modelos. Atualmente, os administradores responsáveis por importantes tomadas de decisão estão usando modelos para ajudá-los a entender o que está acontecendo e a auxiliar em suas decisões.

Dentre os diferentes tipos de modelos existentes, apenas os principais são apresentados sucintamente neste trabalho: o modelo mental, o modelo físico e o modelo matemático (Naylor et.al., 1971).

O modelo mental é aquele que representa o que alguém tem na cabeça para enfrentar determinado problema ou situação. Como este modelo é baseado nas crenças humanas, pode ser influenciado por políticas e uma ampla variedade de emoções humanas. No entanto, sua principal característica é não apresentar uma forma escrita, e em muitos casos não ser sequer expressado em alguma forma, simplesmente representa uma visão particular de alguma pessoa.

Muitas simulações são realizadas a partir de um modelo físico por meio do qual é possivel examinar propriedades dificeis de serem observadas em um sistema real. Por exemplo, pode-se construir uma miniatura de avião a fim de examinar suas propriedades aerodinâmicas, antes da construção real do avião. Entretanto, este modelo além de ser dificil de ser utilizado apresenta um custo elevado de construção.

O modelo matemático envolve símbolos matemáticos e equações para representar os relacionamentos em um sistema. Para simular um sistema representado por um modelo matemático, é necessário realizar cálculos, baseados nas equações do modelo, repetidamente. Se estes cálculos forem realizados manualmente, as simulações podem ser extremamente tediosas e caras. Durante o século XVI, muitos anos foram gastos em simulações numéricas para as experiências de navegação. Nos últimos 40 anos as simulações realizadas por computador substituíram os cálculos manuais, reduzindo espantosamente o custo dos cálculos aritméticos. Essa redução mostra que antigos problemas inviáveis e custosos de serem solucionados por simulações manuais se tornaram viáveis e econômicos.

Desta maneira, o modelo deve necessariamente considerar elementos de dois atributos conflitantes: realismo e simplicidade. Apesar de um modelo ter que representar precisamente um sistema real e seus aspectos mais importantes, ele não deve ser tão complexo que se torne impossível de compreender e manipular. $O$ modelo deve permitir ao analista determinar em que proporções uma ou mais mudanças em determinados aspectos de um sistema, que está sendo modelado, poderão afetar outros aspectos desse mesmo sistema.

Em geral, os modelos possuem quatro elementos bem definidos: componentes, variáveis, parâmetros e relações funcionais (Naylor et.al., 1971). Os componentes variam de acordo com o sistema que está sendo simulado. Por exemplo, setores primordiais como economia doméstica, negócios ou setores governamentais são usados como componentes em certos modelos macroeconômicos. As variáveis são utilizadas para relacionar um componente a outro e podem ser classificadas como variáveis exógenas, variáveis endógenas e variáveis de estado.

Variáveis exógenas são variáveis independentes ou de entrada do modelo e são previamente determinadas e fornecidas, independentemente do sistema que está sendo modelado. Estas variáveis afetam o sistema, mas não são influenciadas pelo mesmo. As variáveis exógenas podem ser classificadas como controláveis e não controláveis. As 
variáveis controláveis podem ser manipuladas por agentes responsáveis por tomadas de decisão. As variáveis não controláveis são geradas pelas circunstâncias nas quais um sistema modelado existe e não pelo próprio sistema ou pelos agentes responsáveis pelas decisōes.

As variáveis de estado descrevem o estado de um sistema ou de um de seus componentes, no início de um determinado período de tempo, no seu término ou ainda durante o decorrer de um certo período. Estas variáveis interagem tanto com as variáveis exógenas como com as variáveis endógenas do sistema, de acordo com as relações funcionais previamente estabelecidas.

Variáveis endógenas são variáveis dependentes ou de saída do sistema e são geradas pela interação das variáveis exógenas e de estado, de acordo com as características operacionais do sistema.

Parâmetros são características ou atributos do sistema que têm um único valor durante toda a simulação, mas podem mudar se alternativas diferentes forem consideradas.

Relações funcionais descrevem as interações das variáveis com os componentes de um modelo. São de dois tipos: identidades e características operacionais. Ambas são usadas para gerar o comportamento do sistema. As identidades podem tomar a forma de definições ou de proposições relativas aos componentes do modelo. Uma característica operacional é uma hipótese, geralmente uma equação matemática, que relaciona as variáveis endógenas e de estado de um sistema com suas variáveis exógenas.

Após descrever os elementos básicos que constituem a maioria dos modelos de simulação é conveniente apresentar uma classificação para estes modelos.

\subsubsection{Classificação dos Modelos de Simulação}

Os modelos de simulação podem ser classificados de diferentes maneiras. Entretanto, o sistema de classificação que parece mais apropriado para os propósitos desta dissertação é proposto por Naylor, que classifica esses modelos de simulação em determinísticos ou estocásticos; estáticos ou dinâmicos (Naylor et.al., 1971).

Nos modelos determinísticos não é permitido às variáveis exógenas e endógenas serem variáveis aleatórias com características operacionais representadas por funçōes de probabilidade. Estes modelos são menos exigentes computacionalmente que os estocásticos e podem freqüentemente ser resolvidos por técnicas como a dos máximos e mínimos.

Os modelos estocásticos são assim chamados quando pelo menos uma das características operacionais é dada por uma função de probabilidade. $\mathrm{O}$ uso da técnica analítica é muito limitado para a solução desses modelos porque eles são consideravelmente mais complexos que os modelos determinísticos. Por isso, a simulação é muito mais adequada como método de análise e solução para modelos estocásticos que para os determinísticos.

Modelos estáticos são aqueles que não levam em conta explicitamente a variação do tempo. Esses modelos são completamente determinísticos $\mathrm{e}$ as soluções podem ser normalmente obtidas por meio de técnicas analíticas diretas, tais o como cálculo de otimização e a programação matemática. 
Modelos dinâmicos são aqueles que tratam de interações variáveis com o tempo. A maioria dos sistemas interessantes e não triviais contém diversas interações sutis, porém importantes, entre os componentes do sistema, e tais interações mudam ao longo do tempo. Em um modelo dinâmico tudo está profundamente entrelaçado. Qualquer mudança em um componente do sistema pode causar impacto em outro local, pois as interações envolvem atrasos de tempo e ciclos de realimentação (feedback).

\subsubsection{Metodologia da Simulação}

Apesar de uma metodologia sistemática não ser capaz de substituir a experiência, a intuição e o conhecimento técnico de um problema, ela deve ser considerada somente como um guia e interpretada como um método dependente da criatividade, capaz de traduzir um sistema complexo em um modelo válido (Accioly, 1994).

Segundo Pritsker (Pritsker, 1986) o processo de produção e uso da simulação deve seguir as seguintes etapas:

1. formulação do problema: define o problema e o objetivo da solução. Essa formulação pode ser mais bem refinada com um entendimento mais detalhado do problema,

2. construção do modelo: abstração do problema dentro de relacionamentos lógicos e matemáticos que representam sua formulação. Para isso ser feito, o modelador deve entender a estrutura e as operações do sistema bem o suficiente para extrair seus elementos essenciais e interações sem incluir detalhes desnecessários. Somente os elementos que causam diferenças significativas na tomada de decisão devem ser incluídos,

3. aquisição de dados: identificar, especificar e coletar dados de entrada do modelo. A coleta de alguns dos dados de entrada pode ser muito custosa. Por esse motivo deve-se avaliar a sensibilidade que os resultados do modelo podem ter com a alteração de dados de entrada e determinar a melhor maneira de alocar tempo e dinheiro no refinamento desses dados,

4. tradução do modelo: programação do modelo em uma linguagem de computação,

5. verificação do programa: estabelece se o programa está funcionando corretamente. Normalmente, isso é feito por cálculos de checagem manual,

6. validação do modelo: estabelece se o modelo corresponde ao sistema real dentro dos limites esperados de exatidão. Dados de entrada, elementos do modelo, subsistemas e interfaces devem ser validados. Os modelos de simulação são freqüentemente validados por representarem os resultados de um sistema de conhecimento. Os resultados do modelo que não são validados não são úteis. Por exemplo, Hansen estudou o retrabalho em um modelo cascata simulado, mas não disse como seu modelo foi validado (Hansen, 1996),

7. projeto experimental: esse projeto tem por objetivo realizar experiências para testar eficientemente os relacionamentos envolvidos no estudo realizado e produzir o máximo de consistência nos dados de saída,

8. experimentação: executa o projeto experimental,

9. análise dos resultados: emprega métodos estatísticos para representar as inferências dos dados,

10. implementação e documentação: implementa as decisões e documenta o modelo e seu uso. 
Somando-se a esse processo, Mackulak (Mackulak, 1991) fornece algumas diretrizes para desenvolver modelos de simulação:

- é melhor minimizar detalhes na modelagem e utilizar a abordagem top-down,

- procurar os elementos mais importantes do modelo e adicionar detalhes a ele. Procurar desenvolver uma modelagem que represente os aspectos $\mathrm{e}$ os relacionamentos dos elementos mais significativos do processo,

- desenvolver um modelo capaz de representar em torno de $80 \%$ da situação real. Já que o custo de modelagem encarece rapidamente,

- conscientizar-se que a simulação apenas fornece dados para o processo de tomada de decisão e não deve tomar a decisão. Assim, o resultado da simulação não dá uma resposta, e sim uma probabilidade que deve ser representada como um intervalo confiável.

$\mathrm{Na}$ prática, um estudo não percorre as diversas etapas segundo a ordem cronológica apresentada anteriormente. Muitas etapas são executadas em paralelo e é comum o retorno a etapas anteriores. Uma das etapas que apresenta considerável dificuldade é a validação do modelo, que consiste em determinar o grau de confiança e de correção dos resultados.

O método de simulação pode ser empregado com grande sucesso como elemento auxiliar na tomada de decisões, principalmente no planejamento a médio e longo prazo, como uma ferramenta de treinamento e instrução, e em situações que envolvam custo e risco elevados. O emprego desse método permite o exame de detalhes especificos com grande precisão.

De acordo com Strack, o uso da simulação pode ser considerado quando existe uma ou mais das seguintes condições (Strack, 1984):

- não há uma formulação matemática completa para o problema,

- não há método analítico para a resolução do modelo matemático,

- a obtenção de resultados com o modelo é mais fácil de ser realizada por simulação do que por método analítico,

- não existe habilidade pessoal para a resolução do modelo matemático por técnica analítica ou numérica,

- é necessário observar o desenvolvimento do processo desde o início até os resultados finais e são necessários detalhes específicos,

- não é possível ou é muito dificil e custosa a experimentação no sistema real,

- é desejado estudar longos periodos de tempo ou são necessárias alternativas que os modelos fisicos dificilmente fornecem.

Pode-se dizer que o grau de realismo incorporado ao modelo de simulação reflete diretamente no nível de detalhamento incorporado e no custo de desenvolvimento. Considerando que várias aplicações de Jogos de Empresas fazem uso de simulações, o estudo e conhecimento de sua metodologia são de extrema importância para o projetista que irá desenvolver o modelo de um jogo. 


\subsubsection{Linguagens de Simulação}

Muitas linguagens têm sido produzidas especialmente para o desenvolvimento de simulações. Um exemplo é a linguagem DYNAMO. Embora uma simulação em computador possa ser feita utilizando uma linguagem de alto nível de propósitos gerais, as linguagens de simulação oferecem várias vantagens para o modelador (Law \& David, 1991):

- uma linguagem de simulação fornece características e recursos necessários para a simulação de um modelo,

- modelos de simulação geralmente são mais fáceis de alterar quando escritos em linguagens de simulação,

- uma linguagem de simulação permite a deteç̧ão de erros comuns na programação de modelos de simulação.

Algumas abordagens de modelagem são facilmente mapeadas por uma particular linguagem de simulação. Por exemplo, a abordagem da Dinâmica de Sistemas, de Forrester, é facilmente mapeada pela linguagem DYNAMO. Por essa razão, a abordagem de modelagem e a linguagem de simulação devem ser escolhidas e utilizadas conjuntamente.

\subsection{Introdução à Dinâmica de Sistemas}

Tratando-se de sistemas, o termo dinâmico indica uma natureza não linear de progressão, ou melhor, de evolução com o passar do tempo, dada por ciclos de realimentação de informação. Em sistemas com realimentação de informação, uma situação inicial leva à tomada de decisões que alteram o ambiente e, conseqüentemente, alteram a situação inicial de um próximo ciclo.

Assim, estendendo o conceito apresentado anteriormente, os modelos dinâmicos tratam da variação do comportamento de um sistema de qualquer natureza em função da variação do tempo, consideram a característica de realimentação existente e devem ser capaz de permitir a visualização das interdependências e dos ciclos de realimentação.

Sendo assim, o modelo dinâmico deve ser criado a partir da observação das variáveis que definem o estado de um sistema real e dos relacionamentos que governam suas mudanças sobre o tempo. Os relacionamentos são representados num sistema de equações matemáticas. Cada equação do modelo representa um elemento do sistema real.

$\mathrm{Na}$ década de sessenta Forrester propôs o conceito da Dinâmica de Sistemas com a intenção exclusiva de representar a natureza dinâmica e as características de realimentação de modelos, inicialmente aplicados às atividades industriais, tratando as interações entre fluxos de informação, ordens e materiais, dentre outras (Forrester, 1961). Apesar da estrutura proposta por Forrester representar facilmente um sistema, foi deixada de lado por longo período de tempo pela dificuldade da sua utilização. $O$ modelo original, com sua representação e suas fórmulas, era muito trabalhoso para ser simulado manualmente; mesmo com o uso de uma linguagem de programação e de computadores o modelo era dificil de ser especificado e os resultados eram dificeis de serem interpretados. Somente uma representação gráfica e estática dos relacionamentos entre os componentes do sistema não demonstra o seu comportamento dinâmico. Assim, uma animação do modelo seria necessária para visualizar o comportamento dinâmico do sistema. 
A explosão da tecnologia de computação tem causado muitas mudanças e atualmente existem computadores pessoais que facilitam a simulação instantânea de modelos interativos, em vez de sistemas com processamento por lotes, com ciclo de duração de uma semana; ferramentas de representações e animações gráficas em computadores estão sendo utilizadas. Além disso, o conceito de Dinâmica de Sistemas vem sendo aplicado a problemas relativamente menores e mais especificos do que o projeto de "modelo global" proposto por Forrester nos anos sessenta. Um exemplo de área problemática mais específica e menor é a dos processos de software abordada por Abdel-Hamid e Madnick (1991).

A notação da Dinâmica de Sistemas para a modelagem de sistemas proposta por Forrester é apresentada no Quadro 2.2. Do ponto de vista da Dinâmica de Sistemas, todos os sistemas podem ser representados em termos de níveis e taxas, com variáveis auxiliares usadas para melhor representar os relacionamentos entre niveis e taxas.

Quadro 2.2: Notaçāo da Dinâmica de Sistemas

\begin{tabular}{|c|c|}
\hline Termos & Simbolos \\
\hline Nivel & \\
\hline Taxa & \\
\hline Fluxo de informações & \\
\hline Outros fluxos & \\
\hline Constante & \\
\hline Influente - recebe influência de uma \\
variável que estó em outro diagrama
\end{tabular}

O termo nível representa um 'reservatório' que acumula fluxos ou mudanças que entram por um duto, permanecem determinados períodos de tempo dentro desse reservatório e depois saem por outro duto. Dessa forma, por analogia, pode-se pensar que nível representa um reservatório que armazena algum liquido, e o dinamismo é a variação do conteúdo do reservatório causada pela entrada e saida de fluido por dutos diferentes.

Os fluxos indicam as entradas e saidas de um nível que, por conseqüência, aumentam ou diminuem seu conteúdo. Correspondem a uma tubulação que conduz o conteúdo de um reservatório para outro. Ligados aos fluxos há as válvulas reguladoras de fluxo, chamadas de taxas. Normalmente, para especificar alguma taxa, é necessário realizar algum cálculo. Esses cálculos são armazenados em variáveis auxiliares, que fazem uso de entradas para seus cálculos e geram saídas para outras variáveis ou taxas. Um outro símbolo utilizado é a representação de constantes, que como o próprio nome diz, representam valores inalteráveis no modelo. $\mathrm{O}$ símbolo representado por uma nuvem estabelece alguma 
fronteira do modelo, ou seja, não há a preocupação com a origem ou o destino de algum fluxo que sai ou entra em uma nuvem.

E, finalmente, por causa da complexidade do modelo, pode ser necessária a divisão deste em vários diagramas ou subsistemas. Tem-se então a necessidade de se representar um "conector" entre diagramas que indica as influências (influente ou influenciado) de uma variável, que aparece em um diagrama, em elementos que se encontram em outro diagrama. Vale lembrar que, para melhor representar o estado atual de um modelo, os níveis devem receber valores correspondentes às situações iniciais, que serão alterados com o passar do tempo pelas entradas e saídas de fluxos regulados por taxas.

\subsection{Um Exemplo de Sistema Dinâmico}

Em Engenharia de Software, a Dinâmica de Sistemas pode ser aplicada nos processos de desenvolvimento de software. Baseando-se nos esforços pioneiros de Abdel-Hamid e Madnick (1991) no MIT, pesquisadores da área de melhoria de processos realizam experiências usando a Dinâmica de Sistemas para alcançar uma compreensão mais profunda de como o processo de software realmente funciona numa empresa.

Abdel-Hamid e Madnick desenvolveram um modelo que representa as atividades de gerenciamento de projetos para o caso de um projeto de desenvolvimento de software de médio porte, usando ferramentas convencionais de desenvolvimento e um processo de desenvolvimento clássico com ciclo de vida em cascata. Apesar de esse modelo não representar exatamente muitos dos projetos de hoje que usam prototipação rápida, ferramentas de desenvolvimento visual, bibliotecas de componentes reutilizáveis, etc., o trabalho de Abdel-Hamid e Madnick foi escolhido para ilustrar a aplicação da simulação no desenvolvimento de software por várias razões:

- o trabalho é a aplicação mais abrangente da simulação do desenvolvimento de software publicada na literatura,

- o trabalho apresenta descrições do modelo utilizado, como ele foi validado e as conclusões de suas experiências,

- o modelo enfatiza o gerenciamento de projeto de software, tema principal deste trabalho.

O objetivo de Abdel-Hamid e Madnick foi estudar os efeitos das políticas e ações de gerenciamento de projeto no desenvolvimento de software. Respeitando os limites do sistema, o modelo de desenvolvimento foi limitado, ignorando-se a análise de requisitos. $\mathrm{O}$ modelo inicial de gerenciamento de projetos de software foi construído baseado em entrevistas com dez gerentes de projetos de software em três grandes corporações e em extensivas revisóes da literatura de Engenharia de Software. Refinamentos desse modelo foram feitas por meio de outras entrevistas mais aprofundadas com seis gerentes de projetos de software em mais três grandes corporações. Essas entrevistas serviram para completar as falhas encontradas na literatura.

O modelo resultante é formado por quatro subsistemas que descrevem as atividades de gerenciamento de recursos humanos dentro de um projeto: a produção de software, testes, controle de garantia de qualidade do projeto e planejamento do projeto. Esses subsistemas estabelecem relacionamentos e interdependências entre si da forma apresentada na Figura 2.1. Essa figura mostra como atividades de um subsistema podem influenciar as reações de atividades de outro subsistema e que, em outro momento, a influência retorna ao primeiro 
subsistema, tendo passado por um subsistema intermediário. Vale ressaltar que uma extensão à notação é introduzida nessa figura: o quadrado com cantos arredondados representa um subsistema. Assim, como pode ser observado na Figura 2.1, cada subsistema afeta e é afetado pelos outros.

Neste trabalho optou-se por escolher apenas um dos subsistemas apresentados na Figura 2.1, o subsistema de Gerenciamento de Recursos Humanos, devido ao fato de o sistema como um todo ser muito complexo. Portanto, apenas este subsistema será apresentado em detalhes como exemplo de um sistema dinâmico.

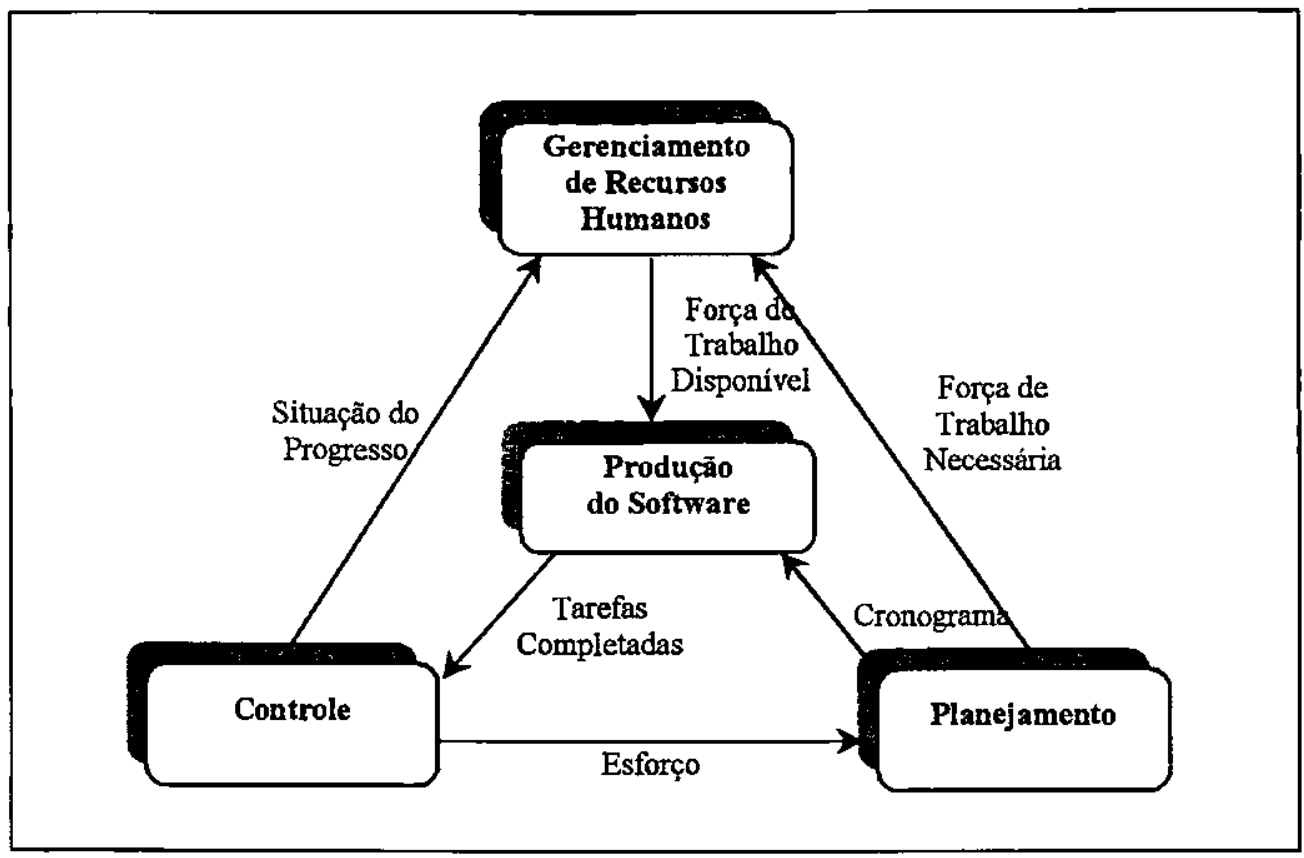

Figura 2.1-Subsistemas do Projeto de Software (Abdel-Hamid \& Madnick, 1991)

Conforme é mostrado pela Figura 2.1, o subsistema de Gerenciamento de Recursos Humanos, que compreende contratar, treinar, avaliar a assimilação e transferir recursos humanos entre projetos, é "influenciado" pelo resultado do subsistema de Planejamento e, por sua vez, "influencia" o subsistema de Produção. A variável influente Força de Trabalho Necessária, que tem origem no subsistema de Planejamento, exerce influência no subsistema de Gerenciamento de Recursos Humanos e este exerce influência no subsistema de Produção de Software por meio da variável Força de Trabalho Disponível. A Figura 2.2 apresenta a modelagem detalhada para o subsistema de Gerenciamento de Recursos Humanos.

De acordo com Abdel-Hamid e Madnick, um gerente de projetos de software pode classificar os membros da equipe de desenvolvimento em "Novatos" e "Experientes" (Abdel-Hamid \& Madnick, 1991). A distinção é justificada pela diferença de produtividade entre eles, seja por aspectos técnicos ou sociais. O dinamismo do processo de gerenciamento de recursos humanos envolve a contratação de novas pessoas, a promoção de novatos a experientes quando eles se tornam experientes, o eventual desligamento de experientes quando eles saem por qualquer motivo e a transferência de membros da equipe para outro projeto, tanto de novatos como de experientes. 


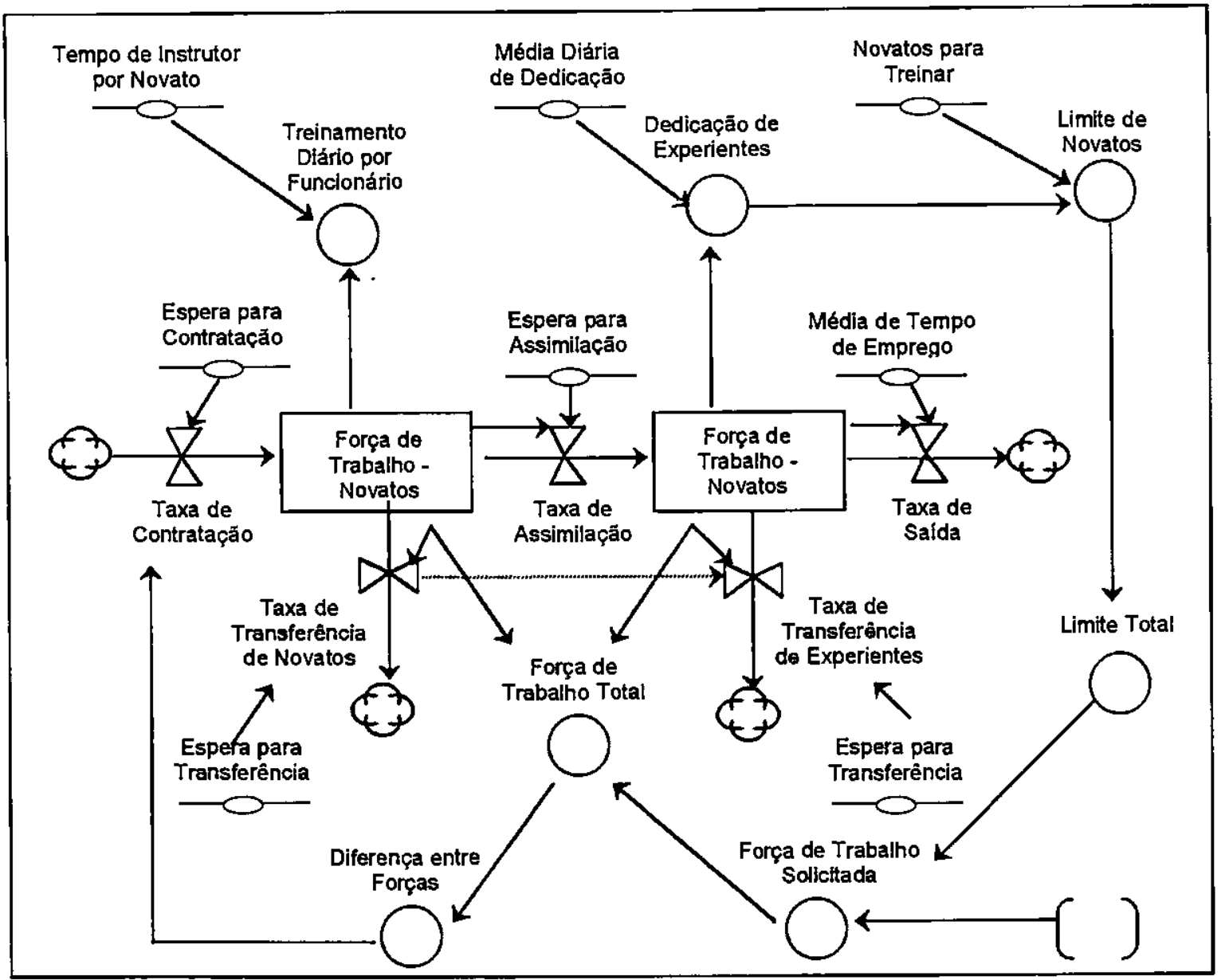

Figura 2.2 - Modelo de um Subsistema de Recursos Humanos voltado para Processos de Software (Abdel-Hamid \& Madnick, 1991)

Pode-se observar na Figura 2.2 que todos que entram em um projeto são considerados novatos, pois eles requerem treinamento considerável para familiarizar-se com a organização, hardware, software, técnicas de programação e método de projeto, dentre outros fatores. Obviamente, nem todos os recém-chegados em um projeto vêm de fora da organização, podendo ser transferidos de outro projeto e, portanto conhecem a organização e suas características. Porém entram como novatos por precisarem de um tempo para se familiarizar com o projeto, seus objetivos, seus planos de trabalho e detalhes do sistema. Nesse caso, leva-se menos tempo no aprendizado e, conseqüentemente, o custo será menor quando comparado aos novatos recrutados externamente.

Além da diferença de produtividade, outra razão para a separação entre novatos e experientes foi tentar representar o esforço extra envolvido na adição de novos membros na equipe. $O$ treinamento de recém-chegados, tanto técnico quanto social, de recémchegados é normalmente feito por membros produtivos da equipe, causando um impacto no custo, pois segundo Bott e Canning ${ }^{1}$ esses membros produtivos têm seu tempo dispensado à produção diminuído. $\mathrm{Na}$ constante Tempo de Instrutor por Novato é estabelecido um valor médio de consumo de tempo para instrução, ou seja, o tempo médio que um experiente (Força de Trabalho - Experientes) gasta para treinar um novato (Força de Trabalho - Novatos). Este valor é utilizado na variável Treinamento Diário por Funcionário para limitar o tempo dedicado à produção no subsistema de Desenvolvimento.

\footnotetext{
' Canning, R. G. Progress in Project Management, EDP Analyser, 1977, apud Abdel-Hamid \& Madnick (1991).
} 
Em uma organização, um desenvolvedor pode trabalhar em mais de um projeto simultaneamente, por isso a Média Diária de Dedicação foi introduzida no modelo e é utilizada no cálculo do tempo real de dedicação ao projeto, representado pela variável Dedicação de Experientes. Em Máximo de Novatos para Treinar tem-se um valor estabelecido como máximo de novatos a serem treinados por experiente e pela multiplicação com a Dedicação de Experientes tem-se o Limite de Novatos. A soma algébrica entre Força de Trabalho - Experientes e o Limite de Novatos gera o Limite Total, que representa o número máximo de empregados desejados no projeto. À Força de Trabalho Solicitada é atribuído o menor valor entre Limite Total e Força de Trabalho Necessária, que foi estabelecido no subsistema de planejamento. A Diferença entre as Forças estabelece a necessidade ou não de contratações, que é indicada pela diferença entre a Força de Trabalho Total e a Força de Trabalho Solicitada, que influenciará na Taxa de Contratação de novos empregados para o projeto em questão.

Deve-se notar que "contratar" pode significar a entrada de um novato pela transferência de outro projeto dentro da mesma organização. A Tabela 2.1 complementa a especificação do modelo da Figura 2.2.

É importante ressaltar que o modelo pode ser discutido sem nenhum aspecto de dinamismo e que o caso apresentado acima representa apenas um modelo do gerenciamento de recursos humanos. No ambiente do mundo real pode-se imaginar que um modo apropriado está sendo aplicado para descrever a taxa de assimilação ou a taxa de saida de elementos da equipe de desenvolvimento. Por exemplo, uma distribuição normal pode ser gerada a partir de um estudo prévio do comportamento da organização, se é que esse estudo pode ser feito. Porém, algumas taxas são obtidas de forma direta, como é o caso do tempo para contratação de um novo elemento para a equipe (Yourdon, 1996).

Tabela 2.1- Valores Iniciais e Expressōes do Modelo

\begin{tabular}{|c|c|}
\hline Componentes do Modelo & Fórmulas e Valores Iniciais \\
\hline Tempo de Instrutor por Novato & 0.20 \\
\hline Média Diária de Dedicaçăo & 1 \\
\hline Máximo de Novatos para Treinar & 1 \\
\hline Espera para Contrataçāo & 45 dias (1.5 mês) \\
\hline Média de Espera para Assimilação & 80 dias ( 2.67 meses) \\
\hline Média de Tempo de Emprego & 36 meses \\
\hline Espera de Transferência & 45 dias (1.5 mês) \\
\hline Treinamento Diário por Funcionário & Força de Trabalho Novatos * Tempo de Instrutor por Novato \\
\hline Dedicaçāo de Experientes & Média Diária de Dedicação * Força de Trabalho Experientes \\
\hline Limite de Novatos & Dedicação de Experientes * Máximo de Novatos para Treinar \\
\hline Força de Trabalho Total & Força de Trabalho Novatos + Força de Trabalho Experientes \\
\hline Limite Total & Força de Trabalho Experientes + Limite de Novatos \\
\hline Força de Trabalho Solicitada & Minimo entre Limite Total e Força de Trabalho Necessária \\
\hline Diferença entre Forças & Força de Trabalho Solicitada - Força de Trabalho Total \\
\hline Taxa de Contrataçăo & Máximo (0, Diferença entre Forças / Espera para Contratação) \\
\hline Taxa de Assimilação & Força de Trabalho Novatos / Média de Espera para Assimilação \\
\hline Taxa de Saida & Força de Trabalho Experientes / Média de Tempo de Emprego \\
\hline Taxa de Transferência de Novatos & $\begin{array}{l}\text { Minímo (Máximo (0, (-Diferença entre Forças l Espera para } \\
\text { Transferência)), Força de Trabalho Novatos) }\end{array}$ \\
\hline \begin{tabular}{lll|} 
Taxa de & Transferência de \\
Experientes & & \\
\end{tabular} & $\begin{array}{l}\text { Minimo (Força de Trabalho Experientes, (Máximo(0, -Diferença entre } \\
\text { Forcas / Espera para Transferência))- Taxa Transferência de Novatos)) }\end{array}$ \\
\hline Força de Trabalho - Novatos & 10 \\
\hline Força de Trabalho - Experientes & 15 \\
\hline Força de Trabalho Necessária & 25 \\
\hline
\end{tabular}




\subsection{Ferramentas para Edição e Simulação de Sistemas Dinâmicos}

A primeira ferramenta desenvolvida para simulação de sistemas dinâmicos foi proposta juntamente com o modelo da Dinâmica de Sistemas. Trata-se de um compilador de propósito especial chamado DYNAMO, que gera código executável para modelos de sistemas dinâmicos. Esse compilador foi con:truído para ser utilizado em um IBM 704, baseado em FORTRAN.

O compilador DYNAMO utiliza um código fonte com estrutura própria, no qual são expressas as equações do modelo. Esse código é checado para detectar algum erro de sintaxe, erros lógicos que representam inconsistências, detalhes impróprios na estrutura das equações; e fornecer, no final da compilação, um resumo da análise feita. Caso não seja encontrado nenhum problema, o compilador gera o código executável. Como resultado tem-se uma tabela contendo os valores assumidos pelas variáveis das equações definidas no código fonte, em função de uma variação temporal, e um gráfico impresso expressando tal comportamento. $O$ gráfico era impresso utilizando-se uma combinação de letras, cada uma representando uma variável.

Apesar do compilador DYNAMO realizar a simulação do comportamento de um sistema dinâmico, seja qual for sua natureza, não é possível utilizá-lo para visualizar a dinâmica dos sistemas. Isso devido à falta de recursos da época, que não suportavam a construção visual de um modelo utilizando a notação proposta por Forrester.

Com a evolução tecnológica houve a possibilidade de se desenvolver ferramentas capazes de expressar em um modelo visual a dinâmica dos sistemas. Assim, surgiram as ferramentas Stella, iThink, Vensim, Powersim e Cycles. Todas essas ferramentas são destinadas a apoiar a construção e teste de modelos dinâmicos baseados na teoria da Dinâmica de Sistemas. São ferramentas visuais que partem de um modelo gráfico com definições de comportamento expressas por fórmulas e chegam à simulação do modelo, que pode ser acompanhada em tabelas e gráficos. Um esboço de suas estruturas é mostrado na Figura 2.3. Para o desenvolvimento deste trabalho foram estudadas apenas as ferramentas Stella e Cycles.

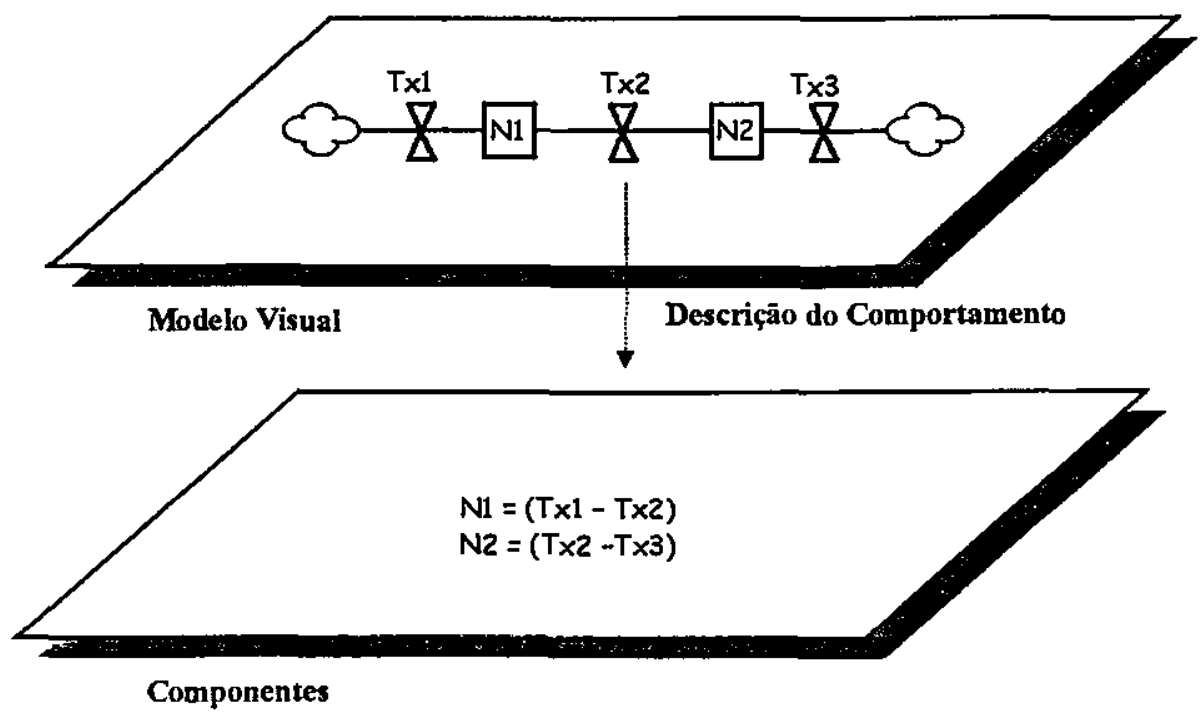

Figura 2.3 - Estrutura geral das ferramentas 
A ferramenta Stella foi desenvolvida pela HPS - High Performance Systems ${ }^{2}$ Inc., fundada em 1985 por Barry Richmond, um professor da Dartmouth College, que utilizou, na época, a revolucionária interface Macintosh para desenvolver essa ferramenta voltada a usuários comerciais da área de gerenciamento.

Nota-se que essa ferramenta pode ser considerada uma "extensão" do DYNAMO, pois o suporte gráfico tem por objetivo facilitar a construção e visualização do modelo, porém a simulação é feita através de expressões matemáticas que descrevem o comportamento dos componentes do modelo e que são validadas pelo que for definido no modelo. Os resultados obtidos na simulação são exibidos em forma de tabelas e gráficos.

A ferramenta Stella possui três camadas de modelagem. A primeira camada é reservada para um mapeamento de 'alto nível' e para a criação das interfaces de usuário. A segunda camada, camada intermediária, é destinada à 'construção do modelo'. Nesta camada é que o modelo é desenvolvido utilizando os níveis, fluxos, variáveis, taxas, etc., que juntos formarão um diagrama de fluxo do modelo. As equações são escritas durante a construção do modelo que podem ser visualizadas na terceira e última camada.

As Figura 2.4, 2.5 e 2.6 apresentam a interface das camadas apresentadas pela ferramenta Stella para um exemplo que foi implementado pela HPS.

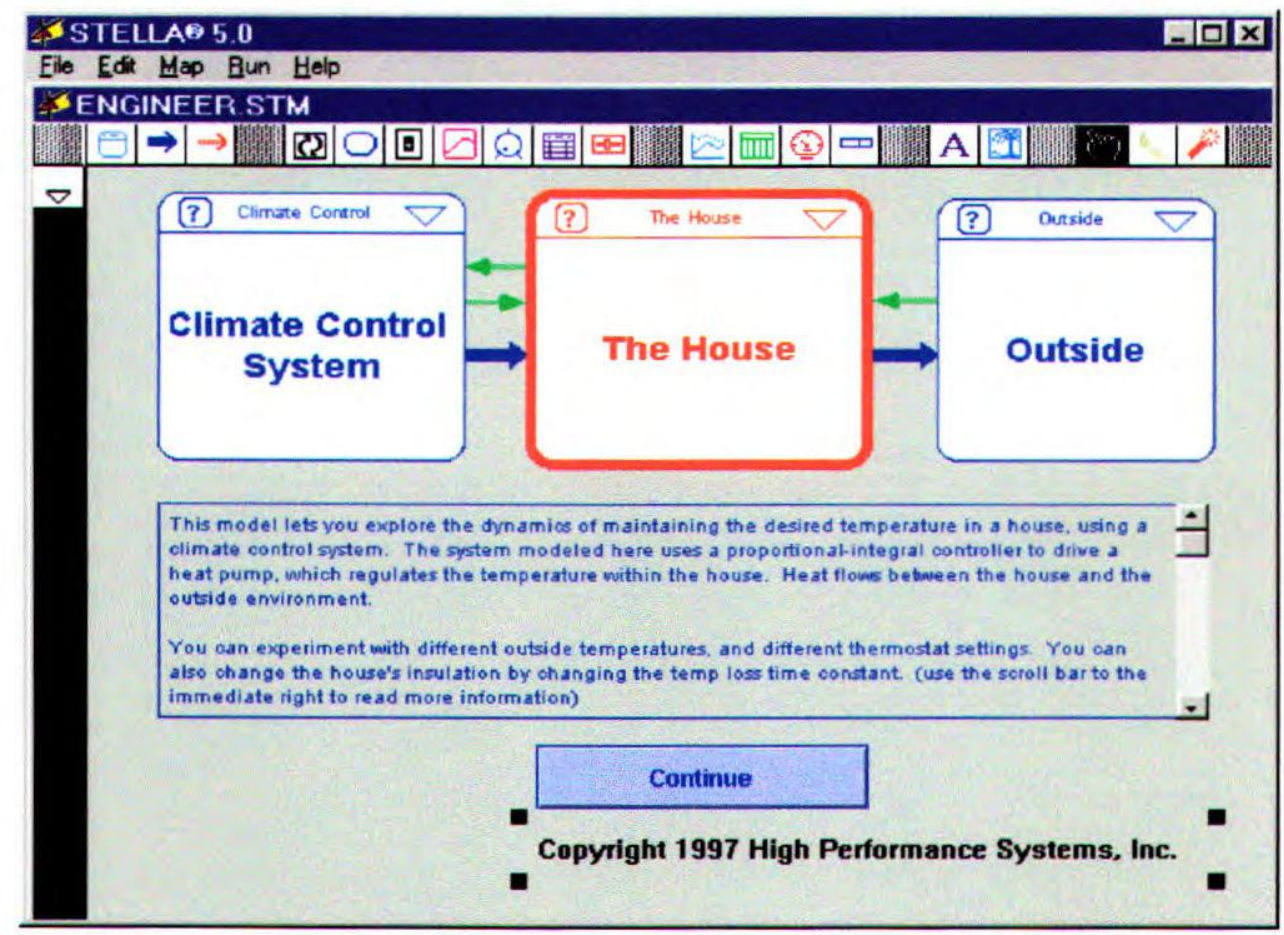

Figura 2.4 - Interface da primeira camada de modelagem do Stella

\footnotetext{
${ }^{2}$ Endereço Eletrônico: http://www.hps-inc.com
} 


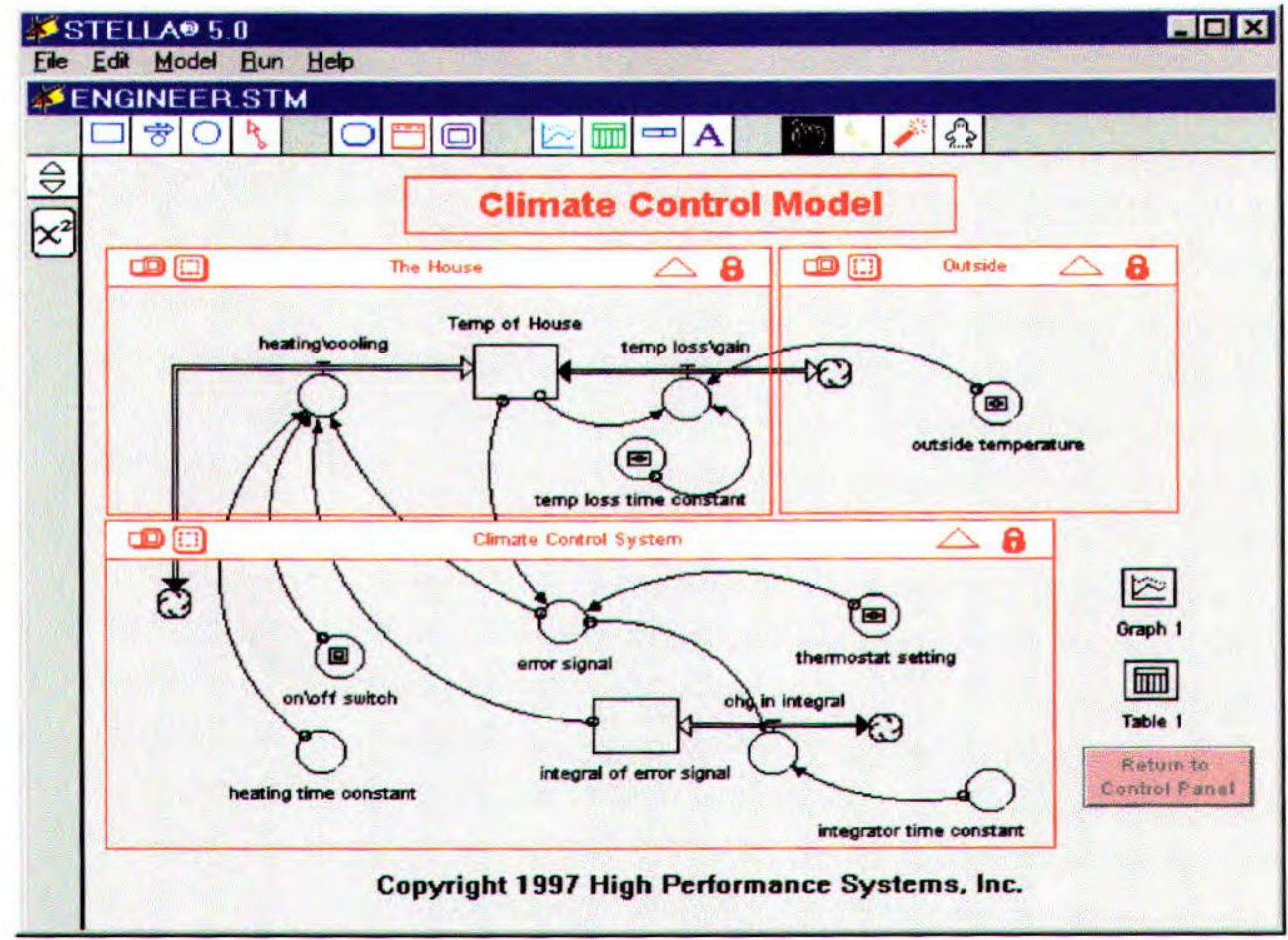

Figura 2.5 - Interface da segunda camada de modelagem do Stella

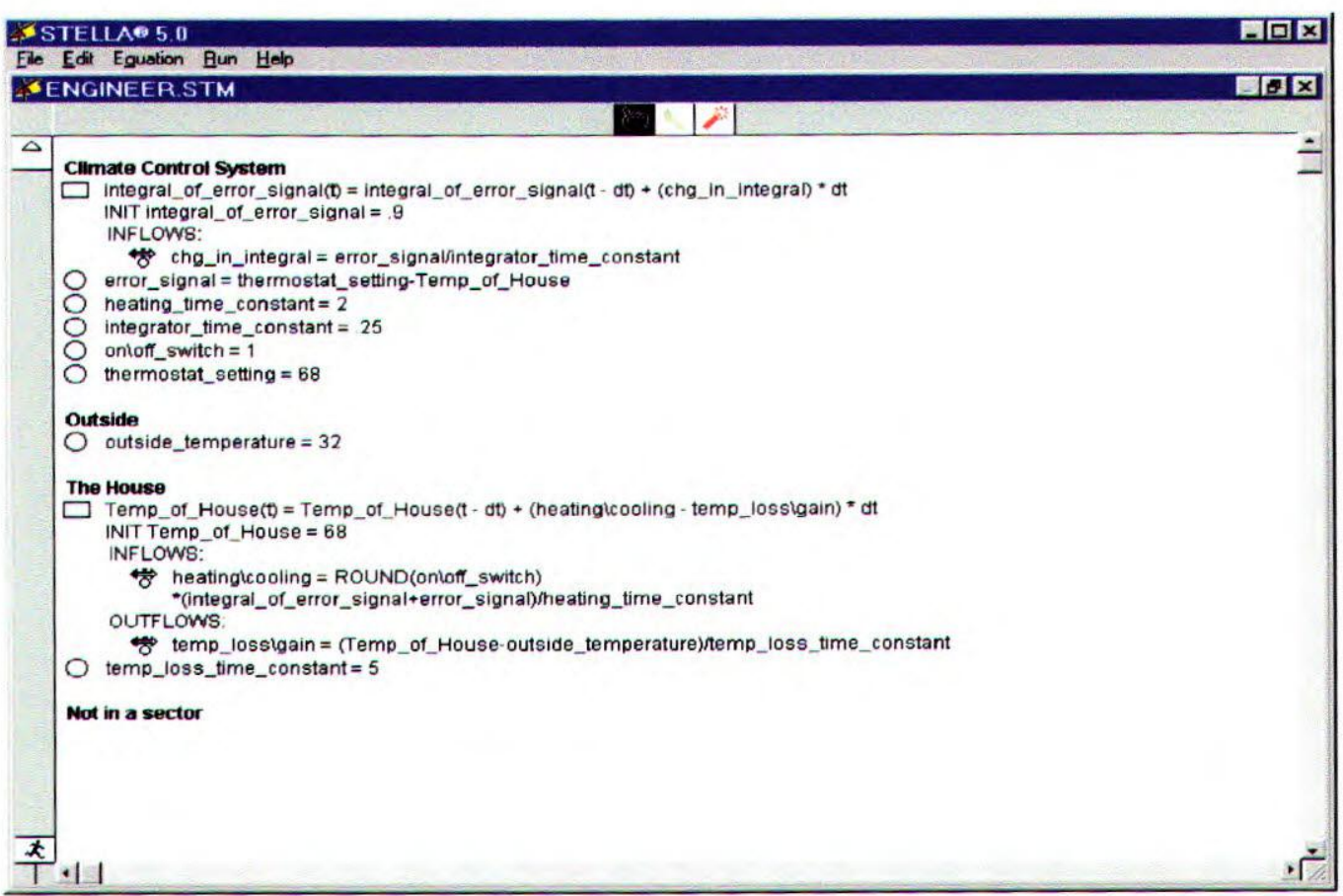

Figura 2.6 - Interface da terceira camada de modelagem do Stella - Equações

A simulação de um modelo pode ser realizada diretamente, ou seja, sem pausas por um intervalo de tempo ou então com pausas que podem ser utilizadas para alterar valores de entrada do modelo e assim causar mudanças nos resultados dos próximos intervalos. Como foi dito anteriormente, os resultados das simulações podem ser visualizados em tabelas ou gráficos. As tabelas são utilizadas para mostrar os resultados numéricos precisos 
de cada período de tempo da simulação e os gráficos são mais utilizados para visualizar qual a tendência dos resultados da simulação.

Também para apoiar a edição e a simulação de sistemas dinâmicos foi desenvolvida a ferramenta Cycles, utilizando o ambiente $\mathrm{C}++$ Builder para ser executada em microcomputadores (Garcia, 1998). Esta ferramenta também possui uma interface gráfica que permite a edição do modelo. Assim como a ferramenta Stella apresentada anteriormente, a ferramenta Cycles permite a edição de um modelo visual, que é baseado em expressões matemáticas capazes de descrever o comportamento dos componentes do sistema. Os resultados da simulação são organizados em forma de tabelas e gráficos, facilitando a visualização. A arquitetura da ferramenta Cycles é apresentada na Figura 2.7.

A ferramenta Cycles apresenta dois níveis de modelagem. O primeiro nível é destinado à modelagem dos subsistemas e seus inter-relacionamentos. O segundo nível é utilizado para a edição de cada subsistema criado. Dentro dos subsistemas são criados os níveis, taxas e outros elementos para modelar o comportamento do respectivo subsistema.

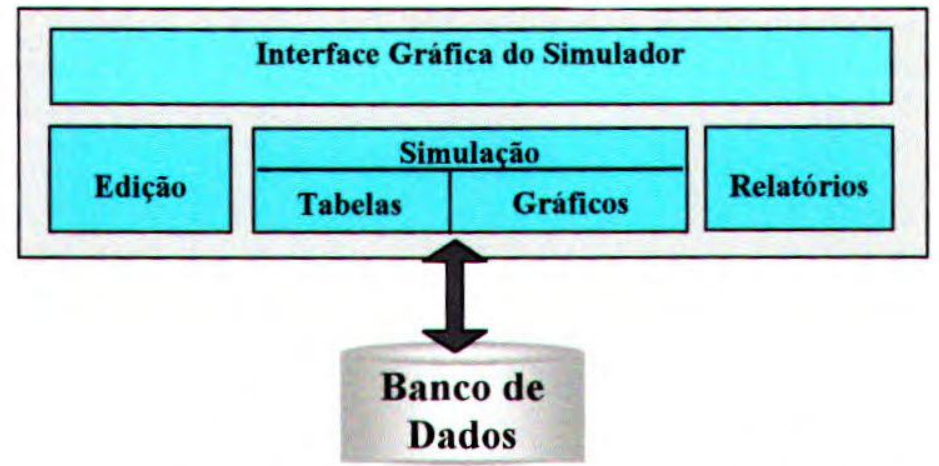

Figura 2.7 - Arquitetura da Ferramenta Cycles

A interface da ferramenta é exibida na Figura 2.8 em seu primeiro nível de modelagem, no qual apenas subsistemas e suas influências são permitidos.

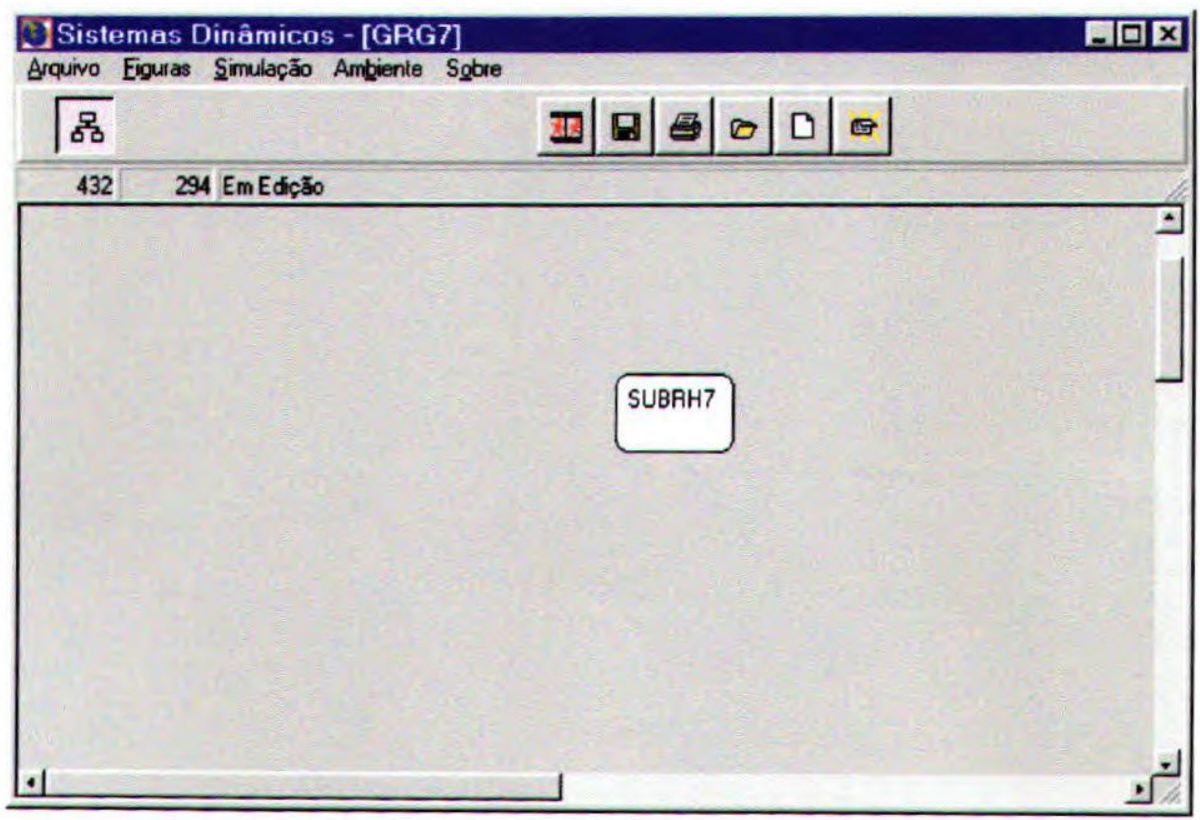

Figura 2.8 - Interface da Ferramenta Cycles 
A Figura 2.9 apresenta um exemplo de modelagem de um subsistema - subsistema de Gerenciamento de Recursos Humanos.

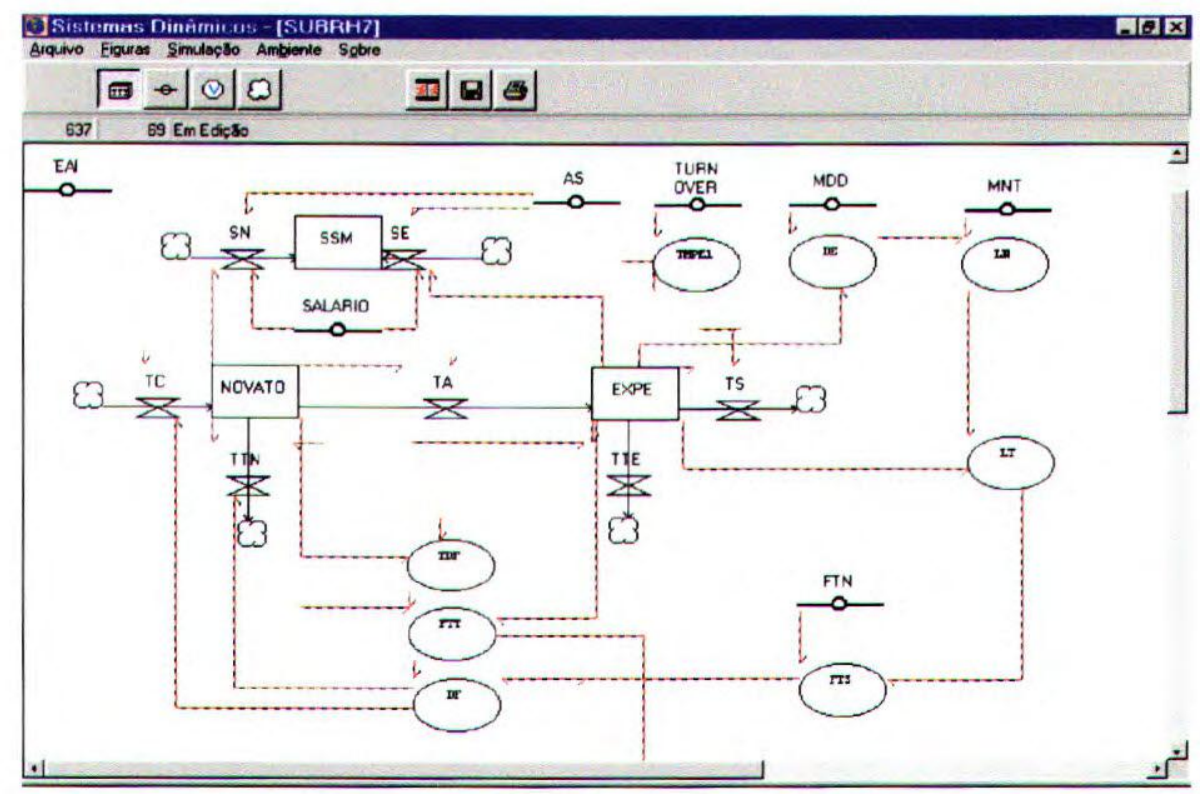

Figura 2.9- Modelo de um Subsistema de Recursos Humanos voltado para Processos de Software (Abdel-Hamid \& Madnick, 1991) em Edição

A ferramenta dispõe de uma interface na qual são estabelecidos parâmetros para a simulação, tais como o período de simulação, que representa o número de repetições da simulação e a unidade de tempo da simulação (dia, mês, trimestre, semestre, ano, etc.). $\mathrm{O}$ modelo pode ser salvo e recuperado em uma base de dados.

Durante o processo de criação do modelo é de extrema importância o conhecimento do sistema, com dados históricos para tornar o modelo mais próximo da realidade. A utilização de estimativas infundadas é catastrófica para a simulação. Portanto, formalizações do processo de software, que permitem a recuperação de registros históricos, são muito úteis para um melhor conhecimento do sistema estudado.

Para dar início à simulação é necessário realizar antes uma validação do modelo, verificando sua consistência e integridade, pois na edição (definição do modelo) a ferramenta permite que o modelo mantenha algumas inconsistências e que operações incorretas sejam executadas com o modelo incompleto. Este processo de validação é denominado de pré-simulação.

Assim, após a pré-simulação pode-se realizar a simulação por um período de tempo e obter os resultados organizados em uma tabela e um gráfico com os elementos desejados, como mostra a Figura 2.10.

Visualizando o comportamento do sistema modelado, o responsável pelo projeto pode analisar seu comportamento, identificando pontos que são passíveis de alteração e antes de tomar alguma decisão pode simular a reação do sistema diante dessas alterações. 


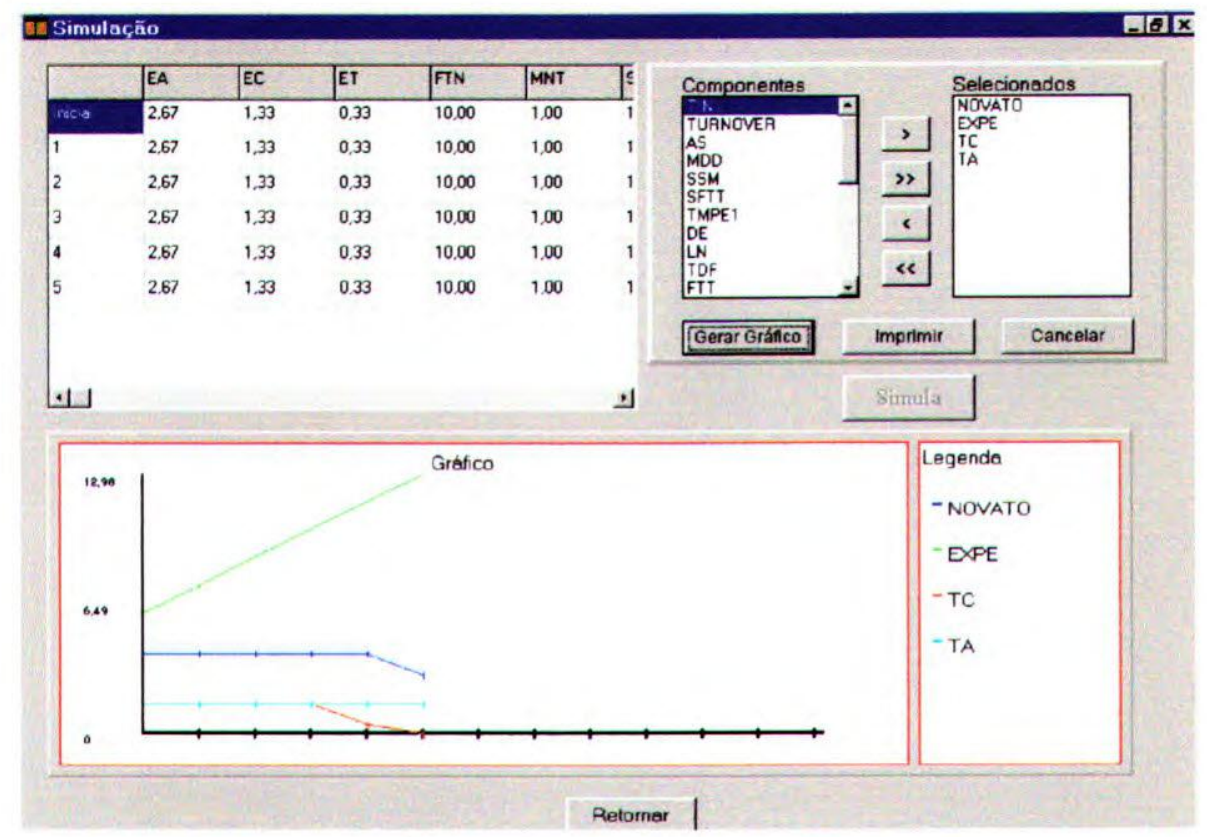

Figura 2.10-Simulação do Sistema

\subsection{Considerações Finais}

Neste capítulo foram apresentados o conceito da Dinâmica de Sistemas e sua importância na representação, por meio de modelos e simulações, da dinâmica existente em muitos processos. Também foram apresentadas algumas ferramentas de simulação de sistemas dinâmicos capazes de auxiliar gerentes na tomada de decisões.

Baseando-se neste estudo, no próximo capítulo são apresentados o conceito de Jogos de Empresas e sua importância no treinamento de gerentes em técnicas de gestão e tomada de decisão, a partir de simulações baseadas em sistemas dinâmicos. 
Capitulo 3

Jogos de Empresa 


\subsection{Considerações Iniciais}

Nos últimos tempos, a globalização da economia e o avanço tecnológico, visando uma competitividade globalizada, têm gerado uma busca crescente por um modelo de competência gerencial (Sæuaia, 1997). Esse novo contexto tem despertado grande interesse do ambiente empresarial e consequentemente, do ambiente acadêmico, por uma eficiente educação gerencial.

Desta forma, o estudo e a utilização, no meio acadêmico, de novos métodos e técnicas que propiciem uma aprendizagem vivencial têm-se tornado necessários. Os Jogos de Empresas que promovem vivências e são destinados à formação, treinamento e desenvolvimento de gerentes têm desempenhado importante papel nesse processo de aprendizagem.

A seção 3.2 apresenta uma introdução aos Jogos de Empresa, a seção 3.3 a estrutura dos jogos de empresa, a seção 3.4 apresenta alguns jogos de empresas na área de gestão de projetos de software e na seção3.5 são apresentadas as considerações finais.

\subsection{Introdução aos Jogos de Empresas}

O jogo é uma atividade espontânea, realizada por mais de uma pessoa e regida por regras que determinam quem será o vencedor. Estas regras representam todas as características de um jogo, tais como: o tempo de duração, o que é permitido e proibido, valores das jogadas e indicações sobre como terminar a partida.

Antes de ser apenas uma atividade lúdica, o jogo é em geral um instrumento dos mais importantes. Por meio deles as pessoas revelam caracteristicas de sua personalidade que normalmente não exibem por temer reprovações. Devido ao ambiente permissivo, as vivências são espontâneas e surgem comportamentos dissertivos ou não-assertivos, trabalhados por meio de uma análise após o término do jogo. As conclusões servem de base para reformulações ou reforço de atitudes e comportamentos.

Segundo Elgood ${ }^{1}$, um jogo deve apresentar as seguintes características:

- ter uma estrutura evidente, de modo a poder ser reconhecido como o mesmo, sempre que for utilizado;

- colocar os participantes em confronto com situações de mudança, sendo estas total ou parcialmente provocadas por suas próprias ações;

- permitir a identificação antecipada de algum critério de avaliação do vencedor;

- exigir uma certa quantidade de dados, documentos e materiais, administrativos ou comportamentais.

Derivados dos jogos puramente lúdicos, cujo propósito se resume em entreter pessoas, muitos outros jogos têm sido desenvolvidos e aplicados em diversas áreas: Militar, Ciências do Comportamento, Contabilidade, Economia, Administração, Educação, etc (Cohen \& Rhemman, 1961). Em especial, destacam-se os jogos educacionais utilizados com a finalidade de proporcionar uma aprendizagem orientada. Dentre esses jogos educacionais e suas mais variadas aplicações no campo da educação, existem os Jogos de

\footnotetext{
'Elgood, Chris Manual de Jogos de Treinamento, São Paulo: SIAMAR, 1987 apud Sauaia (1989)
} 
Empresas, principal interesse de estudo deste trabalho, cuja aplicação específica vem ocorrendo na área gerencial.

Os Jogos de Empresas vêm sendo utilizados na formação, treinamento e desenvolvimento de habilidades gerenciais de profissionais cuja função de gerenciamento é fundamental em suas atividades de trabalho. Eles simulam um cenário empresarial dinâmico capaz de oferecer uma visão global ou sistêmica do funcionamento do ambiente gerencial e de sua dinâmica organizacional, que permite a seus participantes iáentificar, analisar e propor soluções a problemas de empresas fictícias.

Existem várias definições para os Jogos de Empresas, segundo diferentes enfoques e guiados por diferentes objetivos. O Quadro 3.1 apresenta algumas dessas definições.

Quadro 3.1- Definiçōes de Jogos de Empresas

\begin{tabular}{|c|c|}
\hline Definição & Referẽncia \\
\hline $\begin{array}{l}\text { Um exercício sequencial de tomada de decisões, estruturado em tomo de } \\
\text { um modelo de uma situação empresarial na qual os participantes se } \\
\text { encarregam da tarefa de administrar as empresas simuladas. }\end{array}$ & $\begin{array}{l}\text { Thorelli \& Graves } \\
\text { apud (Sauaia, } \\
\text { 1989) }\end{array}$ \\
\hline $\begin{array}{l}\text { Um exercício em que, num dado contexto empresarial, tomam-se decisões } \\
\text { econômicas válidas para um periodo de tempo fixado, são informados os } \\
\text { resultados dessas decisões e então tomam-se novas decisões para o periodo } \\
\text { de tempo subseqüente. }\end{array}$ & $\begin{array}{l}\text { Zoll apud (Sauaia, } \\
\text { 1989) }\end{array}$ \\
\hline $\begin{array}{l}\text { Uma técnica ou veículo de ensino que faz uso de situações especialmente } \\
\text { projetadas para representar as reais condições ambientais do mundo dos } \\
\text { negócios. }\end{array}$ & $\begin{array}{l}\text { Carlson apud } \\
\text { (Sauaia, 1989) }\end{array}$ \\
\hline $\begin{array}{l}\text { Um exercicio seqüencial de tomada de decisões, estruturado sobre um } \\
\text { modelo de uma operação empresarial, em que os participantes assumem o } \\
\text { papel de gerentes da operação simulada. }\end{array}$ & $\begin{array}{l}\text { Shimizu apud } \\
\text { (Sauaia, 1989) }\end{array}$ \\
\hline $\begin{array}{l}\text { Um Jogo de Empresa é aquele em que a maioria das funções de uma } \\
\text { empresa é simulada mas os participantes se ocupam apenas da operação } \\
\text { intema. }\end{array}$ & $\left(\right.$ Elgood $\left.^{2}, 1987\right)$ \\
\hline $\begin{array}{l}\text { Abstraçōes matemáticas simplificadas de uma situação relacionada com o } \\
\text { mundo dos negócios. Os participantes do jogo, cada um, individualmente } \\
\text { ou em grupo, administram a firma como um todo ou uma parte dela através } \\
\text { de decisões administrativas, por períodos sucessivos e seqüenciais. }\end{array}$ & (Beppu, 1984) \\
\hline $\begin{array}{l}\text { Uma seqüência de tomada de decisões que determinam mutações no estado } \\
\text { patrimonial das empresas fictícias, à luz das quais os participantes tomam } \\
\text { novas decisões, repetindo um ciclo por um certo número de vezes. }\end{array}$ & (Tanabe, 1977) \\
\hline
\end{tabular}

Como pôde ser observado, para a maioria dos autores, um Jogo de Empresa simula um contexto empresarial e nesse contexto equipes tomam decisões válidas para um período de tempo pré-fixado. Os resultados dessas decisões são informados aos jogadores, que então tomam decisões para os periodos seguintes. Assim, os Jogos de Empresa são abstrações matemáticas simplificadas de uma situação relacionada com a gestão de negócios ou de administração de partes do negócio, como a produção e o desenvolvimento de sistemas de informação.

\footnotetext{
${ }^{2}$ Elgood, Chris Manual de Jogos de Treinamento, São Paulo: SIAMAR, 1987 apud Tanabe (1977)
} 
No Jogo de Empresa faz-se um exercício de tomada de decisão com base no modelo de um cenário empresarial. O resultado de uma tomada de decisão baseia-se na "execução do modelo", ou seja, sua simulação. Nada impede, entretanto, que para a tomada de uma decisão em particular, os jogadores façam simulações de problemas em particular.

Embora existam inúmeros jogos de empresas, é possível abstrair algumas características gerais presentes nesses jogos, tais como (Accioly, 1994):

- simplificar parte do mundo real por intermédio da elaboração de um modelo;

- expressar no modelo as características do ambiente sob forma de relações lógicas ou matemáticas, apresentando algumas relações completamente conhecidas pelos participantes enquanto que outras, especificamente as que envolvem variáveis representativas de comportamento, só são reveladas de modo vago e quantitativo;

- apresentar um ambiente simulado que substitui os elementos do sistema real, para possibilitar a apuração dos resultados e o retorno aos participantes das conseqüências de suas decisões;

- promover a repetitiva interação entre os participantes e o modelo;

\subsubsection{Histórico}

A origem exata dos jogos - local e época - provoca ainda hoje alguma controvérsia. Os primeiros usos que se tem notícia dos jogos foram os destinados a fins militares, desenvolvidos há milhares de anos para a avaliação de táticas e estratégias em campos de batalha reais ou imaginários que teriam ocorrido com os Jogos de Guerra na China, por volta do ano 3000 A.C., com a simulação de guerra Wei-Hai, e na Índia, com o jogo Chaturanga. O mais elaborado dentre os jogos, o New Kriegspiel, teria sido criado por George Venturini, em Schleswig, em 1798.

Muitos militares, treinados nesses Jogos de Guerra, empregaram tais conhecimentos e tecnologias na realização de funções civis de administração de negócios. Assim, tais Jogos de Guerra evoluiram para versões de Jogos Empresariais e no ano de 1955 foi desenvolvido o Rand Corporation Game Monopologs (Keys \& Wolfe, 1990), utilizado para simular o sistema de abastecimento da Força Aérea Americana e que podia ser empregado na administração de negócios em geral. Em 1956, um grupo de pesquisadores da American Management Association - AMA, adaptou a filosofia e os procedimentos adotados nos Jogos de Guerra para os negócios, desenvolvendo, desta maneira, o Top Management Decision Game - um Jogo de Empresa muito simples se comparado aos atualmente disponiveis, mas que, por suas características, deve ser considerado o primeiro Jogo de Empresa. Schreiber teria aplicado, em 1957, na Universidade de Washington, o primeiro jogo para um público estudantil (Keys \& Wolfe, 1990).

Durante a Segunda Guerra Mundial, quando muitos pilotos deviam ser treinados de maneira rápida e eficiente, os simuladores foram largamente utilizados. "Oficiais inexperientes podiam pilotar, aprender e decolar, orientar-se no ar, fazer manobras durante o vôo, pousar e até mesmo sofrer inúmeros acidentes fatais, e depois ainda voltar a voar. Economizaram-se milhões de dólares e inúmeras vidas humanas..." (Wells, 1990).

O mesmo ocorre com os Jogos de Empresas ou Jogos de Negócios, em que pequenos negócios ou empresas podem ser simulados colocando-se em seu gerenciamento aprendizes que experimentam e vivenciam o processo gerencial, podendo cometer falhas graves sem acarretar prejuizos reais e fazendo com que aprendam com seus erros e os 
evitem nas empresas reais (Sauaia, 1997). Segundo Wells (1990) os simuladores de vôo ganharam importância com o passar do tempo, tornaram-se mais sofisticados com o desenvolvimento dos computadores e passaram a reproduzir aeronaves comerciais muito maiores do que os aviões militares. As simulações empresariais, que ganharam importância desde os anos 50 e migraram dos computadores de grande porte para os computadores pessoais, tornando-se mais velozes, ágeis e fáceis de operar, juntamente com 0 desenvolvimento de modelos mais completos e mais próximos da realidade, foram as principais ferramentas disponibilizadas para o aperfeiçoamento dos Jogos de Empresas.

Atualmente, as empresas estão se conscientizando da importância da aplicação desta nova tecnologia para o aperfeiçoamento de seus Recursos Humanos, principalmente, daqueles responsáveis por importantes tomadas de decisão. Interessadas em jogos mais específicos, que exigem modelos mais sofisticados e com maior quantidade de cálculos, propiciaram uma verdadeira explosão no desenvolvimento desta tecnologia e um conseqü ente aumento do uso dos Jogos Empresariais (Wilhelm, 1997). Especialmente nos Estados Unidos, que apresentam dados registrados dessa explosão, pesquisas informam que no ano de 1961 mais de 100 jogos foram desenvolvidos no meio acadêmico, o que permitiu o treinamento de mais de 30.000 executivos. Em 1980 estavam sendo explorados mais de 1.500 Jogos Empresariais para o treinamento em universidades e empresas (Keys \& Wolfe, 1990).

\subsubsection{Classificação}

Os Jogos de Empresas podem ser classificados de diversas maneiras, segundo: a sua complexidade; os meios utilizados para interpretação, armazenamento, processamento e análise dos dados de entrada, e a época em que foram desenvolvidos.

Dentre os jogos classificados de acordo com a complexidade existem aqueles mais simples e diretos e aqueles mais completos. Nos jogos simples e diretos a preocupação central é o descobrimento de cenários e ambientes em que uma determinada empresa esta inserida. Estes jogos são destinados a estimular os jogadores a explorarem os pontos fortes e fracos da organização. Os jogos mais completos e complexos, também chamados de Jogos Empresariais Master, exploram um grande volume de dados e decisões de uma empresa como um todo e do ambiente em que ela está inserida. Estes jogos exigem um elevado grau de conhecimento e são destinados a desenvolver as habilidades na tomada de decisões que proporcionem um melhor posicionamento da empresa na competição com as demais, respeitando-se as limitações e características existentes no ambiente.

Os jogos também poder ser classificados de acordo com os meios utilizados para interpretação, armazenamento, processamento e análise dos dados de entrada. Seguindo esta classificação os jogos podem ser Manuais ou Computadorizados. Os Jogos Manuais são similares aos Jogos de Guerra utilizados até a década de setenta. Este tipo de jogo ainda é muito utilizado e destina-se, principalmente, a explorar sentimentos e posicionamentos interpessoais dos jogadores, sendo bastante utilizados no treinamento de executivos de empresas. Os Jogos Computadorizados, atualmente os mais comentados e desenvolvidos em decorrência do conjunto de recursos disponíveis, computadores e modelos, simulam uma realidade de competição entre empresas dentro de um determinado ambiente e destinam-se a aprimorar 0 aprendizado de determinados temas ou 0 desenvolvimento de habilidades dos jogadores no emprego de certas técnicas gerenciais (Rocha, 1997). 
De acordo com a época em que foram desenvolvidos, os jogos também podem ser classificados em Jogos Antigos, Jogos de $1^{a}$ Geração e Jogos de $2^{a}$ Geração. Os Jogos Antigos baseiam-se no processamento manual de informações. Baseados nesses jogos surgiram os Jogos de $1^{\text {a }}$ Geração, que realizam o processamento de informações em computadores de grande porte. Na época em que surgiram, apenas empresas e universidades de grande porte possuíam ou tinham acesso fácil a esses meios computacionais. Eram utilizados por especialistas e seus procedimentos de processamento eram muito trabalhosos. $O$ avanço tecnológico que possibilitou o desenvolvimento de computadores pessoais; a redução de custos dos equipamentos e o desenvolvimento de sistemas operacionais e linguagens de programação mais amigáveis favoreceu o surgimento dos Jogos de $2^{a}$ Geração, sendo estes, muitas vezes, uma adequação dos Jogos de $1^{a}$ Geração ao uso de microcomputadores. Foram estes jogos que permitiram a verdadeira explosão do desenvolvimento desta tecnologia e sua utilização nos ambientes acadêmico e empresarial. Atualmente, tem-se observado a tendência de desenvolvimento dos denominados Jogos de $3^{a}$ Geração, que devem permitir: interatividade, ambientes gráficos amigáveis, simulação de cenários e sistemas de diagnóstico, e resolução de problemas com base nos elementos da inteligência artificial (Wilhelm, 1997).

Os jogos também podem ser classificados quanto ao grau de interação entre as decisões da equipe, podendo ser interativos ou não interativos. Nos jogos interativos as decisões de uma equipe afetam as decisões das demais e nos jogos não interativos cada equipe chega a um resultado independente, que pode ser comparado a um padrão e ao resultado das demais equipes.

Outra classificação importante refere-se às áreas funcionais abrangidas pelo modelo de simulação. Os jogos de administração geral simulam a operação de todas as áreas funcionais da empresa, de forma integrada. Os jogos funcionais simulam uma área funcional da empresa, tal como vendas ou produção, sem considerar as demais áreas. Os jogos podem considerar também sub-funções particulares dessas áreas funcionais, como a programação da produção ou a gestão de projetos de sistemas de informação.

\subsubsection{Jogos no Processo de Ensino/Aprendizagem}

Os jogos são utilizados no processo de ensino/aprendizagem como um método simulado em que o treinando é inserido em determinado ambiente, que deve ser o mais próximo possível da realidade. A principal característica de um Jogo de Empresa é a de explorar o lado competitivo do ser humano, que o estimula a disputar com outras pessoas com a finalidade de vencer a disputa.

Segundo Senge (1990) o melhor processo de ensino/aprendizagem é aquele que envolve uma experiência direta, por meio de tentativas e erros, em que ações são realizadas e, após uma análise das conseqüências dessas ações, são elaboradas novas ações diferentes e melhores que a anterior.

De acordo com Bowen (1987), um jogo avaliado segundo a teoria de aprendizado experimental apresenta um grande impacto neste processo, uma vez que pode ser estruturado de modo a:

- permitir uma visão holística da situação simulada, mostrando a interatividade entre os seus diversos componentes; 
- ser desenvolvido em um ambiente de grande estímulo emocional e de total segurança, uma vez que as conseqüências das decisões propostas atingem exclusivamente um modelo;

- permitir uma resposta imediata das conseqüências das decisões propostas;

- explorar uma das características da personalidade humana que é a de participar e vencer uma competição pela tomada de decisões destinadas a atingir resultados melhores do que os obtidos pelos demais competidores.

Por outro lado, os jogos demandam um tempo muito maior quando comparados a outras metodologias de ensino adotadas no processo de ensino/aprendizagem.

Keys e Wolfe (1990) desenvolveram uma avaliação dos Jogos de Empresa no processo de ensino/aprendizagem. Pesquisas foram realizadas em Universidades dos Estados Unidos, que comprovaram suas vantagens em comparação à aplicação de Estudos de Casos e ao método tradicional de ensino, com aulas expositivas. Vantagens também foram observadas no ensino de processos gerenciais em geral, exercendo um importante treinamento profissional do aluno submetido a este processo de aprendizagem.

Entretanto, algumas desvantagens da aplicação dos Jogos de Empresa foram encontradas em algumas pesquisas citadas pelos autores. Os fatores que contribuem fortemente para o sucesso ou insucesso da aplicação desse método são: a atuação do coordenador, as aptidões e as habilidades dos jogadores e das características intrínsecas do modelo empregado para simular o ambiente em que o jogo é desenvolvido. $O$ objetivo da análise feita pelos autores é o grau de aprendizado proporcionado aos alunos por diversos tipos de jogos. Nessa análise os jogos foram divididos em classes de complexidade e pôde ser concluído que em qualquer nível de complexidade há um aumento do aprendizado, sendo óbvio que, quanto mais complexo for o jogo, maior é o ganho apresentado.

Um dos aspectos essenciais na utilização de Jogos de Empresa é o que diz respeito ao ganho decorrente da discussão interna, em cada grupo, destinada a avaliar a decisão mais adequada a ser tomada em cada jogada. Em princípio, não há inconveniente algum de que cada empresa competidora seja administrada por apenas um elemento; no entanto, o tempo destinado para tomada de decisões tende a ser mais curto do que em outras situações. Mas, quando a empresa competidora é administrada por uma equipe, a troca de experiências entre seus componentes tende a consolidar os conhecimentos teóricos requeridos e proporcionar um ambiente de desenvolvimento de habilidades capazes de gerar resultados satisfatórios nas jogadas e futuramente em atividades profissionais.

Felizmente, nos dias atuais existem várias condições que contribuem para o sucesso da aplicação dos Jogos de Empresa no processo de ensino/aprendizagem e treinamento de alunos em atividades gerenciais. Essas condições são (Rocha, 1997):

- disponibilidade de computadores pessoais de grande capacidade e preços acessiveis;

- desenvolvimento de modelos de fácil compreensão e que podem ser utilizados para a simulação de ambientes específicos;

- desenvolvimento de linguagens computacionais que possibilitam o seu uso na programação desses modelos;

- difusão do uso de computadores para a solução de problemas mais variados; 
- utilização de jogos de entretenimento que exploram um ambiente real e utilizáveis em computadores pessoais.

\subsection{A Estrutura dos Jogos de Empresas}

O desenvolvimento de um jogo não pode ser resumido em uma receita padrão, principalmente ao se levar em conta a ampla diversidad a dos jogos que existem e que podem ser criados. Além disso, o principal ingrediente de um jogo é a criatividade por trás de sua criação. Entretanto, é possível fazer algumas considerações genéricas sobre o assunto para auxiliar na elaboração de um jogo para um fim especifico.

Antes de iniciar o desenvolvimento de um jogo, é importante fazer uma pesquisa dos jogos existentes com o objetivo de analisar como foram construídos e como funcionam. A pesquisa de jogos existentes é também importante para evitar o desenvolvimento de um jogo com objetivos e necessidades semelhantes a outro já disponível e que pode ser, com menor ou maior esforço, ajustado de forma a enfatizar as relações essenciais.

Os objetivos do jogo devem ser claramente explicitados aos desenvolvedores do jogo. Além disso, deve-se ter certeza de que o jogo de empresas é a metodologia mais adequada para atingir tais objetivos.

Geralmente equipes multidisciplinares ajustadas ao tipo de jogo devem participar do desenvolvimento do jogo, pelos diferentes enfoques dos jogos, pelos seus aspectos técnicos relevantes e pela criatividade necessária para resolver certos detalhes de estruturação.

Ao se criar um jogo, é importante conhecer a relação custo-beneficio de seu desenvolvimento. $O$ custo de um jogo é representado por três dimensões:

- custo de aquisição e desenvolvimento de um jogo;

- custo de aplicação;

- custo relativo ao tempo de aplicação do jogo.

Normalmente, jogos muito complicados e com excesso de detalhes têm uma relação custo-beneficio inadequada. A simplicidade é uma qualidade a ser valorizada tanto pelo criador como pelo usuário do jogo.

Durante o desenvolvimento de um jogo, é fundamental testar o jogo com o objetivo de observar criticamente seu desenrolar e, a partir dos dados obtidos, introduzir mudanças, novas regras, novos papéis ou até mesmo eliminar detalhes e partes do jogo.

O desenvolvimento de um jogo é um trabalho artesanal que exige caracteristicas importantes, tais como: persistência, sensibilidade e criatividade. A equipe de criação deve estar preparada até para mudar completamente a concepção do jogo, em função do que ocorrer nos testes-piloto da versão inicial idealizada.

\subsubsection{Técnica}

A técnica utilizada num jogo de empresas consiste em informar antes aos participantes os objetivos empresariais a que se aspira, as decisões a serem tomadas e as regras a serem aplicadas. Estas instruções podem ser fornecidas oralmente ou por escrito. Cada equipe competidora se organiza, estuda as operações disponíveis e estabelece seu esquema inicial 
de decisões. Cada período-decisão é igual a uma unidade de tempo, podendo ser um dia, uma semana, um mês, um trimestre, um ano, etc. $O$ tamanho das equipes depende das características do jogo. As equipes assumem papéis de uma empresa simulada. Têm-se várias equipes que competirão entre si (Accioly, 1994).

Os demais elementos desse sistema terão seu comportamento simulado com base em um conjunto de relações matemáticas só conhecidas inteiramente pelo coordenador do jogo. As equações que ditam o funcionamento de todos os elementos são informadas aos jogadores.

As decisões tomadas pelas equipes são informadas ao administrador do jogo. Essas decisões afetam, de certa forma, o comportamento dos vários elementos do sistema. $\mathrm{O}$ estado final de um certo número de variáveis é informado a todas as equipes para uma avaliação das decisões tomadas e orientação de novas decisões. Este ciclo de análise de resultados e tomada de decisões é repetido por um certo número de vezes, ao fim dos quais o jogo é encerrado e comentado. Todo jogo, por mais completo que seja, certamente representará apenas uma parte do complexo mundo real.

Os sistemas e subsistemas que estiverem em estudo, objeto do interesse de jogos de treinamento, podem ser descritos com maior ou menor precisão pelas variáveis que o constituem. Geralmente, essas variáveis são escolhidas dentre as que melhor descrevem os sistemas, considerando as relações fundamentais que deverão ser demonstradas durante as atividades práticas.

Tanto a programação de atividades em um evento, quanto o próprio jogo de empresas, adquirem vida graças à interpretação das personagens que cada participante passa a representar desde o início da gestão simulada.

Os papéis geralmente são escolhidos no início do jogo pelos coordenadores do evento ou pelos próprios participantes, seja com o intuito de exercitar as experiências já disponíveis em cada um, seja ainda com o interesse de adquirir novos conhecimentos e habilidades ao desempenhar uma função nova e desconhecida.

Os jogos de empresas devem ser providos de um manual de instruções que contém as regras do jogo:

- uma descrição do meio ambiente simulado e as variáveis externas e internas que o afetam,

- as decisões que devem ser tomadas pelos participantes,

- as restrições e proibições que devem ser obedecidas,

- as conseqüências das decisões,

- orientação aos participantes quanto à organização das equipes e dos trabalhos em si.

\subsubsection{Componentes Básicos para o Projeto de um Jogo}

De acordo com a maioria dos autores, os jogos de empresas, independentemente de sua aplicação, apresentam alguns componentes básicos: papéis, cenário, manual, administrador e/ou coordenador, jogadores e processamento de decisões. 
Todo jogo é desenvolvido sob um sistema de papéis representados pelos seus jogadores, podendo ser classificados em três categorias:

- papéis estruturados, em que os participantes recebem orientações detalhadas com referência ao comportamento que vão adotar. Cada participante tem como responsabilidade montar seu personagem, dentro do perfil recebido;

- papéis semi-estruturados. Neste caso o administrador indica de forma genérica a maneira como cada um deve exercer seu papel;

- papéis desestruturados, em que o administrador apresenta o problema e o próprio grupo determina quem faz o quê e de que forma. Assim, cada um assume o papel que lhe for mais familiar, de forma espontânea, sem interferências ou determinações externas.

O cenário de um jogo é o ambiente em que o jogo irá se realizar. Consiste de dados que tentam definir a realidade dentro da qual o jogo será desenvolvido.

As regras definem claramente o que é e o que não é permitido em um jogo. É muito importante para os participantes entender as regras do jogo. Elas são os limites inerentes ao próprio jogo e que não podem ser ultrapassados, sob o risco de invalidar toda a experiência.

O manual do jogo é um documento onde se encontram todas as regras de funcionamento do jogo, as formas de relacionamento entre os dados de entrada e os de saída, os objetos do jogo, o comportamento esperado dos jogadores, o posicionamento e as definições do jogo, enfim, tudo o que é necessário conhecer de modo a poder explorar toda a potencialidade do jogo e obter sucesso em seu uso. A quebra das regras precisa ser igualmente planejada. Nos casos em que a violação de regras vier a prejudicar os objetivos do jogo, deve haver regras bem explicitas quanto a sanções. Caso o prejuízo seja insignificante, e haja interesse em analisar o comportamento dos transgressores de regras, pode-se dispensar as regras de sanção.

O administrador e/ou coordenador pode ser uma só pessoa ou não, ou seja, as funções exercidas por este papel podem ser divididas entre duas pessoas. É o papel mais importante de um Jogo de Empresa, pois é responsável pela definição dos parâmetros iniciais e de funcionamento do modelo de simulação do ambiente em que o jogo será desenvolvido; comunicação direta com os jogadores e com o módulo de processamento de decisões; coordenação das equipes de jogadores e orientação das suas discussões, análises e avaliações das jogadas possíveis. Em alguns jogos o administrador e/ou coordenador introduz elementos ao longo do jogo, de modo a proporcionar alterações em uma ou várias das características do cenário em que o jogo está se desenvolvendo. Este papel também é responsável pela avaliação tanto dos participantes em treinamento, quanto da eficácia do instrumento utilizado e, principalmente, dos conhecimentos e habilidades desenvolvidas pelos participantes no desenvolvimento do jogo.

Um sistema de processamento de decisões é um sistema utilizado para registrar o andamento dos acontecimentos, representando o termômetro do jogo. Pode tanto ser uma simples tabela que registra as açōes e/ou efeitos, ou um sistema automatizado, que executa os cálculos e armazena todos os dados, sejam eles resultantes do administrador e/ou coordenador - definições do ambiente em que está se desenvolvendo o jogo - ou dos jogadores - definições do valor das variáveis consideradas no ambiente de competição. Este sistema é responsável por receber os dados e processá-los, indicando os resultados 
obtidos para os jogadores; alguns modelos informam, também, ao administrador e/ou coordenador, o andamento do jogo em geral, após cada rodada do jogo.

Os jogadores formam grupos que representam uma empresa. São responsáveis por estudar o ambiente definido pelo jogo e pesquisar as estratégias mais adequadas para vencer o jogo, utilizando para isso de seus conhecimentos teóricos, experiências e habilidades, além dos dados encontrados no manual e dos resultados alcançados em cada rodada do jogo.

\subsubsection{A Dinâmica da Aplicação dos Jogos de Empresas}

Segundo Accioly, a aplicação de um jogo de empresa é normalmente constituída de três fases distintas (Accioly, 1994):

- preparação,

- ciclo repetitivo, e

- encerramento.

Na preparação, os participantes devem receber uma explicação clara e precisa do jogo, de seus objetivos, do tempo de duração do mesmo, dos prazos de entrega das jogadas, da forma como os dados serão recebidos, do comportamento esperado das equipes e de seus componentes e da forma de avaliação final dos resultados atingidos pelas equipes, além de outros esclarecimentos adicionais decorrentes das necessidades específicas de cada grupo em treinamento. A maioria destas informações deverá estar no Manual do Jogo.

Ao mesmo tempo, o Coordenador deverá fixar os parâmetros iniciais do jogo, que incluem as variáveis que deverão ser analisadas pelas equipes ao longo das jogadas, preparar o local fisico onde ocorrerão as discussões em geral e, principalmente, a segunda fase - ciclo repetitivo.

Logo após, é necessário definir o tamanho e a composição das equipes, o que pode ser feito pelo Coordenador ou pelas próprias equipes. Cada equipe deverá definir o papel de cada um de seus componentes, inclusive o seu líder, o qual será o responsável, perante o Coordenador, pela entrada de dados de cada jogada e obtenção dos resultados atingidos pela equipe.

A partir de então, dá-se início à segunda fase do jogo - ciclo repetitivo. Em cada um dos ciclos repetitivos desta fase as equipes, após os estudos necessários, deverão apresentar suas decisões por meio das varáveis estabelecidas pelo Coordenador na fase anterior. Com a definição dessas variáveis é processada a simulação e os resultados são gerados. Novos estudos são realizados em torno destes resultados e como conseqüência novas decisões são tomadas em um novo ciclo. As equipes que demonstrarem maiores dificuldades ou piores desempenhos relativos deverão ser estudadas pelo Coordenador a fim de analisar as causas destes desempenhos e propor medidas de melhoria.

Em alguns Jogos de Empresa o Coordenador pode incluir, ao longo do jogo, parâmetros destinados a alterar algumas das características do ambiente. Quando isso ocorre, há necessidade de existir um meio formal de levar estas situações ao conhecimento dos jogadores. 
Ao longo de todo o jogo o Coordenador deve fazer uma avaliação de todos os participantes quanto à participação, conhecimentos demonstrados e precisão de suas análises.

Finalmente, na fase de encerramento, o Coordenador, em conjunto com todas as equipes envolvidas, avalia os resultades obtidos por cada equipe e comenta as estratégias seguidas, enfatizando os erros e acertos spresentados.

\subsection{Jogos na Área de Gestão de Projetos de Software}

A gestão de projetos é a primeira camada do processo de Engenharia de Software. É chamada de camada em vez de etapa ou atividade, porque ela abrange todo o processo de desenvolvimento de software, do começo ao fim.

Para que um projeto de software seja bem conduzido, o escopo do trabalho a ser feito, os riscos, os recursos exigidos, as tarefas a serem executadas, os marcos de referência a serem acompanhados, os custos e a programação a ser seguida devem ser bem compreendidos. Esta compreensão é oferecida pela gestão de projetos de software e começa antes do trabalho técnico, prossegue à medida que o software se desenvolve e encerra somente quando o software se torna obsoleto.

Uma vez que a gestão dos projetos de software é tão importante para o sucesso de um projeto, os gerentes de projetos deveriam entender como colocá-la em prática e como trabalhar dentro dos limites estabelecidos por ela. Entretanto, não é o que ocorre na prática. A "crise do software" demonstrou a ineficiência existente em gerenciar o planejamento, custo e qualidade dos projetos de desenvolvimento de software. Essa crise continua ainda hoje infestando a maioria dos projetos (Boehm, 1981; Jones, 1991). Porém, muitos destes projetos poderiam não fracassar se certos erros comuns de gerenciamento de projeto pudessem ser evitados.

Segundo Boehm (1981), "deficiências no gerenciamento podem aumentar o custo do software mais rapidamente do que qualquer outro fator". Além disso, de acordo com Jones (1991) e Statz (1994), a principal causa da deficiência no gerenciamento de projeto é a inadequação dos treinamentos e critérios de gerenciamento utilizados. Portanto, é necessário definir uma técnica para julgar o desempenho do gerenciamento de projeto, pois é dificil melhorar uma atividade sem um método de avaliação de desempenho desta atividade.

O gerenciamento de projeto de software envolve, dentre outras tarefas: planejamento, direcionamento e controle de um projeto de desenvolvimento de software. Estas habilidades requerem: conhecimento, ter conhecimento dos erros comuns de gerenciamento de projeto; e técnicas, como a habilidade de reconhecer essas armadilhas e formular um novo plano de projeto. Existem vários métodos de melhoria das técnicas de gerenciamento de projeto de software e dentre eles estão os jogos, que por intermédio da realização de simulações em computador é capaz de apoiar o treinamento dos gerentes de projeto de software.

Merril e Collofello (1997) desenvolveram uma ferramenta, chamada por eles de simulador, para treinar estudantes em atividades de gestão de projetos de software. Segundo esses autores as técnicas de gestão de projeto de software estão se tornando um componente importante para os softwares educativos. Engenheiros de software que trabalham em equipes precisam planejar e coordenar cuidadosamente seus esforços para 
serem bem sucedidos. Ainda segundo eles, a maioria das universidades fornece aos estudantes uma educação inadequada e deficiente quanto a experiências em gestão de projeto de software.

A ferramenta desenvolvida por Merrill e Collofello fornece uma ponte entre os conceitos teóricos e práticos, e também uma medida útil de avaliação de desempenho de estudantes nos processos educativos. Também é capaz de simular as atividades de desenvolvimento de software por intermédio da representação dinâmica de atributos relevantes do projeto no processo de desenvolvimento de software.

O Quadro 3.2 apresenta o processo de criação do ambiente de simulação seguido para garantir que os objetivos de treinamento sejam satisfatórios. Os passos são repetidos várias vezes para que seja possível capturar todos os objetivos do treinamento.

Quadro 3.2- Um processo iterativo de desenvolvimento de uma ferramenta de simulação de treinamento baseada na dinâmica de sistemas (Merril \& Collofello, 1997)

\begin{tabular}{|c|c|c|}
\hline & Objetivos & $x_{i}$ \\
\hline 1. & $\begin{array}{l}\text { Planejamento das } \\
\text { Lições }\end{array}$ & $\begin{array}{l}\text { - decompor os objetivos de treinamento em subtópicos } \\
\text { - } \quad \begin{array}{l}\text { criar uma lição planejada para cada subtópico } \\
\text { determinar se a simulação é uma abordagem adequada para cada liçăo } \\
\text { planejada }\end{array}\end{array}$ \\
\hline 2. & $\begin{array}{l}\text { Interface da } \\
\text { Ferramenta } \\
\text { (Simulador) }\end{array}$ & $\begin{array}{l}\text { - determinar o processo relevante, o produto e os atributos pessoais que serão } \\
\text { mostrados ao usuário } \\
\text { determinar que atributos sáo controlados pelo usuário }\end{array}$ \\
\hline 3. & Simulador & $\begin{array}{l}\text { - } \quad \text { determinar os limites do modelo } \\
\text { - } \quad \text { selecionar ou criar um modelo apropriado } \\
\text { - } \quad \text { adicionar algumas lições específicas aos componentes do modelo } \\
\text { - } \quad \text { automatizar todas as partes do modelo que năo sâo relevantes para as liçöes }\end{array}$ \\
\hline 4. & $\begin{array}{l}\text { Cenários da } \\
\text { Ferramenta }\end{array}$ & $\begin{array}{l}\text { - especificar valores para os cenários } \\
\text { - determinar limites para julgamento do desempenho dos estudantes }\end{array}$ \\
\hline 5. & Vaiidação & $\begin{array}{l}\text { - veriflcar o comportamento do modelo } \\
\text { - verificar quais cenários são reaiísticos } \\
\text { verificar se os desempenhos dos estudantes estão sendo s } \\
\text { respeitando os objetivos de treinamento apresentados no passo } 1 .\end{array}$ \\
\hline
\end{tabular}

A eficácia desta abordagem é dividida entre os beneficios apresentados no Quadro 3.3. Suas limitações são listadas a seguir:

- esta abordagem é somente aplicável a treinamentos objetivos que enfocam o planejamento, as diretrizes e o controle de desenvolvimento. Outras técnicas de gestão de software (por exemplo, técnicas de comunicação) são melhor aprendidas utilizando outros métodos,

- esta abordagem requer clareza na definição dos objetivos de treinamento. Se os objetivos não estão claros, o treinamento será pouco efetivo.

Quadro 3.3- Os beneficios potenciais de uma ferramenta baseada na dinâmica de sistemas (Merril \& Collofello, 1997)

\begin{tabular}{|l|l|}
\hline Atributos & Beneficios
\end{tabular}


A eficiência desta abordagem é limitada pelo esforço de tempo despendido em criar a ferramenta de treinamento, porém, a ferramenta pode ser facilmente reutilizada em diferentes cenários e por outros grupos de participantes.

Para avaliar a utilidade da ferramenta de treinamento de gestão de projeto de software foi realizada uma experiência em que os participantes eram todos estudantes. $O$ objetivo dessa experiência era avaliar se o uso da ferramenta ajudaria os estudantes a aprender as lições de gestão de projeto de software. Inicialmente, os estudantes foram inspecionados sobre seus conhecimentos da dinâmica de gestão de projetos. Após a pesquisa, equipes de estudantes foram formadas. Para cada equipe foi determinado um papel de gestão de projeto.

Os detalhes do projeto, do processo de desenvolvimento, do produto, das pessoas, as métricas históricas de projetos passados $\mathrm{e}$, inclusive, um plano de projeto baseado em dados de estimação de custo COCOMO, foram fornecidos aos participantes. A primeira simulação foi executada sem o controle dos participantes e terminou na hora certa, dentro do orçamento, e com os padrões de qualidade exigidos. Isto permitiu aos participantes se familiarizarem com a ferramenta de simulação e o projeto simulado. Em uma segunda simulação foi apresentado o problema de re-planejamento às equipes com $10 \%$ de aumento nas exigências do produto. A interface da ferramenta desenvolvida por Merril e Collofello (1997) é apresentada na Figura 3.1.

Os controles permitidos às equipes foram:

- aumento obrigatório das horas extras do trabalhador;

- contratação de engenheiros mais experientes;

- modificação da quantidade de engenheiros alocados em atividades de garantia de qualidade;

- extensão da data planejada de conclusão; e

- corte da funcionalidade do produto em $10 \%$.

As equipes escolheram suas estratégias baseadas nas seguintes diretrizes:

- o projeto seria considerado um fracasso se não apresentasse um tempo de ciclo menor, menos defeitos e custo mais baixo que um mesmo projeto desenvolvido sem mudanças em seu plano, e

- o sucesso dos projetos seriam julgados por seus tempos de ciclo, qualidade (número de defeitos e a funcionalidade do produto) e custo (número de dias de engenheiros inexperientes e experientes multiplicado por seus custos).

Como resultado da simulação, os estudantes participantes ganharam alguma perspicácia na dinâmica de um grande projeto de desenvolvimento, o que foi comprovado pela diferença entre suas pesquisas iniciais e finais.

Yourdon (1996) também descreve uma experiência com um jogo sobre gerenciamento de projetos de software em que equipes de profissionais de software e/ou supervisores de projeto podem competir uns com os outros, numa imitação de batalha, para decidir quem pode "vencer", terminando o projeto na data prevista, dentro do orçamento, com o menor número de defeitos, etc. Para tornar as experiências mais interessantes, os modelos continham também alguns eventos "aleatórios", como por exemplo: mudanças imprevistas nos requisitos dos usuários, cortes orçamentários, crises políticas e talvez até a saída imprevista de algum membro-chave da equipe no meio do projeto. Um relatório resumindo 
o jogo permitia que as equipes articulassem as premissas e os modelos mentais que utilizaram durante o jogo.

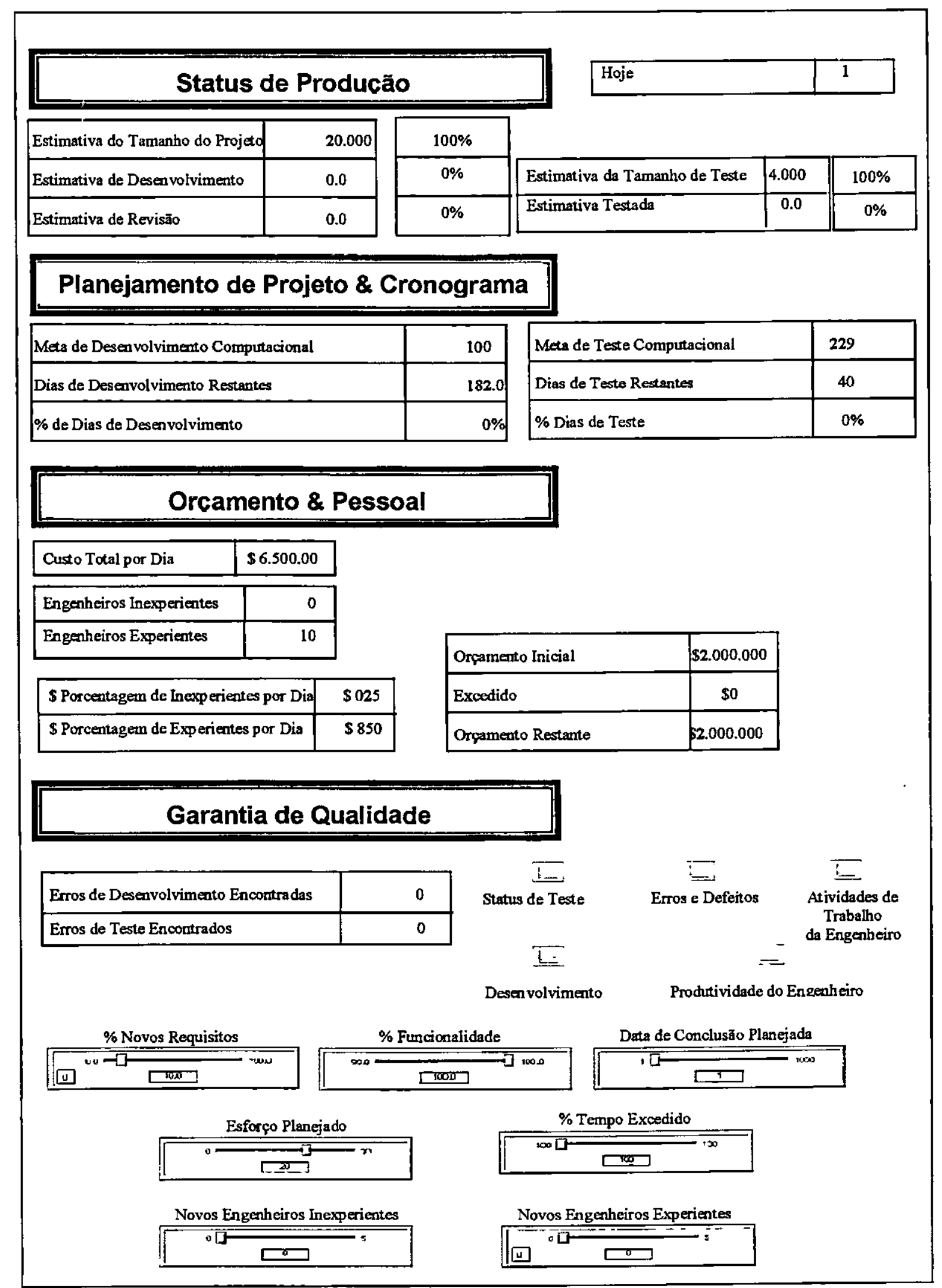

Figura 3.1 - Interface do Usuário da Ferramenta de Treinamento de Gerenclamento de Projeto de Software (Merril \& Collofello, 1997) 
As Tabelas $3.1,3.2,3.3$ e 3.4 ilustram os resultados de um jogo que envolveu 125 pessoas em 19 equipes competidoras. Nesse jogo, as atividades de desenvolvimento de software de uma empresa de Tecnologia de Informação inteira foram modeladas e as equipes competidoras tinham de decidir quanto dinheiro deveria ser alocado para aumentos anuais de salários, quanto deveria ser investido em ferramentas CASE, quanto deveria ser gasto em treinamento, etc. Nove "rodadas" de simulação foram realizadas. Em cada rodada foram tomadas decisões, que foram então introduzidas no modelo de simulação, e os resultados foram impressos.

Tabela 3.1- Resultados Cumulativos de Jogos CASE (Yourdon, 1996)

\begin{tabular}{|c|c|c|c|c|c|c|c|c|c|c|c|}
\hline & 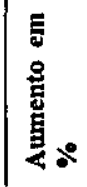 & 总总密 & 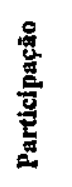 & 苞 & 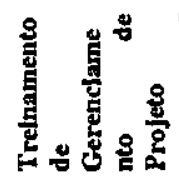 & 里号 & 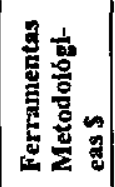 & 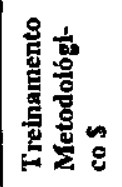 & ه & 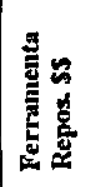 & 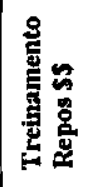 \\
\hline \begin{tabular}{|l|}
$\mathrm{T} 01$ \\
\end{tabular} & $5,0 \%$ & $\$ 810$ & 1,00 & 400 & 1500 & 0,75 & 3000 & 1500 & 200 & 800 & 300 \\
\hline T02 & $2,0 \%$ & $\overline{\$} 1.050$ & 0,85 & 40 & 100 & 0,80 & 1200 & 800 & 500 & 350 & 100 \\
\hline T03 & $4,0 \%$ & $\$ 700$ & 0,75 & 200 & 300 & 0,95 & 1000 & 1500 & 200 & 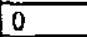 & 0 \\
\hline \begin{tabular}{|l|} 
T04 \\
\end{tabular} & $1,0 \%$ & $\$ 1.055$ & 1,00 & 40 & 300 & \begin{tabular}{|l|}
0,90 \\
\end{tabular} & 1000 & \begin{tabular}{|l|l|}
1000 \\
\end{tabular} & 100 & 0 & 10 \\
\hline T05 & $2,0 \%$ & $\$ 950$ & 0,95 & 200 & 200 & 0,30 & 1000 & 800 & 50 & 400 & 200 \\
\hline \begin{tabular}{|l|} 
T06 \\
\end{tabular} & $3,0 \%$ & 5900 & 0,90 & 200 & 150 & \begin{tabular}{|l}
0,80 \\
\end{tabular} & 1500 & \begin{tabular}{|l|l|}
1000 \\
\end{tabular} & 0 & 300 & 350 \\
\hline $\mathrm{T} 07$ & $5,0 \%$ & S1.001 & 0,80 & 15 & 100 & $0,0,70$ & 550 & 600 & 10 & 150 & 75 \\
\hline T08 & $1,0 \%$ & $\$ 1.000$ & 0,95 & 50 & 750 & 0,50 & 4000 & 3000 & 1500 & 0 & 150 \\
\hline \begin{tabular}{|l|l} 
T09 \\
\end{tabular} & $3,0 \%$ & $\$ 950$ & 0,65 & 40 & 60 & 0,95 & 3000 & 1760 & 500 & 60 & 100 \\
\hline \begin{tabular}{|l|} 
T10 \\
\end{tabular} & $2,0 \%$ & $\$ 900$ & 1,00 & 200 & 2000 & \begin{tabular}{|l|}
1,00 \\
\end{tabular} & \begin{tabular}{|l}
1500 \\
\end{tabular} & 2000 & 500 & 800 & 500 \\
\hline T12 & $2,0 \%$ & $\$ 1.000$ & 0,70 & 300 & 500 & 0,80 & 1000 & 2000 & 1000 & 100 & 50 \\
\hline \begin{tabular}{|l|} 
T13 \\
\end{tabular} & $2,0 \%$ & $\$ 1.000$ & 0,90 & 75 & 100 & 0,70 & 1500 & 1500 & 100 & 50 & 100 \\
\hline \begin{tabular}{|l|}
$\mathrm{T} 14$ \\
\end{tabular} & $2,0 \%$ & $\$ 1.200$ & 1,00 & 100 & 200 & 0,80 & 1500 & 2000 & 100 & 250 & 500 \\
\hline T15 & $3,0 \%$ & $\$ 1.100$ & 1,00 & 100 & 300 & 0,70 & 700 & 2300 & 200 & 4400 & 1600 \\
\hline T16 & $2,0 \%$ & $\$ 950$ & 1,00 & 200 & 500 & 1,00 & 2000 & 3000 & 250 & 200 & 300 \\
\hline \begin{tabular}{|l|} 
T17 \\
\end{tabular} & $2,5 \%$ & $\$ 1.00$ & 0,90 & 100 & 300 & 0,73 & 1000 & 2000 & 100 & 100 & \begin{tabular}{|l|l|}
100 \\
\end{tabular} \\
\hline \begin{tabular}{|l|} 
T18 \\
\end{tabular} & $2,0 \%$ & 5950 & 1,00 & 40 & 25 & 0,85 & \begin{tabular}{|l}
1600 \\
\end{tabular} & 960 & 40 & 50 & 30 \\
\hline T19 & $1,0 \%$ & $\$ 1.000$ & 0,75 & 100 & 50 & 0,30 & \begin{tabular}{|l}
1000 \\
\end{tabular} & 100 & 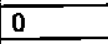 & 100 & 10 \\
\hline$T 20$ & $2,0 \%$ & $\$ 950$ & 0,55 & 60 & 1000 & 0,80 & 3000 & 1500 & 50 & 750 & 200 \\
\hline \begin{tabular}{|l|l} 
Média \\
\end{tabular} & $2,4 \%$ & 5969 & 0,88 & 128 & \begin{tabular}{|l|}
444 \\
\end{tabular} & 0,75 & 1634 & 1543 & 284 & 256 & 243 \\
\hline
\end{tabular}

Tabela 3.2- Resultados de um Jogo Baseado em Dinâmica de Sistemas (Yourdon, 1996)

\begin{tabular}{|c|c|c|c|c|c|c|c|c|c|c|c|c|}
\hline & 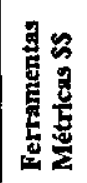 & 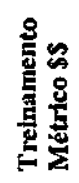 & 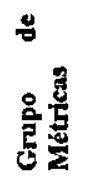 & 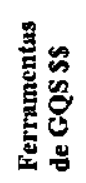 & 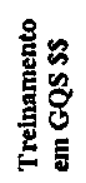 & 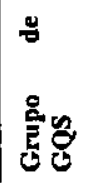 & 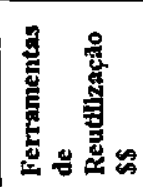 & 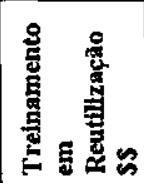 & 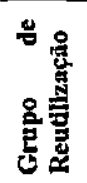 & 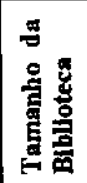 & 宽 & 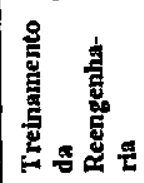 \\
\hline T01 & 700,0 & 200 & 3,0 & 1600 & 500 & 5,0 & 500 & 300 & 3 & 400 & 600 & 400 \\
\hline T02 & 50,0 & 50 & 2,0 & 50 & 500 & 2,5 & \begin{tabular}{|l|}
50 \\
\end{tabular} & 100 & 2,5 & 500 & 100 & 100 \\
\hline T03 & \begin{tabular}{|l}
00,0 \\
\end{tabular} & 30 & 3,0 & 10 & 140 & \begin{tabular}{|l|}
3,0 \\
\end{tabular} & \begin{tabular}{|l|}
50 \\
\end{tabular} & \begin{tabular}{|l|}
250 \\
\end{tabular} & 2 & 500 & 100 & 150 \\
\hline T04 & 70,0 & 200 & 3,0 & 75 & 350 & 4,0 & \begin{tabular}{|l|}
50 \\
\end{tabular} & 100 & 3 & 500 & 0 & 0 \\
\hline T05 & 10,0 & 5 & 2,0 & 100 & 600 & 3,0 & 200 & 300 & 10 & 1000 & 80 & 40 \\
\hline T06 & \begin{tabular}{|l|l}
100,0 \\
\end{tabular} & 55 & 3,0 & 50 & 500 & 3,0 & \begin{tabular}{|l|}
150 \\
\end{tabular} & 250 & 10 & \begin{tabular}{|l|}
750 \\
\end{tabular} & 300 & 50 \\
\hline T07 & 1,0 & $\overline{0,5}$ & 2,5 & 3 & 1,5 & 3,0 & 10 & 15 & 5 & 800 & 100 & 50 \\
\hline T08 & 75,0 & 25 & 4,0 & 100 & 250 & 5,0 & \begin{tabular}{|l|}
10 \\
\end{tabular} & 10 & 2 & 300 & 0 & 10 \\
\hline T09 & 30,0 & 30 & 3,0 & 40 & 30 & 3,0 & 30 & 20 & 1 & \begin{tabular}{|l|}
200 \\
\end{tabular} & 300 & 100 \\
\hline T10 & 300,0 & 300 & 3,0 & 500 & 1000 & 5,0 & 200 & \begin{tabular}{|l|l}
1500 \\
\end{tabular} & 3 & 500 & 500 & 500 \\
\hline T12 & 75,0 & 125 & 3,0 & 250 & 500 & 3,0 & 150 & 200 & 4 & 750 & 25 & 250 \\
\hline T13 & 75,0 & 100 & 3,0 & 75 & 100 & 3,0 & 100 & 200 & 5 & 500 & 50 & \begin{tabular}{|l|l|}
100 \\
\end{tabular} \\
\hline T14 & 150,0 & 100 & 3,0 & 5 & 200 & 2,0 & 10 & 100 & 2 & 400 & 200 & 20 \\
\hline T15 & 600,0 & 1800 & 5,0 & 10 & 1000 & 1,0 & 0 & 100 & 2 & 500 & $\overline{10}$ & 20 \\
\hline T16 & \begin{tabular}{|l|}
100,0 \\
\end{tabular} & 200 & 3.0 & 200 & 400 & 3,0 & 200 & \begin{tabular}{|l|}
400 \\
\end{tabular} & 4 & 100 & 100 & 200 \\
\hline T17 & \begin{tabular}{|l|}
75,0 \\
\end{tabular} & 100 & 2,0 & 250 & 500 & 3,0 & 200 & 400 & 4 & 500 & 100 & 200 \\
\hline T18 & 10,0 & 6 & 2,0 & 10 & 6 & 3,0 & 30 & 20 & 4 & 1000 & 30 & 20 \\
\hline T19 & 100,0 & 10 & 2,0 & 500 & 1000 & \begin{tabular}{|l|}
3,0 \\
\end{tabular} & 500 & \begin{tabular}{|l|l}
100 \\
\end{tabular} & 5 & \begin{tabular}{|l|}
500 \\
\end{tabular} & 0 & 0 \\
\hline $\mathrm{T} 20$ & 0,5 & 100 & 2,0 & 300 & 1000 & 10,0 & \begin{tabular}{|l|}
100 \\
\end{tabular} & 500 & 30 & \begin{tabular}{|l|l|}
750 \\
\end{tabular} & 1000 & 1000 \\
\hline Média & \begin{tabular}{|l|l} 
\\
\end{tabular} & 181 & 2,8 & 217 & 404 & 3,6 & 134 & 256 & 5 & 550 & 189 & 157 \\
\hline
\end{tabular}


Yourdon, na qualidade de mediador do jogo, impôs duas regras. Primeiro, cada equipe tinha permissão para ver os resultados das demais equipes durante todas as rodadas intermediárias da competição. Segundo, qualquer equipe tinha permissão para modificar suas decisões anteriores caso tivesse chegado à conclusão de que havia cometido um erro terrível. Sob essas duas condições, esperava-se que todas as equipes fossem gradualmente convergindo para um conjunto comum de decisões, pois poderiam recuperar-se de seus erros e observar sucessos de outras equipes. No entanto, foi uma grande surpresa ver os resultados finais, apresentados nas Tabelas $3.1,3.2,3.3$ e 3.4 . Na maioria dos itens, houve uma variância de 10 para 1 entre as equipes. A quarta coluna de dados na Tabela 3.1, por exemplo, ferramenta de gerenciamento de projeto, representa a quantia de dinheiro (em milhares de dólares) que a equipe sentiu que deveria gastar com ferramentas de gerenciamento de projeto.

Tabela 3.3- Resultados de um Jogo Baseado em Dinâmica de Sistemas (continuação) (Yourdon, 1996)

\begin{tabular}{|c|c|c|c|c|c|c|c|c|c|}
\hline & 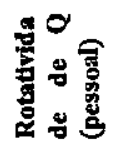 & 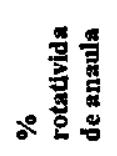 & 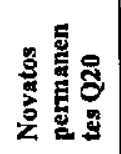 & 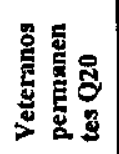 & 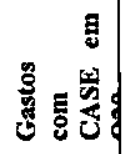 & 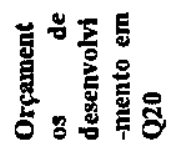 & 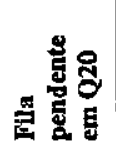 & 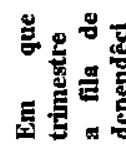 & 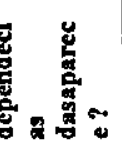 \\
\hline T01 & 2 & $5,50 \%$ & 4 & 148 & 9050 & 7376 & 18 & 12 & \\
\hline $\mathrm{T02}$ & 2 & $7,30 \%$ & 3 & 149 & 16430 & 13194 & 18 & 12 & \\
\hline T03 & 2 & $8,10 \%$ & 21 & 147 & 16170 & 10043 & 41 & 30 & \\
\hline T04 & 2 & $5,90 \%$ & 2 & 148 & 16815 & 15399 & 18 & 11 & \\
\hline T0S & 2 & $6,30 \%$ & 8 & 148 & 15865 & 13440 & 18 & 15 & \\
\hline T06 & 2 & $6,70 \%$ & 12 & 148 & 15045 & 11562 & 18 & 16 & \\
\hline TOn & 2 & $7,50 \%$ & 0 & 146 & 18329 & 4369 & 18 & 11 & \\
\hline T08 & 2 & $5,90 \%$ & 4 & 148 & 11620 & 15355 & 18 & 12 & \\
\hline T09 & 3 & $9,20 \%$ & 27 & 137 & 14400 & 12618 & 18 & 19 & \\
\hline T10 & 2 & $5,80 \%$ & 0 & 148 & 8200 & 13766 & 18 & 10 & \\
\hline T12 & 3 & $8,80 \%$ & 21 & 137 & 14700 & 14332 & 18 & 17 & \\
\hline T13 & 2 & $6,80 \%$ & 10 & 148 & 15875 & 13711 & 18 & 16 & \\
\hline T14 & 2 & $5,70 \%$ & 2 & $\overline{148}$ & 14665 & 13375 & 18 & 11 & \\
\hline T15 & 2 & $5,70 \%$ & 0 & 148 & 9160 & 11632 & 18 & 10 & \\
\hline T16 & 1 & $5,30 \%$ & 0 & 147 & 12000 & 10404 & 18 & 8 & \\
\hline T17 & 2 & $6,65 \%$ & 2 & 148 & 14575 & 10670 & 18 & 11 & \\
\hline T18 & 2 & $5,70 \%$ & 0 & 152 & 17163 & 12328 & 18 & 12 & \\
\hline T19 & 2 & $7,90 \%$ & 12 & 148 & 16430 & 15224 & 18 & 16 & \\
\hline $\mathrm{T} 20$ & 2 & $8,30 \%$ & 24 & 144 & 9490 & 13618 & 18 & $\begin{array}{l}\text { quando o } \\
\text { congelar }\end{array}$ & inferno \\
\hline Media & 2 & $6,79 \%$ & 8 & 147 & 13999 & 12232 & 88 & 14 & \\
\hline
\end{tabular}

Tabela 3.4- Resultados de um Jogo de Guerra em Dinâmica de Sistemas (continuação) (Yourdon, 1996)

\begin{tabular}{|c|c|}
\hline T01 & $\begin{array}{l}\text { Aumentos de produtividade: } 15 \% \text { em geragào do projeto, } 17 \% \text { em metodologia, } 1 \% \text { em repositório, } 10 \% \text { em } \\
\text { metrica, } 15 \% \text { em GQS, } 2 \% \text { em reutilizaçao e reengenharia. }\end{array}$ \\
\hline T02 & Contratação permitida de veteranos $=20 \%$ de novatos contratados. \\
\hline T03 & $\begin{array}{l}\text { Aumentos de produtividade: } 15 \% \text { em geracão do projeto } 17 \% \text { em metodologia, } 1 \% \text { em repositónio, } 10 \% \text { em métrica, } \\
15 \% \text { em GQs, } 2 \% \text { em reutilizaçăo e reengenharia. }\end{array}$ \\
\hline T04 & Nenhuma mudanca solicitada. \\
\hline T05 & Nenhuma mudanca solicitada. \\
\hline T06 & Componentes reutilizáveis passaram a ser criados em um mês em vez de em très meses. \\
\hline To7 & Novatos transformados em veteranos em um trimestre; consequentemente os novatos desaparecem em Q12. \\
\hline T08 & Nenhuma mudanca solicitada. \\
\hline T09 & Nenhuma mudanca solicitada. \\
\hline T10 & $\begin{array}{l}\text { Componentes reutilizáveis criados em um mês em vez de em três meses - NENHUM EFEITO NOTADO. } \\
\text { possivelmente ferramenta inadequada } \$ \$ \text {. }\end{array}$ \\
\hline T12 & Customização de metodologia \$\$ duplicou impacto de produtividade da metodologia - NENHUM EFEITO NOTADO. \\
\hline T13 & Nenhuma mudança solicitada. \\
\hline T14 & Componentes reutilizáveis criados em um mês em vez de três meses - NENHUM EFEITO NOTADO. \\
\hline T15 & Máximo aumento de prochutividade sem treinamento foi diminuido para 30\% - NENHUM EFEITONOTADO. \\
\hline T16 & Novatos eliminados, empresa contrata somente veteranos. \\
\hline T17 & A T17 solicitou um fator de "taxa de aprendizado" - demasiadamente dificil de ser implementado a essa altura. \\
\hline T18 & Novatos transformam-se em veteranos em seis trimestres, em vez de 10 \\
\hline T19 & Treinamento agora tem duas vezes mais impacto sobre aumento de produtividade do que cada tipo de ferramenta. \\
\hline T20 & NENHUMA MUDANCAA FOI SOLICITADA EM RELAÇĀO AO MODELO. \\
\hline
\end{tabular}


Segundo Yourdon (1996), o mais surpreendente foi a atitude de várias equipes no momento de alterar suas decisões; de fato, com raras excę̧ões, nenhuma das decisões foi modificada após ter sido tomada, independentemente dos resultados observados de outras equipes. $\mathrm{O}$ único item que foi objeto de constantes mudanças - na verdade, diferentes valores foram introduzidos em cada uma das nove rodadas - foi a decisão sobre aumentar os salariais anuais.

Muitos outros trabalhos envolvendo simulações do desenvolvimento de software baseados na Dinâmica de Sistemas podem ser encontrados na literatura. Entretanto, o trabalho de Abdel-Hamid e Madnick (1991) em simulação do desenvolvimento de software é o mais completo até os dias de hoje.

\subsection{Consideraçōes Finais}

Neste capitulo foram abordados os principais conceitos que envolvem os Jogos de Empresas. Foram também apresentados a importância do desenvolvimento de uma ferramenta de apoio à gestão de projetos de software que possa proporcionar um tipo de aprendizagem organizacional aos gerentes de projetos de software; e alguns jogos na área de gestão de projetos de software.

A partir do estudo realizado são apresentados, em maiores detalhes, no próximo capítulo, a adaptação da ferramenta Cycles para uma ferramenta que apoia jogos e o desenvolvimento de um jogo para gestão de projetos de software baseado na dinâmica de sistemas. 


\subsection{Considerações Iniciais}

De acordo com a pesquisa realizada nos capítulos anteriores e a proposta deste trabalho, neste capítulo é apresentada a ferramenta desenvolvida para a criação e aplicação de Jogos de Empresas baseados na modelagem da Dinâmica de Sistemas. O processo de desenvolvimento da ferramenta é detalhado neste capítulo e esta organizado em três seções.

A seção 4.2 apresenta as adaptações por que passou a ferramenta Cycles e que foram necessárias para torná-la adequada a uma futura extensão para a criação da ferramenta proposta neste trabalho. A seção 4.3 apresenta a nova arquitetura desenvolvida para a ferramenta proposta. Finalmente, na seção 4.4 são apresentadas as extensões realizadas durante o desenvolvimento da ferramenta proposta: modelagem conceitual, aspectos do projeto da base de dados e aspectos da implementação da ferramenta.

\subsection{O Processo de Adaptação da Ferramenta Cycles}

Por este trabalho ter sido baseado em outro desenvolvido anteriormente por Garcia (1998), uma ferramenta - Cycles - para apoiar a modelagem e a simulação da Dinâmica de Sistemas, foi necessário um estudo mais detalhado dessa ferramenta; o entendimento de sua funcionalidade e de sua implementação.

Considerando a funcionalidade, essa ferramenta apresenta uma interface gráfica que permite a edição de modelos dinâmicos. A edição gráfica é dividida em dois niveis. $\mathrm{O}$ primeiro nível é destinado à edição dos subsistemas que integram o modelo. $O$ segundo nível é utilizado para uma edição mais detalhada de cada subsistema editado no nível anterior. Nesse nível cada subsistema é apresentado segundo um modelo estabelecido e baseado na Dinâmica de Sistemas proposta por Forrester (1961). Assim, juntamente com o modelo gráfico, o comportamento do subsistema é representado por expressões matemáticas e valores iniciais de seus componentes e variáveis.

Durante a edição de um modelo, a ferramenta permite que operações incorretas e inconsistências sejam feitas. Desta forma, é necessário realizar uma validação do modelo feita antes de uma simulação, para que expressões, ligações e estruturas estabelecidas no modelo sejam validadas e verificadas.

Caso o modelo não apresente erros a simulação de seu comportamento é realizada e os resultados obtidos para o periodo de tempo estabelecido inicialmente são apresentados em uma tabela. Nessa tabela de resultados as linhas apresentam os resultados de cada ciclo do período de tempo estabelecido e as colunas apresentam os valores dos componentes do modelo. Os resultados obtidos podem ser visualizados em forma de gráfico, que facilitam a análise dos dados.

Para um melhor entendimento da funcionalidade da ferramenta Cycles alguns modelos foram editados e simulados. Durante algumas dessas simulações observou-se a ocorrência de alguns erros que somente após um estudo detalhado do código da ferramenta puderam ser entendidos e corrigidos. Esses erros ocorriam por duas razões: falta de ordenação dos componentes do modelo do sistema e atribuição de valores iniciais nulos a todas as variáveis do modelo. 
Conforme apresentado anteriormente, um modelo dinâmico é representado por constantes, níveis, variáveis, e taxas que se relacionam entre si. As constantes são valores numéricos, que como o próprio nome diz, não são alterados durante a simulação. Os níveis, as variáveis e as taxas são representados por expressões matemáticas formadas por outros componentes: constantes, níveis, variáveis ou taxas. Desta forma, para que uma expressão matemática seja calculada corretamente ela deve possuir os valores corretos de todos os seus componentes (operandos) que já devem ter sido calculados anteriormente. Por exemplo, considerando a expressão:

$$
\begin{aligned}
& -\quad \boldsymbol{X}=\boldsymbol{A}+\boldsymbol{B} \text { em que, } \\
& A=C-D \\
& B=C+D \\
& C=5 \\
& D=8
\end{aligned}
$$

Para calcular o valor de $\mathbf{X}$ é necessário que $\mathbf{A}$ e $\mathbf{B}$ já tenham sido calculados e assim sucessivamente para se calcular os valores de $\mathbf{A}$ e $\mathbf{B}$.

Desta maneira, se torna necessário, antes da realização de qualquer cálculo, uma ordenação dos componentes do sistema. Entretanto, pela faita da implementação na ferramenta Cycles desta ordenação, erros foram observados durante o cálculo de alguns componentes de certos modelos.

A simulação do comportamento de um modelo dinâmico é realizada a partir das atribuições de valores iniciais aos componentes do modelo. As constantes e os níveis, utilizados no início da simulação, devem receber valores iniciais durante a fase de modelagem. Já as variáveis e as taxas, que são componentes do modelos representados por expressões, devem apresentar um valor calculado inicialmente quando possível. Ou seja, apenas aquelas variáveis e taxas que são formadas somente por constantes ou niveis, poderão ser calculadas. As outras, aquelas que são formadas por outras variáveis ou taxas que impossibilitam um cálculo inicial, deverão receber valores nulos.

$\mathrm{Na}$ implementação da ferramenta Cycles pôde ser observado, após uma análise dos cálculos obtidos na simulação de alguns modelos, que as todas as variáveis do modelo, incluindo aquelas que poderiam ser calculadas, por apresentarem apenas constantes e níveis em sua fórmula, recebiam inicialmente valores nulos, o que em muitos modelos resultava em dados incorretos na simulação.

Estas falhas foram resolvidas pela implementação do algoritmo de ordenação topológica (Wirth,1976). Esse algoritmo é desenvolvido sob um grafo dirigido que pode ser originado de um modelo dinâmico e formar uma rede de variáveis. Esse grafo dirigido é formado por vértices e arcos. Os vértices representam as variáveis do modelo e os arcos as relações de precedência entre o cálculo das variáveis. Assim, esse algoritmo, destinado a classificar as variáveis do modelo por ordem cronológica, consiste em três etapas: selecionar uma variável do modelo que não possui predecessor, armazená-la em uma lista ordenada e retirá-la, juntamente com todas as suas saídas de influência para outras variáveis, do grafo. Essas etapas são repetidas até que todas as variáveis do modelo tenham sido analisadas.

Outra alteração realizada na implementação da ferramenta Cycles foi a inclusão da opção de executar uma simulação com ou sem pausas a cada periodo de tempo. $\mathrm{Na}$ implementação original a simulação era executada completamente, ou seja, todos os períodos eram calculados em uma só vez. Não havia a possibilidade de alterar uma variável durante a simulação. 
Assim, antes de se iniciar as adaptações necessárias à extensão da ferramenta Cycles para apoiar Jogos de Empresas, foram implementadas as devidas alterações para correção das falhas mencionadas anteriormente. Entretanto, o princípio adotado nessas alterações foi o de tentar aproveitar ao máximo o código já existente realizando apenas as adaptações estritamente necessárias.

\subsection{Arquitetura da Ferramenta de Apoio a Jogos de Empresas}

Como o objetivo principal deste trabalho era o desenvolvimento de uma ferramenta genérica de apoio a Jogos de Empresas que fosse baseada na ferramenta Cycles, houve a necessidade de fazer algumas adaptações na arquitetura dessa ferramenta. Assim, a arquitetura apresentada na Figura 4.1 é uma arquitetura estendida da ferramenta Cycles para apoiar os Jogos de Empresas. A ferramenta de apoio a jogos possui três módulos principais destinados a diferentes tipos de usuários: o módulo do administração, o módulo do coordenação e o módulo do jogo. O módulo do administração é utilizado pelo administrador da ferramenta para gerenciamento de usuários. Neste módulo o administrador pode inserir, excluir ou alterar dados de usuários da ferramenta.

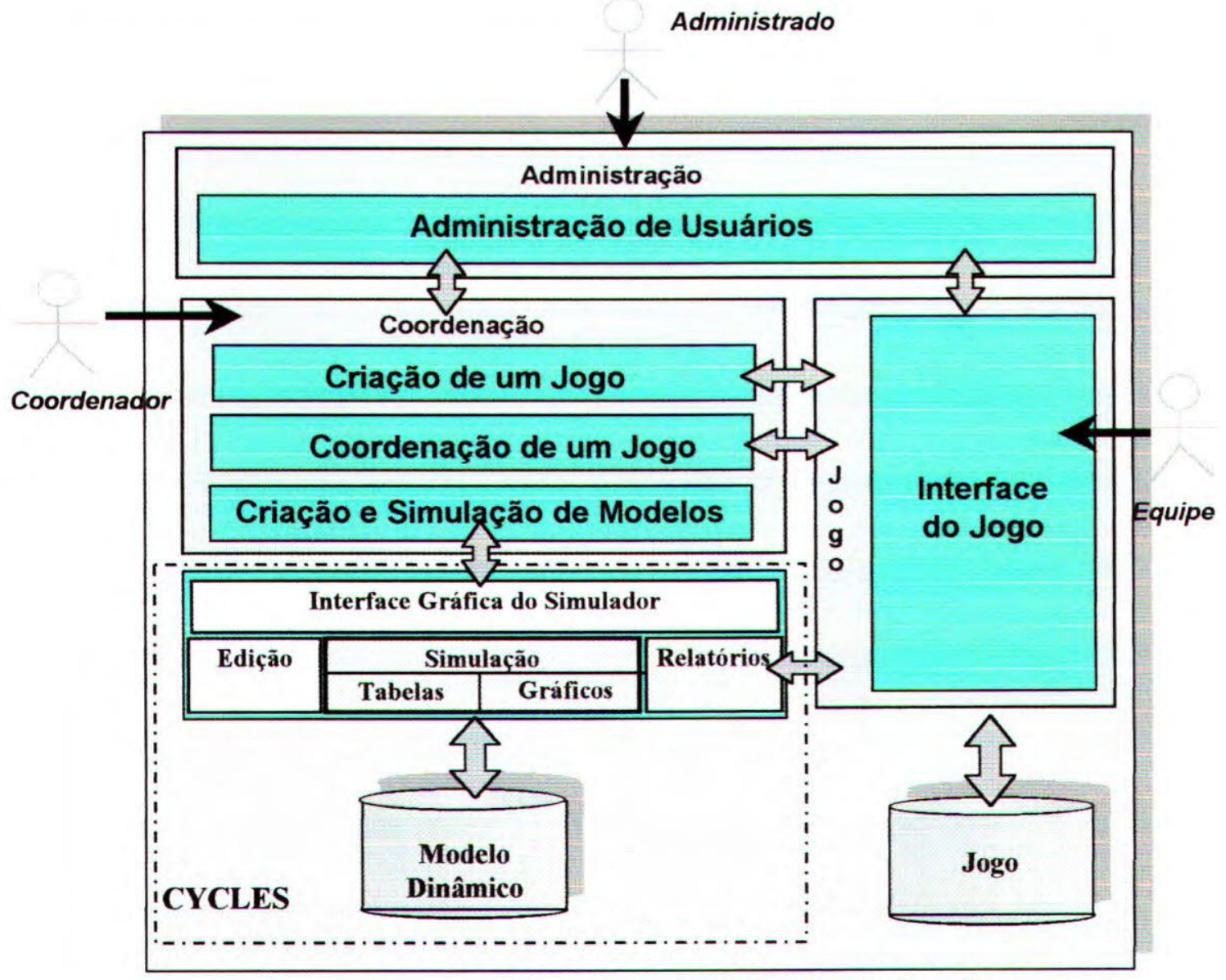

Figura 4.1 - Arquitetura da Ferramenta de Apoio a Jogos

De acordo com a Figura 4.1 o módulo de coordenação é subdividido em três submódulos:

- Criação de um Jogo,

- Coordenação de um Jogo, e

- Criação e Simulação de Modelos. 
$\mathrm{Na}$ criação e simulação de modelos dinâmicos o sistema faz uma chamada para o código executável da ferramenta Cycles. Desta maneira, somente o coordenador é capaz de editar e simular novos modelos dinâmicos ou então alterar modelos antigos que poderão ser utilizados na criação de jogos.

No sub-módulo de criação de um jogo o coordenador pode criar novos jogos e excluir ou alterar dados referentes a outros jogos criados por ele. Para criar um novo jogo o coordenador deve antes já ter estudado e estruturado a aplicação desse jogo para então definir todos os seus dados: nome do jogo; o modelo dinâmico em que será baseado; as variáveis iniciais, alteráveis e visíveis às equipes; o número de equipes; o número de períodos e a periodicidade. As variáveis iniciais, alteráveis e visíveis são classificadas e nomeadas desta maneira para facilitar o entendimento das equipes que não têm conhecimento do modelo dinâmico em que o jogo esta sendo baseado. Mas na verdade, as chamadas variáveis são componentes desse modelo e podem ser representações de níveis ou constantes. As variáveis iniciais são aqueles componentes do modelo que deverão receber valores apenas no início do jogo. As variáveis alteráveis são aquelas que poderão ser alteradas pelas equipes no ińcio de cada rodada do jogo a partir da análise dos resultados obtidos em rodadas anteriores. As variáveis visíveis não podem ser alteradas, são apenas visíveis às equipes para serem analisadas e auxiliarem nas tomadas de decisão.

O sub-módulo de coordenação de um jogo é responsável pelo gerenciamento dos resultados das simulações das equipes que estão jogando. Por este sub-módulo o coordenador é capaz de analisar esses resultados no fim de cada rodada do jogo, comentar e orientar as equipes em suas tomadas de decisão.

As equipes jogadoras tomam suas decisões por intermédio do módulo dos jogadores. Primeiramente as equipes precisam escolher o jogo, que antes já deverá ter sido liberado pelo administrador, e atribuir valores iniciais para as variáveis iniciais e alteráveis definidas pelo coordenador. Após essas atribuições iniciais, a primeira rodada de simulação é executada pela ferramenta e os resultados são apresentados em tabelas e graficamente em uma nova tela. Analisando esses resultados as equipes podem tomar novas decisões para as próximas rodadas do jogo, a partir da alteração das variáveis permitidas - variáveis alteráveis.

\subsection{Extensões Realizadas}

A ferramenta desenvolvida foi projetada sob a ferramenta Cycles de forma a estendêla para permitir a criação e aplicação de jogos, além do gerenciamento de seus usuários. A especificação da ferramenta foi feita utilizando a notação da UML - Unified Modeling Language (Eriksson \& Penker, 1998). Nas seções 4.4.1, 4.4.2 e 4.4.3 são apresentados, respectivamente, a modelagem conceitual, o projeto de banco de dados e a implementação da ferramenta.

\subsubsection{Modelagem Conceitual}

O diagrama de casos de uso fornece uma maneira de descrever as interações existentes entre os usuários e o sistema, representando uma visão de alto nível da funcionalidade do sistema mediante essas interações. A Figura 4.2 apresenta o diagrama de casos de uso da ferramenta desenvolvida. 
Como pode ser observado nesse diagrama, existem três tipos de usuários que possuem funções bem definidas:

- administrador: é responsável por gerenciar os dados dos usuários da ferramenta.

- coordenador: pode realizar três funções: criar e/ou simular um modelo dinâmico, criar um jogo e coordenar um jogo.

- equipe: será responsável pela execução do jogo, cu seja, jogar. As equipes estudam o ambiente definido pelo jogo e elaboram estratégias com o objetivo de vencer o jogo.

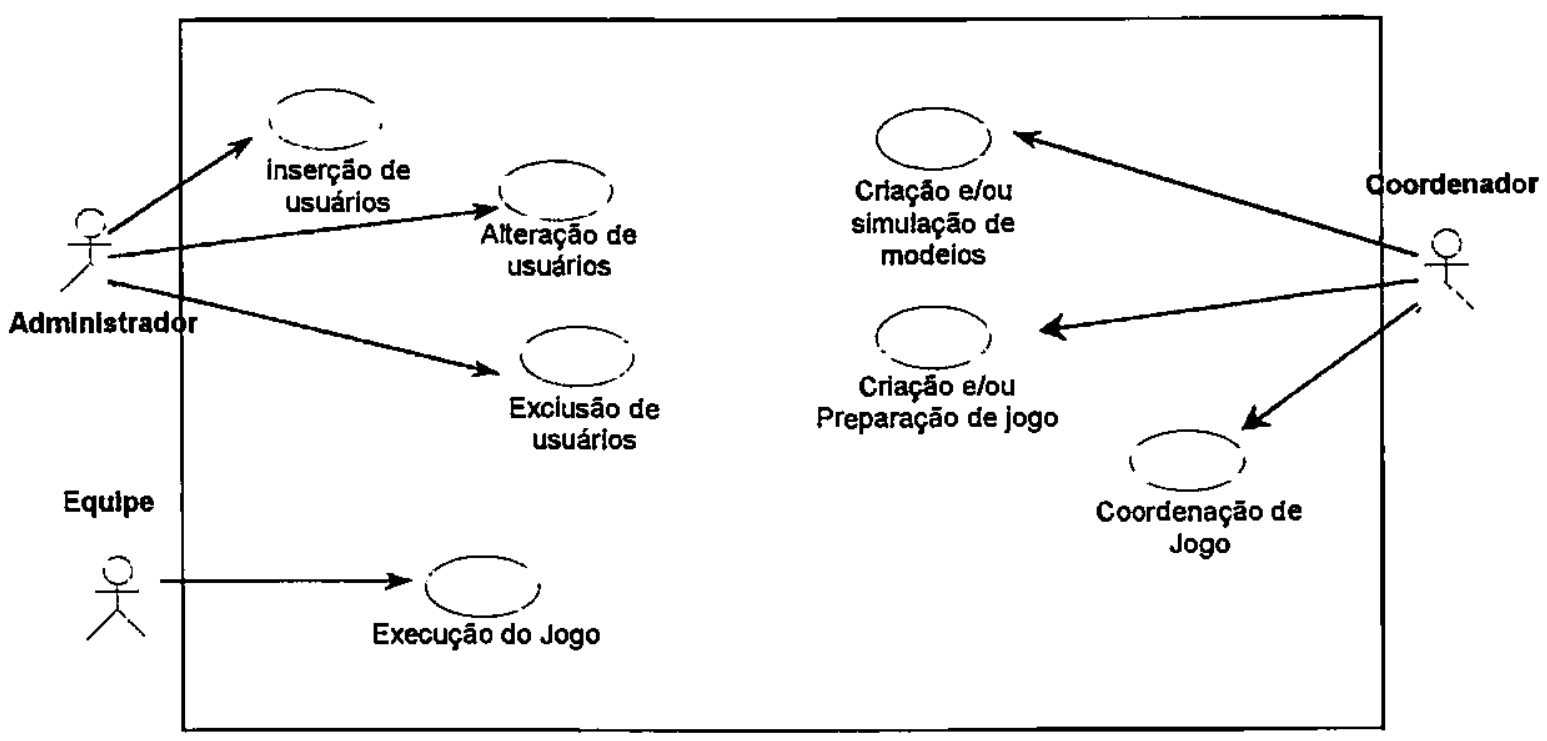

Figura 4.2 - Diagrama de Casos de Uso

O Quadro 4.1 apresenta a descrição dos casos de uso.

Quadro 4.1 - Descrição dos Casos de Uso

\begin{tabular}{|c|l|c|l|}
\hline$N^{\circ}$ & Caso de Uso & $\begin{array}{c}\text { Quem inicia } \\
\text { ação }\end{array}$ & \multicolumn{1}{|c|}{ Descrição do Caso de Uso } \\
\hline 1 & Inserção de usuários & Administrador & O administrador insere dados de novos usuários da ferramenta \\
\hline 2 & Alteracão de usuários & Administrador & O administrador altera dados de usuários da ferramenta \\
\hline 3 & Exclusão de usuários & Administrador & O administrador exclui dados de usuários da ferramenta \\
\hline 4 & $\begin{array}{l}\text { Criação ou simulação } \\
\text { de modelo }\end{array}$ & Coordenador & $\begin{array}{l}\text { O coordenador utiliza a ferramenta Cycles para criar novos modelos } \\
\text { dinâmicos ou alterar algum modelo já existente }\end{array}$ \\
\hline 5 & $\begin{array}{l}\text { Criação ou prepara- } \\
\text { cão de jogo }\end{array}$ & Coordenador & $\begin{array}{l}\text { Neste caso de uso o coordenador pode tanto criar um novo jogo ou } \\
\text { excluir os dados de um jogo já existente, como também alterar dados de } \\
\text { um jogo de forma a prepará-lo para a realizacãa de uma partida }\end{array}$ \\
\hline 6 & Coordenação de jogo & Coordenador & O coordenador gerencia a execução do jogos. \\
\hline 7 & Execução do jogo & Equipe & A equipe joga o jogo \\
\hline
\end{tabular}

A ferramenta permite a criação de jogos não interativos e funcionais. Como foi descrito no Capítulo 3, os jogos não interativos são aqueles em que as decisões de uma equipe jogadora não afetam as decisões das demais e os jogos funcionais são aqueles que simulam uma área funcional particular da empresa, sem considerar as demais áreas. Durante a aplicação do jogo a ferramenta apresenta respostas imediatas às decisões propostas pelas equipes jogadoras por intermédio de um sistema automático de processamento de decisões - simulador. Este sistema executa os cálculos e armazena todos 
os dados, sejam eles resultantes do coordenador ou das equipes jogadoras. Todos os dados relativos ao andamento do jogo são apresentados às equipes jogadoras e ao coordenador.

A aplicação do jogo deve seguir o fluxo apresentado na Figura 4.3, estabelecendo as três fases descritas no Capítulo 3: preparação, ciclo repetitivo e encerramento.

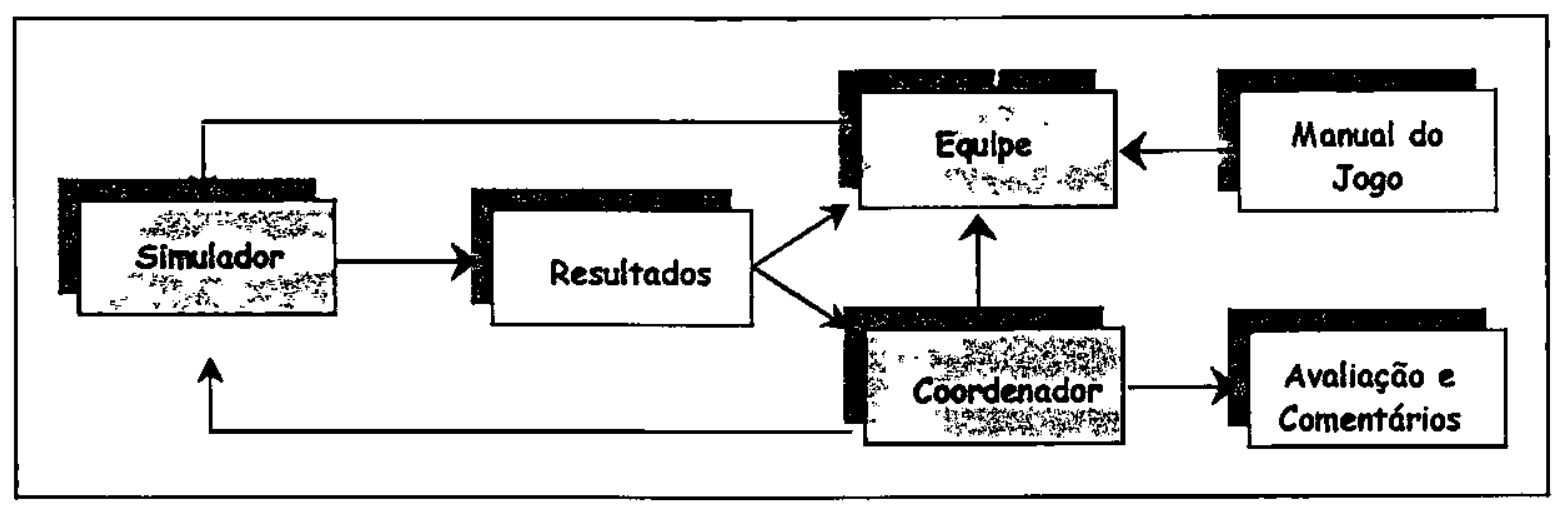

Figura 4.3 - Fluxo da Dinâmica de Aplicação do Jogo

A aplicação do jogo é quase que totalmente automatizada. Tanto o coordenador do jogo quanto cada uma das equipes deve participar da execução do jogo em um computador próprio.

Inicialmente, o coordenador, que já deve ter criado o jogo, por intermédio do Módulo de Coordenação da ferramenta, escolhe o jogo a ser executado e as variáveis do modelo que deseja visualizar durante a aplicação do jogo.

$\mathrm{Na}$ fase de preparação, o coordenador informa às equipes os objetivos e os dados do ambiente em que o jogo será desenvolvido; as decisões a serem tomadas e as regras a serem aplicadas contidas no manual do jogo. As equipes, então, se organizam, estudam o material recebido e desenvolvem suas estratégias iniciais.

No ciclo repetitivo, as equipes tomam decisões por intermédio do Módulo de Execução do jogo. A partir dessas decisões uma rodada de simulação é executada. As decisões e os resultados obtidos com a simulação são informados ao coordenador do jogo por intermédio de tabelas que este visualiza na tela de seu computador, e às equipes em forma de tabelas e gráficos. As equipes avaliam os resultados e tomam novas decisões. Este ciclo de análise de resultados e tomada de decisões é repetido por um certo número de rodadas prescrito pelo coordenador do jogo.

$\mathrm{Na}$ fase de encerramento, o coordenador do jogo juntamente com as equipes envolvidas, avalia os resultados obtidos e comenta as estratégias desenvolvidas.

A Figura 4.4 apresenta o diagrama de classes da ferramenta de apoio a jogos que foi desenvolvido a partir de uma extensão feita ao diagrama de classes da ferramenta Cycles (Garcia, 1998). 


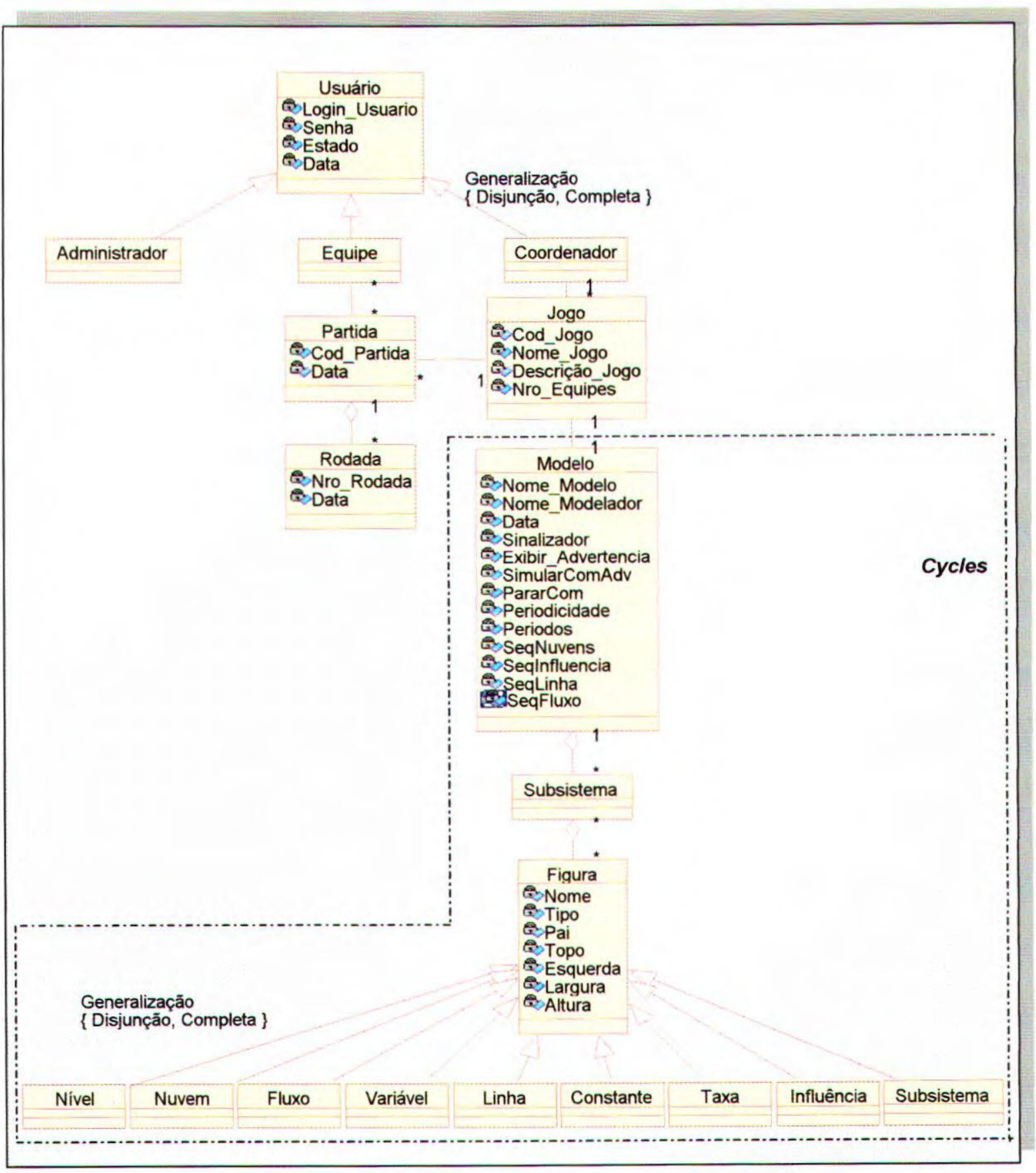

Figura 4.4 - Diagrama de Classes - Modelo Conceitual

Esse diagrama mostra a modelagem conceitual das interações entre as classes do sistema. Como pode ser observado, foram incluídas algumas classes e seus respectivos relacionamentos com as classes do modelo original da ferramenta Cycles. $\mathrm{O}$ modelo original está delimitado por um retângulo pontilhado. Foram incluídas as classes necessárias para adaptar a ferramenta Cycles para uma ferramenta destinada a criação e aplicação de jogos.

Os três tipos de usuários: administrador, coordenador e equipe são modelados no diagrama. $\mathrm{O}$ coordenador cria e gerencia um ou mais jogos que serão desenvolvidos em ambientes representados por modelos. Cada modelo, conforme especificado por Garcia (1998), é definido como um conjunto de subsistemas que podem trocar influências entre si. Cada subsistema é composto por figuras relacionadas e suas fórmulas que determinam o comportamento desse subsistema. As figuras podem ser especificadas em diferentes tipos 
conhecidos e mutuamente exclusivos: nível, nuvem, fluxo, variável, constante, taxa, influência, linha e subsistemas.

Uma equipe participa de um jogo quando inicia uma partida desse jogo. A partida do jogo é formada por uma ou mais rodadas que serão analisadas pela equipe e peio coordenador. Cada equipe pode jogar várias partidas, não simultâneas, e cada partida de um jogo envolve uma ou mais equipes jogadoras.

A Figura 4.4 não mostra os relacionamentos entre os tipos de figuras (Nivel, Nuvem, Fluxo, etc.). Entretanto, esses relacionamentos podem ser encontrados na dissertação de Garcia (1998).

\subsubsection{Aspectos de Projeto da Base de Dados}

Uma nova modelagem da base de dados foi proposta para a ferramenta Cycles, de forma a atender as necessidades da ferramenta de apoio a jogos. Assim, a Figura 4.5 apresenta o modelo entidade-relacionamento estendido da base de dados desenvolvida para a nova ferramenta.

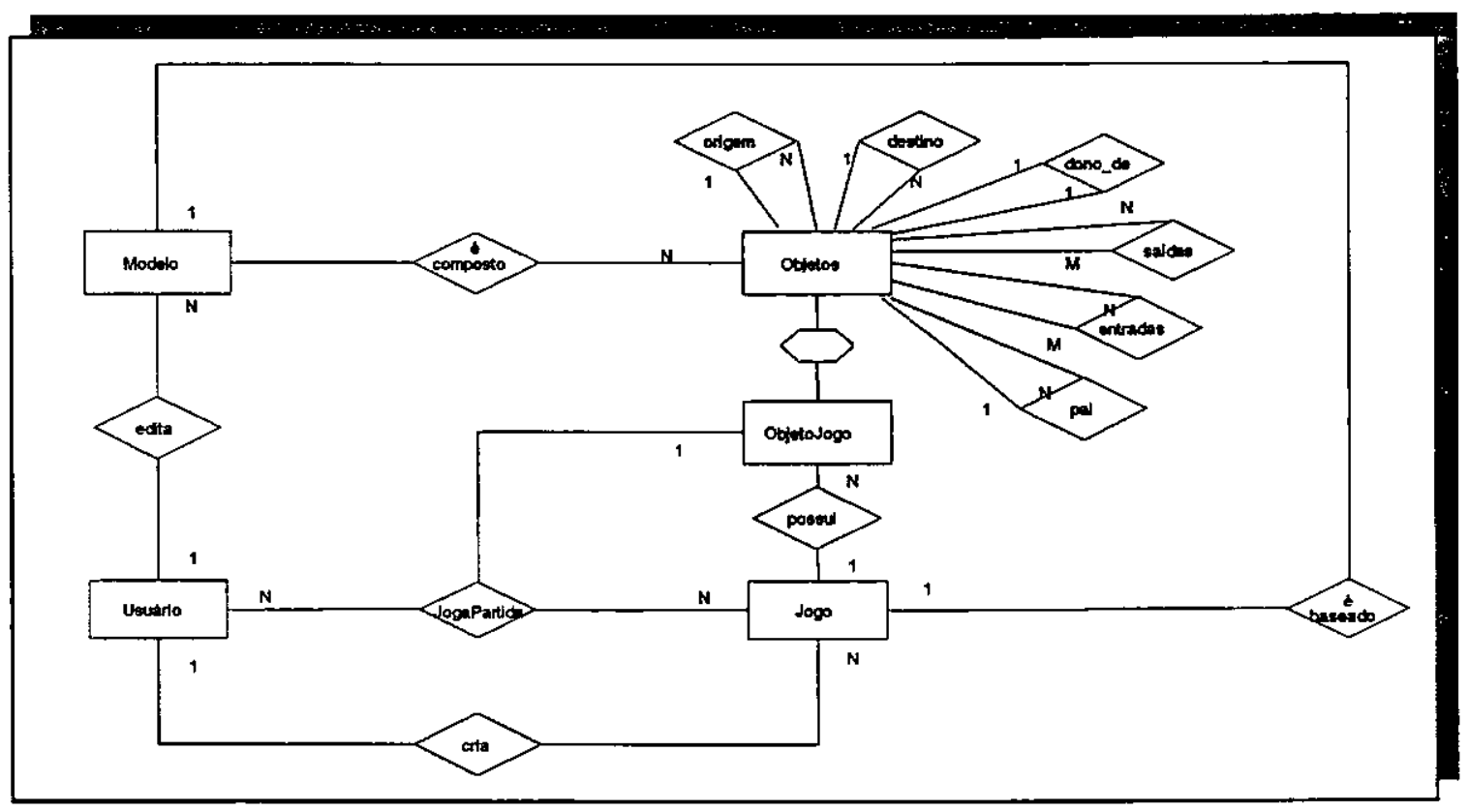

Figura 4.5 - Modelo Entidade-Relacionamento

A parte da figura que esta delimitada por um retângulo corresponde a modelagem da base de dados desenvolvida para a ferramenta Cycles (Garcia, 1998).

A partir do modelo entidade-relacionamento apresentado na Figura 4.5 foi desenvolvido o mapeamento relacional resultando nas tabelas que compõem o Quadro 4.2. 
Quadro 4.2 - Tabelas

\begin{tabular}{|c|c|c|}
\hline & Tabelas & Atributos \\
\hline 1 & Modelo & $\frac{\{\text { Nome Modelo, Responsavel, Data, Flag, ExibirAdv, SimularComAdv, PararCom, }}{\text { Periodicidade, Periodos, SeqNuvem, SeqInflue, SeqLinha, SeqFluxo }\}}$ \\
\hline 2 & Objetos & $\begin{array}{l}\text { \{ Nome Modelo, Nome_Objeto, Comentario, Tipo, Pai, Expressao, Valor, Topo, } \\
\text { Esquerda, Dono_De, Altura, Largura, Direcao, Origem, Destino \} }\end{array}$ \\
\hline 3 & Entradas & $\{$ Nome Modelo, Nome Objeto, Nome_Entrada, Tipo \} \\
\hline 4 & Saídas & $\{$ Nome_Modelo, Nome_Objeto, Nome_Saida, Tipo \} \\
\hline 5 & L suario & 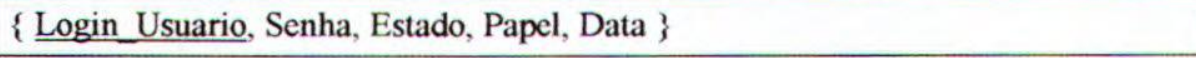 \\
\hline 6 & Jogo & $\begin{array}{l}\{\text { Cod Jogo, Nome_Jogo, Descricao, Nome_Modelo, Ustario, Numero_Rodadas, } \\
\text { Numero_Usuarios, Duracao, Flag, Data }\}\end{array}$ \\
\hline 7 & ObjetoJogo & $\{$ Nome Modelo, Nome Objeto, Cod Jogo, Classificacao \} \\
\hline 8 & JogoPartida & $\{$ Cod Partida, Nome Modelo, Nome Objeto, Cod_Jogo, Lsuano, Rodada, Valor $\}$ \\
\hline
\end{tabular}

Segundo a modelagem apresentada na Figura 4.5 e no Quadro 4.2, um Jogo é baseado em um modelo que possui vários objetos de jogo, que representam seus componentes, ou seja, suas variáveis. A tabela ObjetoJogo, originada de uma especialização da tabela Objetos, tem um atributo chamado Classificação que armazena para cada objeto de jogo (variável) sua classificação, que pode receber os valores: inicial, alterável e visível. A tabela Jogo, além de armazenar os dados de um jogo, também armazena no atributo Usuário o nome do responsável pela sua criação e no atributo Flag os valores: Ativo, Inativo ou Pronto, que representam o estado de um jogo. Se o valor do atributo Flag for Ativo ou Inativo, significa que o jogo está sendo executado ou não, respectivamente; se o valor do atributo Flag for Pronto, significa que este jogo esta preparado para ser reiniciado. Este atributo é necessário para auxiliar o o coordenador a controlar quando um jogo pode ser iniciado ou reiniciado pelas equipes.

A tabela Usuário armazena todos os dados necessários dos usuários da ferramenta. Além dos atributos básicos, esta tabela apresenta dois outros atributos responsáveis pela classificação do Estado e do Papel de cada usuário. O atributo Estado pode receber os valores : Ativo ou Inativo, que dizem se o usuário esta ou não ativo. $\mathrm{O}$ atributo Papel representa o papel que cada usuário pode exercer ao executar a ferramenta e pode receber os valores: Coordenador, Administrador e Equipe. Esse atributo implementa a generalização modelada no Diagrama de Classes apresentado na Figura 4.4.

A tabela JogaPartida surgiu do relacionamento ternário entre as tabelas Usuário, Jogo e ObjetoJogo e armazena todos os dados de cada rodada das equipes jogadoras durante a execução de uma partida de jogo. Para isso, dentre vários atributos, possui um atributo para armazenar o número da rodada - Rodada - e outro para armazenar os valores de cada variável do jogo em todas as rodadas - Valor.

As tabelas Entradas e Saídas surgiram do mapeamento de relacionamentos binários entre essas tabelas e a tabela Objetos, em que um objeto recebe influência (entradas) de um ou mais objetos e exercem influências (saidas) em um ou mais objetos.

Para modelar e armazenar essas tabelas foi utilizado o Microsoft Access 97. A Figura 4.6 apresenta os relacionamentos entre as tabelas. 


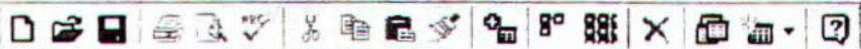

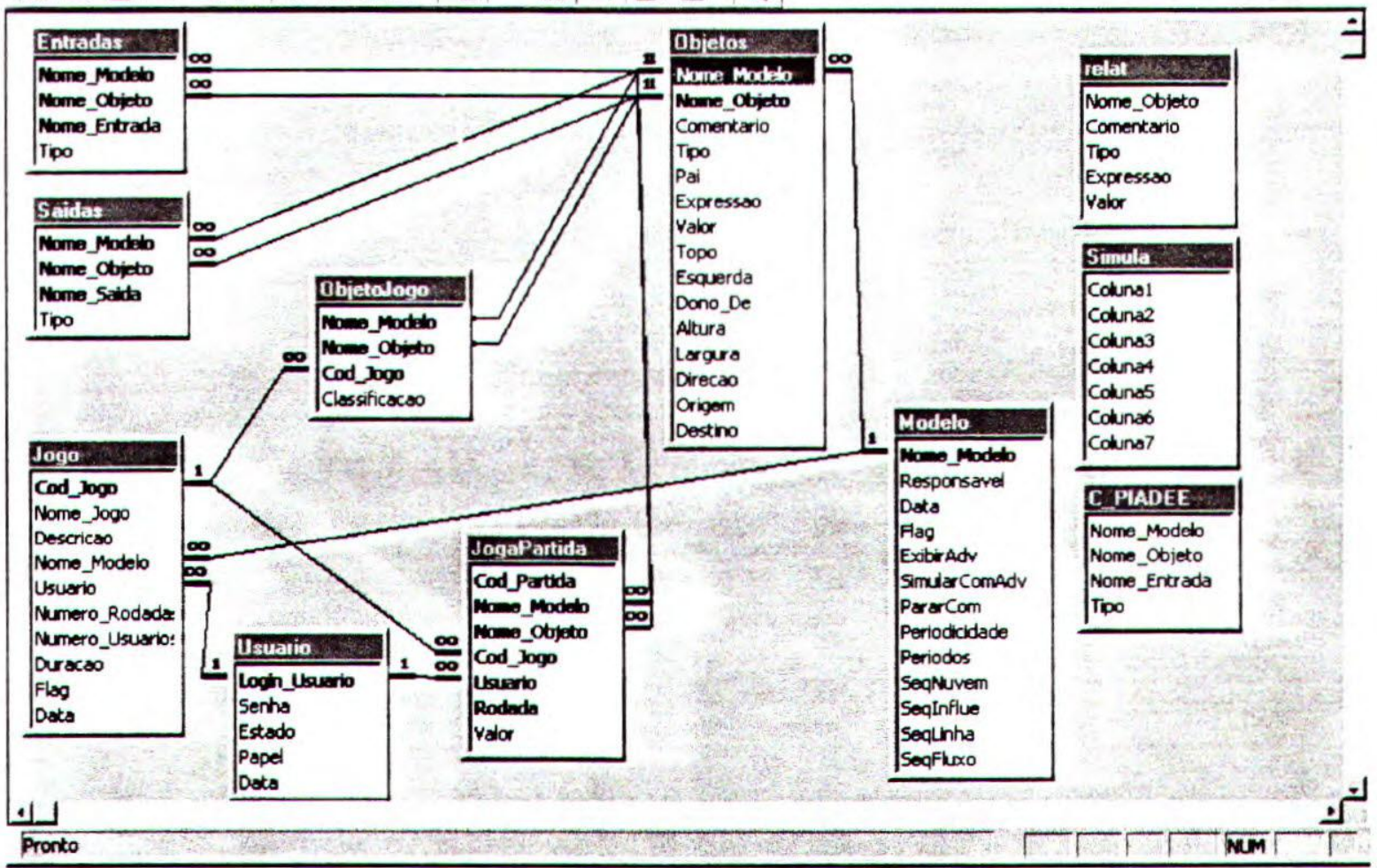

Figura 4.6 - Relacionamentos entre as Tabelas - MS Access 97

Para a implementação dessas tabelas relacionais foram utilizados os tipos de dados básicos permitidos pelo Microsoft Access. Os Quadros 4.3, 4.4, 4.5 e 4.6 apresentam as estruturas dessas tabelas.

Quadro 4.3 - Tipos de Dados da Tabela Jogo

\begin{tabular}{|l|c|c|}
\hline \multicolumn{3}{|c|}{ Tabela: Jogo } \\
\hline \multicolumn{1}{|c|}{ Atributo } & Tipo no Access & Tamanho \\
\hline Cod_Jogo & AutoNumeração & \\
\hline Nome_Jogo & Texto & 20 \\
\hline Descricao & Texto & 30 \\
\hline Nome_Modelo & Texto & 30 \\
\hline Usuario & Texto & 10 \\
\hline Numero_Rodadas & Numero & \\
\hline Numero_Usuarios & Numero & \\
\hline Duracao & Numero & \\
\hline Flag & Texto & 15 \\
\hline Data & Data/Hora & \\
\hline
\end{tabular}


Quadro 4.4 - Tipos de Dados da Tabela Usuario

\begin{tabular}{|l|c|c|}
\hline \multicolumn{3}{|c|}{ Tabela: Usuario } \\
\hline \multicolumn{1}{|c|}{ Atributo } & Tipo no Access & Tamanho \\
\hline Login_Usuario & Texto & 10 \\
\hline Senha & Texto & 8 \\
\hline Estado & Texto & 8 \\
\hline Papel & Texto & 20 \\
\hline Data & Data/Hora & \\
\hline
\end{tabular}

Quadro 4.5 - Tipos de Dados da Tabela ObjetoJogo

\begin{tabular}{|l|c|c|}
\hline \multicolumn{3}{|c|}{ Tabela: ObjetoJogo } \\
\hline \multicolumn{1}{|c|}{ Atributo } & Tipo no Access & Tamanho \\
\hline Nome_Modelo & Texto & 30 \\
\hline Nome_Objeto & Texto & 20 \\
\hline Cod_Jogo & Numero & \\
\hline Classificacao & Texto & 15 \\
\hline
\end{tabular}

Quadro 4.6 - Tipos de Dados da Tabela JogaPartida

\begin{tabular}{|l|c|c|}
\hline \multicolumn{3}{|c|}{ Tabela: JogaPartida } \\
\hline Atributo & Tipo no Access & Tamanho \\
\hline Cod_Partida & AutoNumeracao & \\
\hline Nome_Modelo & Texto & 30 \\
\hline Nome_Objeto & Texto & 20 \\
\hline Cod_Jogo & Numero & \\
\hline Usuario & Texto & 10 \\
\hline Rodada & Numero & \\
\hline Valor & Numero & \\
\hline
\end{tabular}

\subsubsection{Aspectos de Implementação e da Interface da Ferramenta}

A implementação da ferramenta proposta foi feita utilizando o ambiente $\mathrm{C}++$ Builder Enterprise - Borland, Versão 4.0 e o gerenciador de banco de dados relacional Access 97 Microsoft. Esta ferramenta deve ser executada em microcomputadores com sistema operacional Windows 95 ou Windows NT interligados em rede. 
Inicialmente, a ferramenta identifica o tipo de usuário por meio de uma interface de entrada de dados, apresentada na Figura 4.7, que requer o nome e a senha desse usuário. Essa identificação é necessária para que seja apresentada em seguida a interface correspondente ao tipo de usuário que esta usando a ferramenta. Dessa maneira, o usuário só terá acesso às funcionalidades destinadas ao seu papel durante a execução da ferramenta.

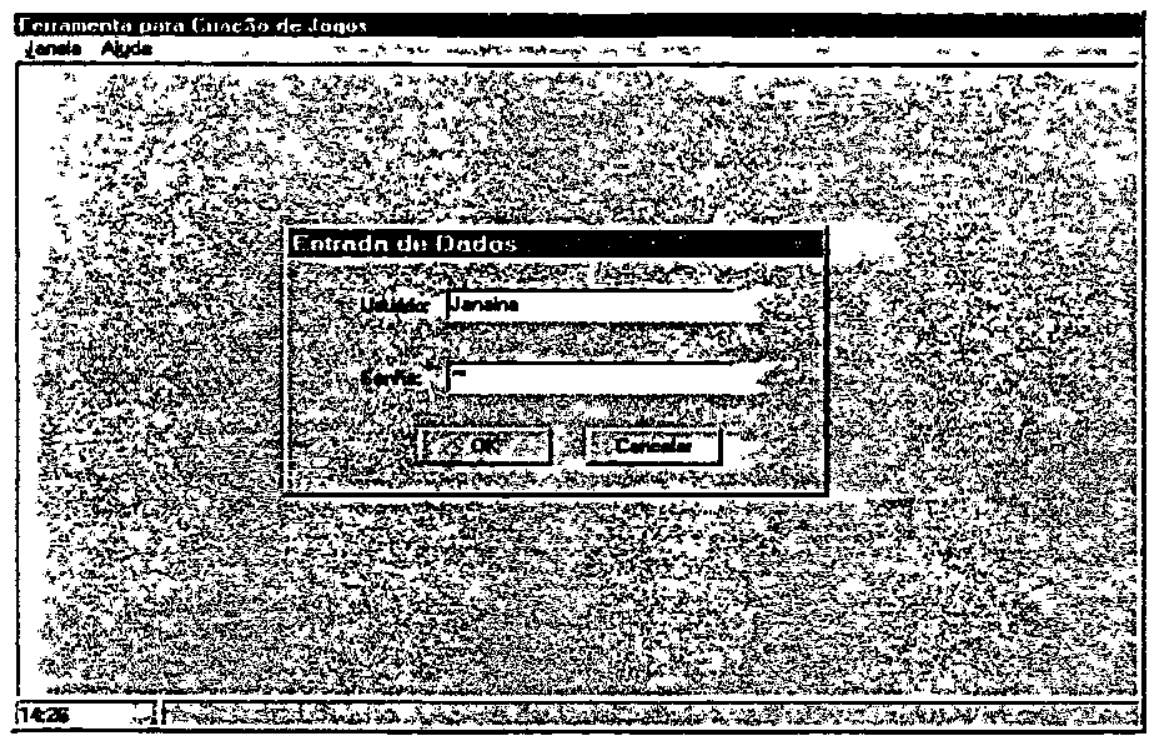

Figura 4.7 - Interface de Início da Ferramenta

Ao administrador será apresentada uma interface correspondente ao gerenciamento de usuários da ferramenta. Este poderá incluir, alterar ou excluir dados de usuários, que são armazenados na tabela Usuário da base de dados apresentada na seção anterior, pela interação com a interface da Figura 4.8.

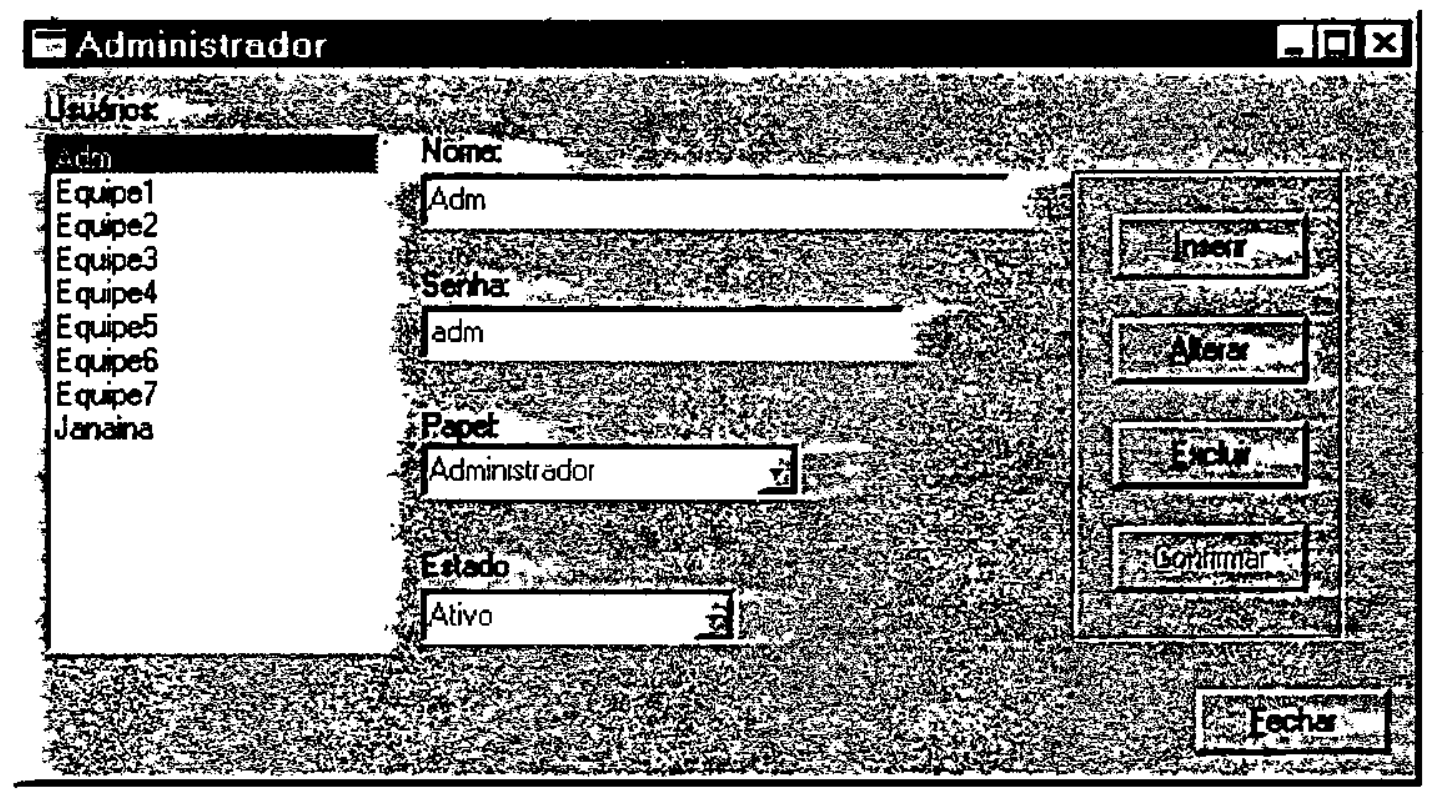

Figura 4.8 - Interface do Administrador 
O coordenador, feita sua identificação, poderá escolher uma das três opções de funcionalidades apresentadas na Figura 4.9 que são: criar e/ou simular um modelo dinâmico; criar e/ou preparar um jogo e coordenar a partida de um jogo.

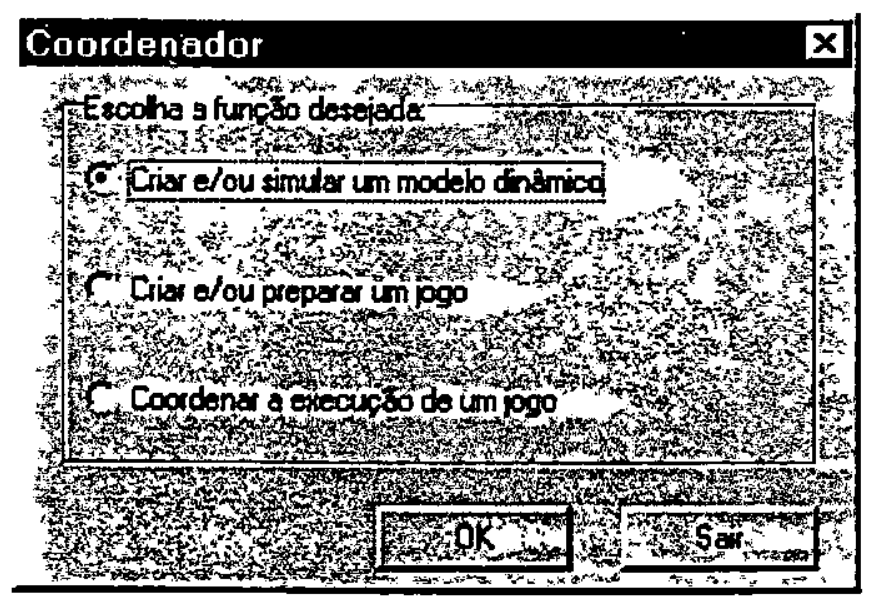

Figura 4.9 - Interface do Coordenador

Ao escolher a primeira op̧̧ão o coordenador poderá criar e/ou simular um modelo dinâmico a partir da Cycles, pois esta opção faz chamada para o código executável da ferramenta Cycles. Neste caso, apenas os dados do modelo dinâmico são armazenados na base de dados nas tabelas: Modelo, Objetos, Entradas e Saidas, apresentadas na seção anterior, enquanto que os resultados gerados nas simulações são perdidos após terminada a simulação.

A segunda op̧̧ão de funcionalidade é utilizada quando o coordenador deseja criar ou preparar um jogo para ser executado por ele e por equipes jogadoras. Ao criar ou preparar um jogo todos os dados desse jogo (número de equipes, número de rodadas, duração da partida, etc.) são armazenados ou recuperados nas tabelas Jogo e ObjetoJogo. A Figura 4.10 mostra a interface apresentada ao coordenador em que este pode incluir um novo jogo e alterar, excluir ou ver detalhes dos jogos criados por ele e apresentados em forma tabular.

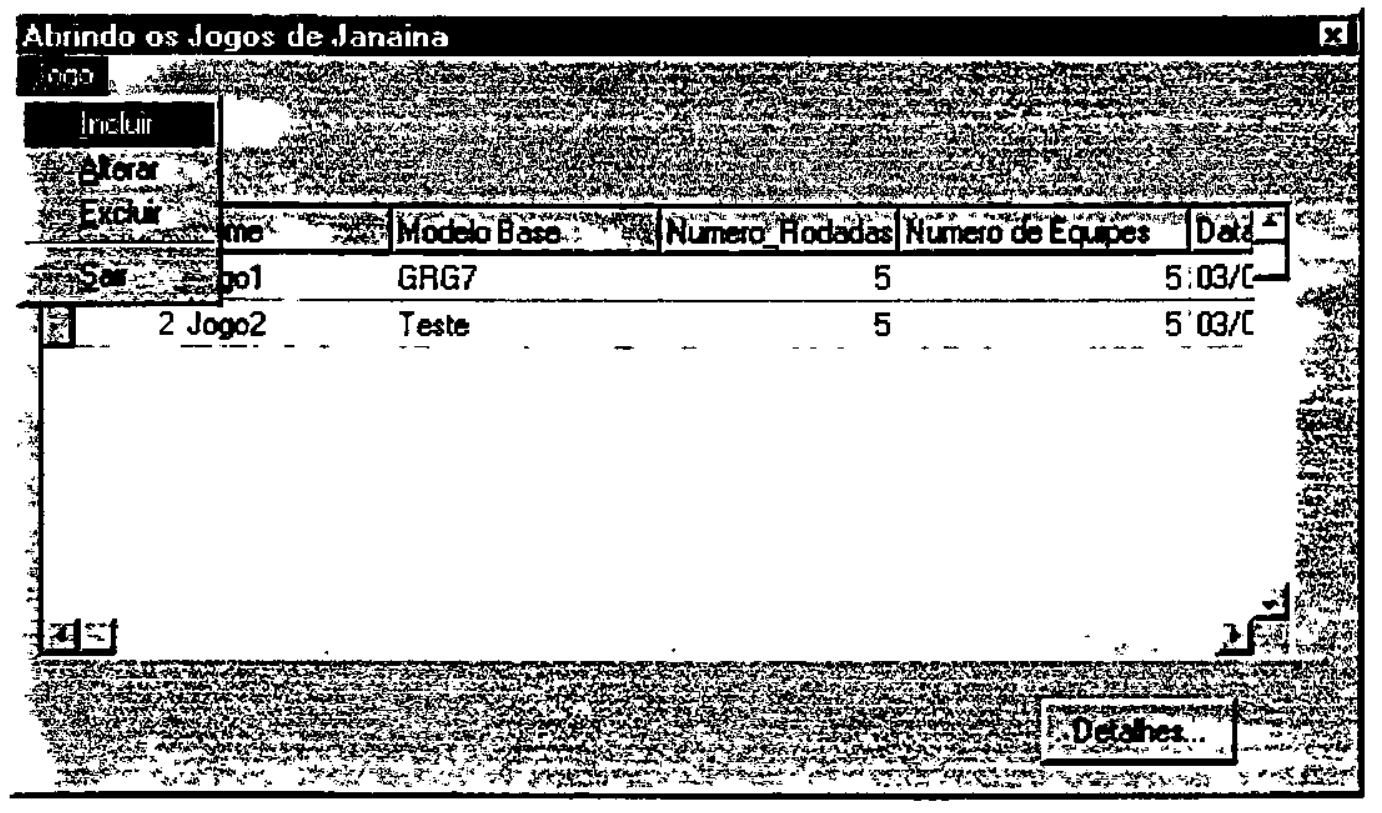

Figura 4.10 - Interface do Coordenador (Criar e/ou preparar um jogo) 
Finalmente, a terceira opção é escolhida quando o coordenador deseja gerenciar a execução de um jogo. Para isso, primeiramente o coordenador deve escolher o jogo a ser executado e as variáveis que deseja visualizar em uma tabela. Assim, por meio de tabelas o coordenador é capaz de acompanhar e analisar os resultados obtidos por cada equipe jogadora durante a execução do jogo. No entanto, para possibilitar este acompanhamento dos resultados das equipes, estas e o coordenador deverão estar executando o jogo escolhido pelo coordenador simultaneamente em microcomputadores separados interligados em rede.

Quando o coordenador escolhe um jogo, o atributo Flag da tabela Jogo, que inicialmente possui o valor 'Inativo', recebe o valor 'Ativo' indicando que este jogo esta liberado para ser executado. As equipes só conseguem dar início a uma partida de jogo quando esse atributo Flag da tabela Jogo possui os valores 'Ativo' ou 'Pronto'(explicado mais adiante), caso contrário, elas receberão um aviso dizendo para esperarem as instruções do coordenador.

Ao dar início a uma partida de jogo as equipes terão um tempo, pré-determinado pelo coordenador, para executar essa partida. Uma partida envolve várias rodadas em que as equipes deverão tomar decisões sobre variáveis do jogo, jogar e analisar os resultados. A cada rodada simulada pelas equipes são armazenados na tabela JogaPartida os valores de todas as variáveis envolvidas no jogo. É por meio de uma pesquisa feita nessa tabela que a ferramenta recupera e apresenta os resultados obtidos por cada equipe na interface do coordenador enquanto o jogo esta sendo executado.

A Figura 4.11 mostra a interface apresentada a uma equipe.

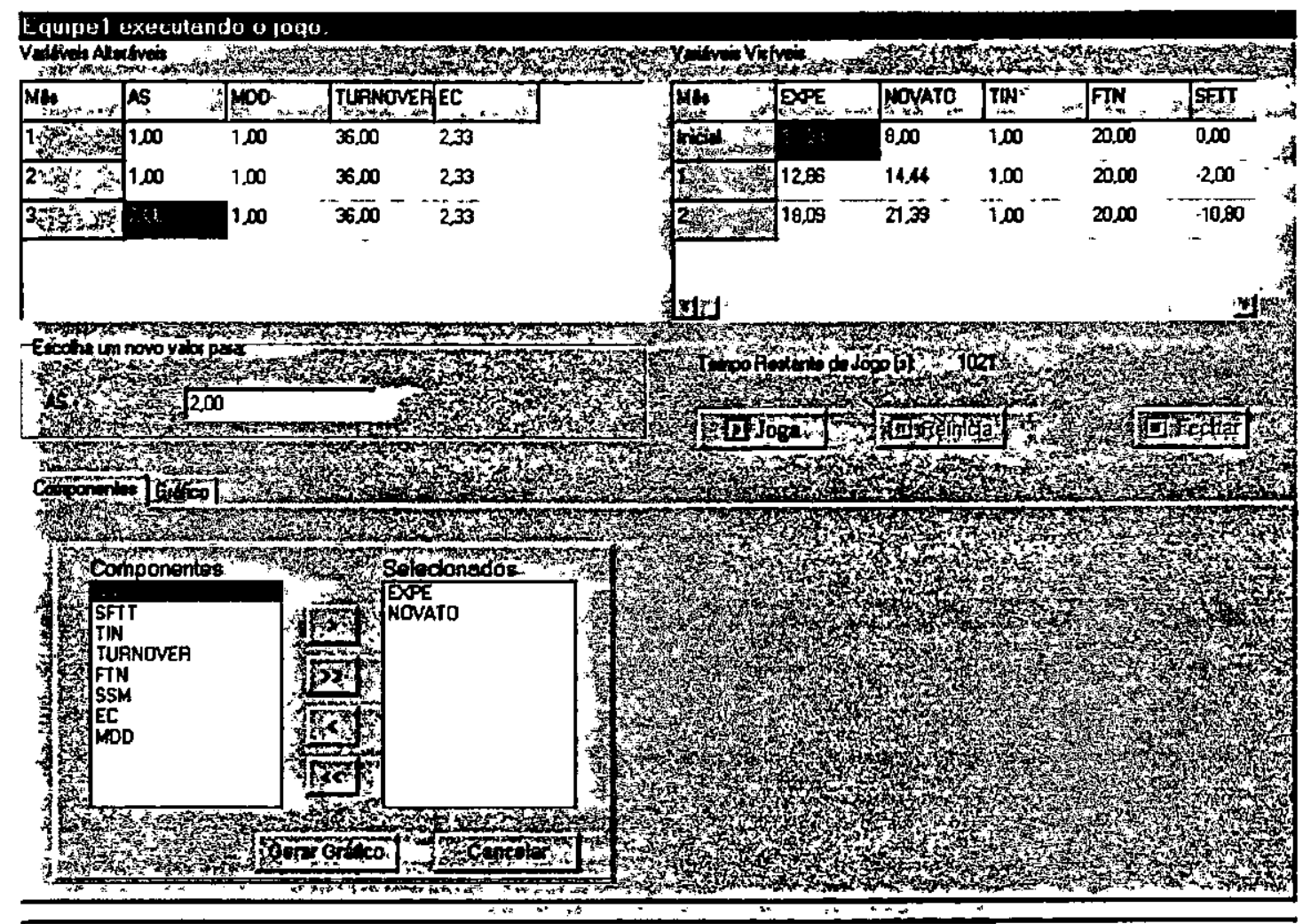

Figura 4.11 - Interface das equipes jogadoras 
Nesta interface pode-se observar que há duas tabelas: a tabela de variáveis alteráveis (à esquerda) e a tabela de variáveis visiveis (à direita). Os dados dessas duas tabelas são analisados pela equipe mas só é permitido à equipe alterar os dados da última linha da tabela de variáveis alteráveis. Ao selecionar o campo da tabela correspondente à variável que deseja alterar o valor, imediatamente o nome da variável e seu valor são apresentados em um quadro logo abaixo à tabela onde o novo valor deve ser inserido. Logo ao lado desse quadro são apresentados o tempo restante de jogo (em segundos), que a parair do inicio da partida está sendo decrementado, e os botões : Joga, Reinicia e Finaliza, usados, respectivamente, para jogar, reiniciar uma partida ou finalizar o jogo. Na parte inferior da tela pode-se visualizar em um gráfico o andamento das rodadas do jogo.

Caso uma equipe não consiga terminar a partida do jogo no tempo pré-determinado, ela recebe uma mensagem e fica impossibilitada de continuar jogando.

No fim da execução de uma partida do jogo o coordenador analisa e avalia, juntamente com as equipes, as estratégias desenvolvidas por estas. Logo após, o coordenador finaliza a execução de uma partida e os dados armazenados na tabela JogaPartida são apagados. Além disso, o coordenador deve decidir se deseja finalizar o jogo ou iniciar uma nova partida. No primeiro caso, o atributo Flag da tabela JogaPartida recebe o valor 'Inativo', no segundo caso este atributo recebe o valor Pronto e as equipes poderão reiniciar o jogo. Desta forma, as equipes só poderão reiniciar um jogo com a permissão do coordenador.

\subsection{Considerações Finais}

Neste capítulo foram apresentadas as adaptações feitas na ferramenta Cycles, a nova arquitetura e as extensões realizadas para o desenvolvimento da ferramenta de apoio a jogos: analise de requisitos, modelo de dados, aspectos de projeto e de implementação. Além disso, foram apresentadas as funcionalidades da ferramenta e suas interações com a base de dados. Feita esta descrição, no próximo capitulo é apresentado em detalhes todo o procedimento necessário para se criar um novo jogo e executá-lo com duas equipes. 


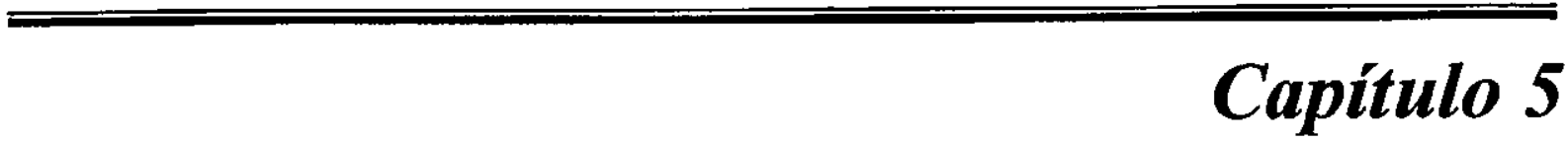

Um Jogo para Gestão de RH em Projetos de Software 


\subsection{Considerações Iniciais}

Este capitulo apresenta a dinâmica da execução de uma partida de jogo utilizando a ferramenta desenvolvida de apoio a jogos. Para exemplificar a utilização da ferramenta foi desenvolvido um jogo de empresa baseado no modelo dinâmico do subsistema de gerenciamento de recursos humanos apresentado nc capítulo 2. Assim, a seção 5.2 apresenta as alterações realizadas no modelo dinâmico original; a seção 5.3 apresenta o jogo desenvolvido, suas características, seus objetivos e variáveis envolvidas. A seção 5.4 apresenta o processo necessário para criação do jogo e a dinâmica envolvida na aplicação do jogo.

\subsection{O Modelo Dinâmico Alterado}

Como foi apresentado anteriormente, o processo de gestão de projetos de software pode ser dividido em quatro subsistemas: recursos humanos, produção de software, controle e planejamento (Hamid \& Madnick, 1991). No entanto, devido à complexidade desse processo, este trabalho abordará apenas o desenvolvimento de um jogo baseado no modelo do subsistema de gerenciamento de recursos humanos. Este subsistema envolve as atividades de contratação, treinamento, assimil ação e transferência de recursos humanos entre projetos de uma empresa de desenvolvimento de software. Para tornar esse modelo adequado aos objetivos do jogo houve a necessidade de fazer algumas alterações no modelo original. A Figura 5.1 apresenta o modelo, baseado na Dinâmica de Sistemas, com as alterações realizadas na cor azul.

Foram acrescentados dois níveis: Somatória de Força de Trabalho Total e Somatória do Salório Mensal, que representam, respectivamente, uma somatória do número total de força de trabalho alocada a um projeto e do valor mensal de uma certa unidade monetária gasta com pagamento de salários às Forças de Trabalhos de Novatos e Experientes. As constantes Ajuste Salarial e Salário representam, respectivamente, o aumento e um valor base para o salário das forças de trabalho e exercem influencia nas taxas de Soma do Salário dos Novatos e Soma de Salário dos Experientes. A Somatória da Força de Trabalho Total irá auxiliar as equipes que participarão de um jogo a visualizarem o total acumulado de força de trabalho que está sendo requerido em cada período de desenvolvimento do projeto.

O cálculo da Taxa de Saída também foi alterado. Agora o Ajuste Salarial exerce influencia sobre o tempo em que um empregado permanece no emprego. Quando ocorre um aumento no salário de um empregado, este tende a permanecer mais tempo no emprego e consequentemente a Taxa de Saida será menor.

Outra alteração feita no modelo original foi no cálculo da Força de Trabalho Total. Esta variável, antes calculada pela soma das Forças de Trabalho de Novatos e Experientes, agora recebe influencia da variável Treinamento Diário por Funcionário, que representa a força de trabalho de novatos que está sendo treinada pelos experientes. Sendo os Experientes os funcionários responsáveis pelo treinamento dos Novatos a Força de Trabalho Total do projeto será decrementada. 


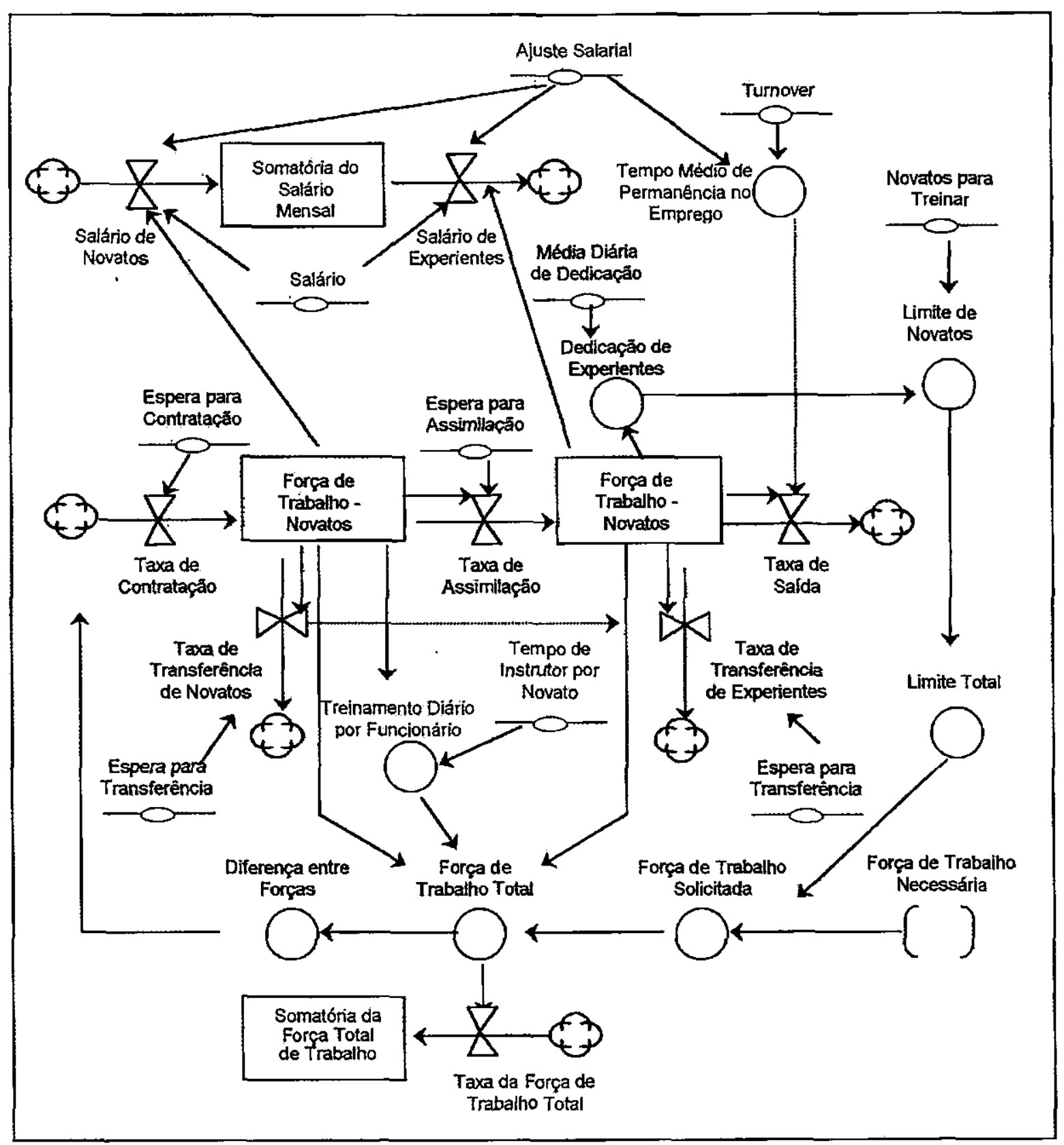

Figura 5.1 - Modelo de Gerenciamento de Recursos Humanos Modificado

As expressões que representam todos os componentes do modelo exposto são apresentadas na Tabela 5.1.

Tabela 5.1- Valores Iniciaîs e Expressōes do Modelo

\begin{tabular}{|c|c|}
\hline Componentes do Modelo & Expressōes e Valores Iniciais \\
\hline Tempo de Instrutor por Novato & 3.20 \\
\hline Média Diária de Dedicaçs̆o & 1 \\
\hline Espera para Contrataçäo & 1.33 meses \\
\hline Espera para Assimilaçāo & 2.67 meses \\
\hline Tempo Médio de Permanência no Emprego & Turnover * Ajuste Salarial \\
\hline Espera para Transferência & 0.33 mês \\
\hline Treinamento Diário por Funcionário & Força de Trabalho Novatos * Tempo de Instrutor por Novato \\
\hline Dedicaçāo de Experieutes & Média Diária de Dedicação * Força de Trabalho Experientes \\
\hline Limite de Novatos & Dedicaçáo de Experientes * Máximo de Novatos para Treinar \\
\hline Força de Trabalho Total & $\begin{array}{l}\text { Força de Trabalho Experientes + Força de Trabalho Novatos } / 2 \text { ) - } 2 \\
\text { Tempo Diário por Instrutor }\end{array}$ \\
\hline
\end{tabular}




\begin{tabular}{|l|l|}
\hline Limite Total & Força de Trabalho Experientes + Limite de Novatos \\
\hline Força de Trabalho Solicitada & Mínimo entre Limite Total e Força de Trabalho Necessária \\
\hline Diferença entre Forças & Força de Trabalho Solicitada - Força de Trabalho Total \\
\hline Taxa de Contrataçāo & Máximo (0, Diferença entre Forças / Espera para Contratação) \\
\hline Taxa de Assimilação & Força de Trabalho Novatos / Média de Espera para Assimilação \\
\hline Taxa de Saida & $\begin{array}{l}\text { Força de Trabalho Experientes / Tempo Médio de Permanência no } \\
\text { Emprego }\end{array}$ \\
\hline Taxa de Transferência de Novatos & $\begin{array}{l}\text { Minimo (Máximo (0, (-Diferença entre Forças / Espera para } \\
\text { Transferência)), Força de Trahalho Novatos) }\end{array}$ \\
\hline Taxa de Transferência de Experientes & $\begin{array}{l}\text { Mínimo (Força de Trabalho Experientes, Máximo(0, -Diferença } \\
\text { entre Forças / Espera para Transferência))- Taxa Transferência de } \\
\text { Novatos)) }\end{array}$ \\
\hline Força de Trabalho - Novatos & 10 \\
\hline Força de Trabalho - Experientes & 15 \\
\hline Força de Trabalho Necessária & 25 \\
\hline Turnover & 36 meses \\
\hline Ajuste Salarial & 1 \\
\hline Somatória do Salário Mensal & Salário de Novatos + Salário de Experientes \\
\hline Somatória da Força de Trabalho Total & 0 \\
\hline Taxa de Força de Trabalho Total & Força de Trabalho Total \\
\hline Salário de Novatos & Força de Trabalho Novatos*Salario*Ajuste Salarial \\
\hline Salário de Experientes & Força de Trabalho Experientes*3*Salario*Ajuste Salarial \\
\hline Salário & 1000 \\
\hline
\end{tabular}

\subsection{Jogo}

$O$ jogo simula o aspecto gerencial de recursos humanos de uma empresa de desenvolvimento de software. Cada equipe que participa do jogo deve representar o papel do gerente de projeto que será responsável por tomar decisões sobre a contratação de novas pessoas, conforme a necessidade do projeto; a promoção de pessoas recém-contratadas no projeto - novatos - em profissionais - experientes - à medida que vão adquirindo experiência; e as eventuais saídas de profissionais que pedem demissão ou se aposentam.

Do ponto de vista do gerente do projeto, os membros da equipe de desenvolvimento podem ser classificados em novatos ou experientes. Essa classificação é necessária para caracterizar a diferença de produtividade existente entre um novato e um experiente. A produtividade de um novato é, em média, $50 \%$ menor que a produtividade de um experiente. Todas as pessoas que começam a trabalhar em um projeto são consideradas novatas, pois requerem um treinamento para se familiarizar com a organização e detalhes desse projeto. Esse treinamento é oferecido pelos próprios membros experientes da equipe que acabam tendo seu tempo de produção diminuído. Entretanto, esses experientes poderão trabalhar horas-extras no projeto.

Os membros da equipe podem deixar de trabalhar no projeto por três razões: transferência para outros projetos, aposentadoria ou demissão. Essas razões que levam um membro a sair do projeto podem ser influenciadas por um ajuste salarial, ou seja, quando um membro do projeto está satisfeito com seu salário ele pode decidir não deixar o projeto. Quando há a necessidade de transferir membros da equipe, os primeiros a serem transferidos são os novatos, aqueles que ainda estão sendo treinados. Se ainda assim houver a necessidade de transferir mais pessoas, os próximos a serem transferidos são os experientes. Aqueles que estão deixando o projeto ainda permanecem um tempo trabalhando enquanto se processa a transferência.

As equipes jogadoras desconhecem o modelo dinâmico em que o jogo está sendo baseado e apenas conseguem visualizar algumas das variáveis desse modelo. Estas variáveis, visualizadas pelas equipes, são aquelas apresentadas na Tabela 5.1 na cor cinza. 


\subsubsection{Objetivo do Jogo}

O objetivo do jogo é obter o melhor desempenho no gerenciamento dos recursos humanos do projeto. Esse desempenho será avaliado pelas estratégias utilizadas pelas equipes que irão exercer o papel de gerentes de projeto. A principal meta é atingir um determinado nível de esforço aplicado ao projeto usando a medida de esforço como, por exemplo: 50 homens/mês em um tempo máximo de 5 meses.

Para atingir essa meta as equipes deverão tomar suas decisões com base nas definições de algumas variáveis classificadas nos três tipos descritos no capítulo anterior: variáveis iniciais, variáveis alteráveis e variáveis visíveis.

$\mathrm{Na}$ próxima subseção são apresentadas quais variáveis foram escolhidas pelo coordenador que é o autor do jogo para serem iniciais, alteráveis e visíveis; e uma descrição de cada uma delas.

Existem algumas variáveis que devem possuir seus valores dentro de intervalos definidos. A ferramenta não impede às equipes atribuírem valores a variáveis fora do intervalo definido. Por esse motivo, o coordenador deve deixar bem claro às equipes essas limitações e orientá-las a definirem valores corretos.

\subsubsection{Variáveis Definidas no Início do Jogo}

\section{Força de Trabalho dos Novatos (Novato)}

A Força de Trabalho de Novatos representa o número de pessoas recém-contratadas ou recém-transferidas de outros projetos internos da empresa para o desenvolvimento do projeto. $O$ gerente deve garantir a estas novas pessoas um treinamento adequado até tornalas membros experientes da equipe de produção. Para definir a Força de Trabalho de Novatos é necessário considerar o tempo em que as pessoas estarão em treinamento e a produtividade de um novato, que é $50 \%$ menor que a produtividade de um experiente.

\section{Força de Trabalho dos Experientes(Expe)}

A Força de Trabalho dos Experientes representa o número de pessoas experientes que estão trabalhando no projeto. Os experientes são os engenheiros de software experientes que começaram a trabalhar no projeto desde o início ou como novatos que foram treinados durante algum tempo até se tornarem completamente integrados ao projeto. Faz parte do trabalho do experiente treinar os novatos do projeto. Apesar do experiente ser mais produtivo que um novato, sua produtividade diminui conforme aumenta o tempo dedicado ao treinamento de novatos.

\section{Força de Trabalho Necessária (FTN)}

A Força de Trabalho Necessária representa o número de pessoas requeridas a cada mês para o desenvolvimento do projeto. Para decidir o valor desta variável o gerente deve considerar vários fatores. Um fator importante é o tempo de duração do projeto. Como parte da função de planejamento o gerente determina o número de pessoas que acredita ser necessário, a cada mês, para concluir o projeto dentro do prazo. Outro fator importante é o esforço total necessário para o desenvolvimento do projeto. 


\section{Tempo de Instrutor por Novato (TIN)}

O Tempo de Instrutor por Novato é um percentual médio que um experiente (instrutor) gasta de seu tempo de trabalho para treinar um novato. Supondo como exemplo que essa variável, Tempo de Instrutor por Novato, receba o valor 0.10 . Isto significa que a média que cada novo empregado consome em treinamento é equivalente a $10 \%$ do tempo de trabalho de um experiente.

\subsubsection{Variáveis Alteráveis Durante o Jogo}

\section{Média de Dedicação Diária (MDD)}

Nesta empresa, enquanto os novatos trabalham o tempo todo somente em um projeto, os experientes podem trabalhar em mais de um projeto ao mesmo tempo. Assim, a Média de Dedicação Diária representa a média de dedicação diária de um experiente em um projeto. Quando essa média está entre os valores 0.5 e 1, ou seja, $0.5<\mathrm{MDD}<1$, significa que o experiente trabalha MDD de seu tempo (8 horas diárias) no projeto e o resto de seu tempo em outros projetos; $\mathrm{MDD}=1$ significa que o experiente dedica todo seu tempo ao projeto; $1<\mathrm{MDD}<1,5$, significa que o experiente trabalha horas extras no projeto com tempo máximo de horas extras igual a 4 horas diárias.

\section{Espera para Contratação (EC)}

A Espera para Contratação representa um atraso de tempo. O que ocorre na maioria das empresas quando um gerente de recursos humanos precisa contratar novas pessoas para um projeto é a ocorrência de uma certa demora na seleção e recrutamento de novos engenheiros de software, pelo Departamento de Recursos Humanos. Enquanto isso o projeto tem que continuar convivendo com a falta de pessoal e o gerente deve continuar se preocupando com o prazo final do projeto. Assim, a Espera para Contratação representa o atraso de tempo, em meses, a cada rodada do jogo. Quanto menor for esse valor mais rápido as pessoas serão contratadas e, conseqüentemente, estarão disponíveis mais cedo.

\section{Ajuste Salarial (AS)}

O Ajuste Salarial representa o aumento dado aos salários dos membros do projeto. Quando o valor desta variável é 1 significa que nenhum ajuste esta sendo aplicado ao salário. Se esse valor for alterado para 1,20 por exemplo, significa que um ajuste de $20 \%$ esta sendo aplicado ao salário dos membros do projeto.

\subsubsection{Variáveis Visiveis do Jogo}

\section{Somatória da Força de Trabalho Total (SFTT)}

A Somatória da Força de Trabalho Total representa o total de força de trabalho alocada desde o início do jogo para o desenvolvimento do jogo. Essa variável é analisada pelas equipes que tentarão atingir a meta do projeto, que é o nível máximo de esforço, proposto pelo coordenador, aplicado ao projeto. A fórmula para cálculo desta somatória é:

$$
S F T T=E X P E+N O V A T O / 2-2(N O V A T O * T I N)
$$

Nesta fórmula é realizada uma soma da força de trabalho de Experientes com metade da força de trabalho de Novatos, já que, estes por serem novatos, possuem uma produção 
correspondente a metade da produção dos Experientes. Dessa soma é subtraída a porcentagem da força de trabalho (Novatos e Experientes) que permanece em treinamento.

\section{Somatória do Salário Mensal (SSM)}

A Somatória do Salário Mensal é uma variável cumulativa que representa o valor total gasto com o pagamento da força de trabalho desde o início do projeto. A fórmula para cálculo desta somatória é:

$$
\begin{aligned}
S S M= & S N+S E \text { em que: } \\
& S N=(N O V A T O * S A L A R I O B A S E) *(I+A S) \\
& S E=(E * 3 * S A L A R I O B A S E) *(I+A S)
\end{aligned}
$$

Essa variável representa uma somatória mensal cumulativa do salário pago aos novatos $(S N)$ com o salário pago aos experientes $(S E)$. O salário dos novatos é expresso pelo produto do número de força de trabalho de novatos por um salário base e pelo ajuste salarial correspondente ao mês corrente. O salário dos experientes segue o mesmo raciocínio com a diferente de que um experiente ganha três vezes mais que um novato.

\section{Força de Trabalho Total (FTT)}

A Força de Trabalho Total representa o esforço total da força de trabalho que é realmente produtiva a cada mês no desenvolvimento do projeto. Assim, as horas dedicadas a treinamento não estão inclusas nesta variável.

\subsection{Dinâmica do Jogo}

Primeiramente, antes do início da execução de um jogo algumas atividades já devem ter sido realizadas. São elas: cadastramento de usuários do jogo, construção do modelo dinâmico em que o jogo será baseado, criação e preparação do jogo. $O$ cadastramento de usuários é feito pelo administrador por meio da interface apresentada na Figura 4.8 do capítulo anterior.

Assim sendo, supondo que não exista nenhum modelo dinâmico ou jogo criado e armazenado na base de dados, é apresentado a seguir o procedimento necessário para a elaboração e execução do jogo apresentado na seção 5.3 utilizando a ferramenta desenvolvida.

\subsubsection{Procedimento para Criação de um Jogo}

O primeiro passo para a criação de um jogo baseado na Dinâmica de Sistemas é o desenvolvimento de um modelo dinâmico. Como foi dito anteriormente, neste trabalho o modelo dinâmico utilizado é aquele apresentado na seção 5.2 que descreve em detalhes o subsistema modificado de gerenciamento de recursos humanos de Hamid e Madnick (1991). Como o objetivo principal deste trabalho não é entrar em detalhes da modelagem da Dinâmica de Sistemas, foi escolhido esse subsistema para exemplificar a utilização da ferramenta desenvolvida no processo de elaboração e aplicação de um jogo. Desta forma, para obter detalhes sobre a modelagem dinâmica será necessário consultar o trabalho desenvolvido por Garcia (1998). 
O coordenador do jogo, ao escolher a opção Criar e/ou simular um modelo dinâmico da interface apresentada na Figura 5.2, tem a oportunidade de desenvolver um modelo dinâmico a partir da ferramenta Cycles.

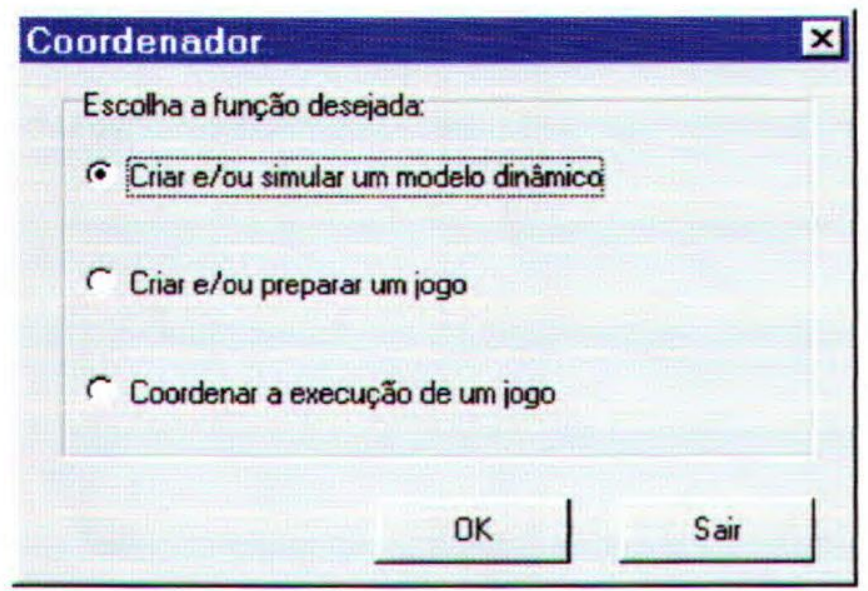

Figura 5.2 - Interface do Coordenador

Assim, quando o coordenador escolhe a função: Criar e/ou simular um modelo dinâmico o sistema realizará uma chamada ao código executável da ferramenta Cycles e a interface apresentada ao coordenador será a mostrada na Figura 5.3.

A partir dessa interface o coordenador, poderá criar e simular um modelo dinâmico. Todos os dados correspondentes ao modelo criado são armazenados em uma base de dados que mais tarde será consultada na criação do jogo. A Figura 5.3 apresenta parte do modelo dinâmico criado pelo coordenador.

Criado o modelo dinâmico o coordenador pode dar início ao processo de criação do jogo. Este processo envolve muita criatividade e conhecimento dos objetivos e necessidades pretendidos com o jogo. Assim, é necessário realizar um estudo detalhado das variáveis do modelo dinâmico e de seus inter-relacionamentos para auxiliar na elaboração do jogo e na dinâmica de sua aplicação.

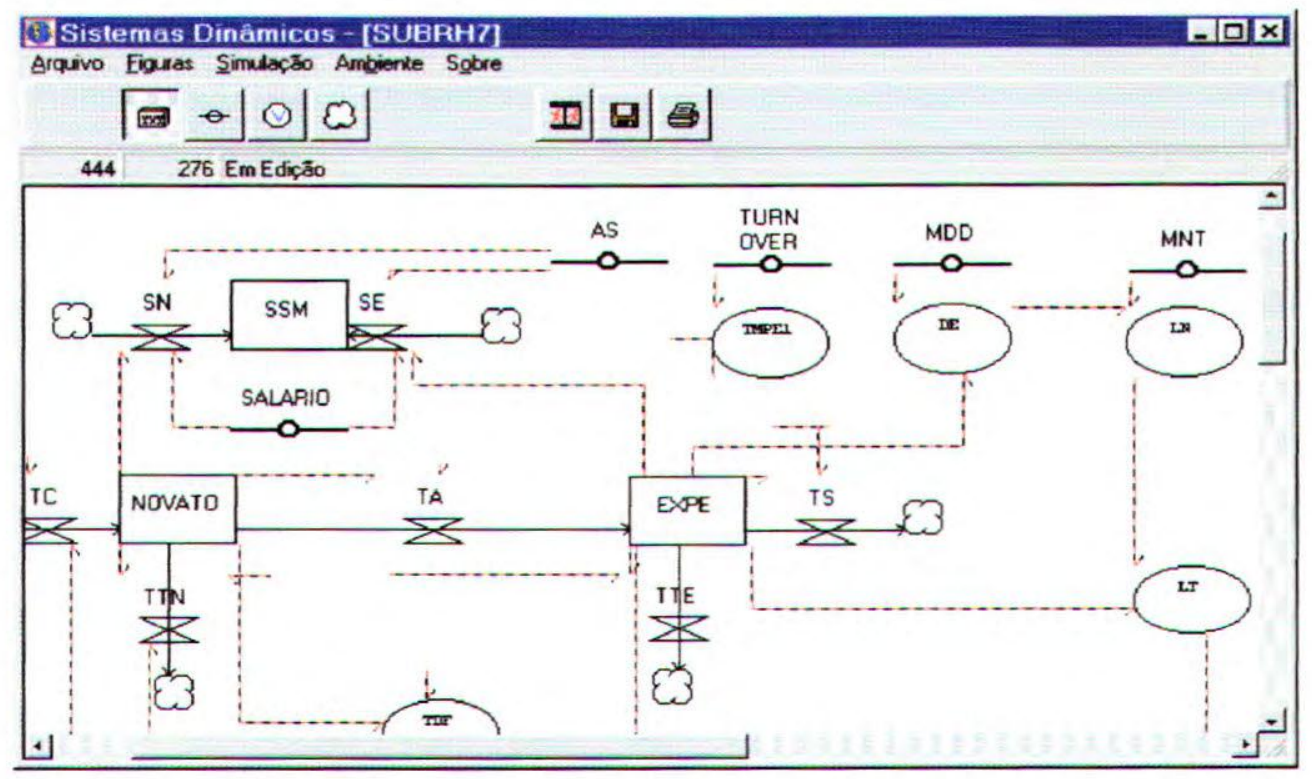

Figura 5.3 - Interface para modelagem da Dinâmica de Sistemas 
Quando o jogo já tiver sido elaborado e estruturado informalmente o coordenador deverá, pela escolha da opção: Criar e/ou preparar um jogo, incluir um novo jogo na base de dados. A Figura 5.4 apresenta a interface de inclusão de um novo jogo. Nesta figura o coordenador está incluindo o jogo apresentado na seção anterior.

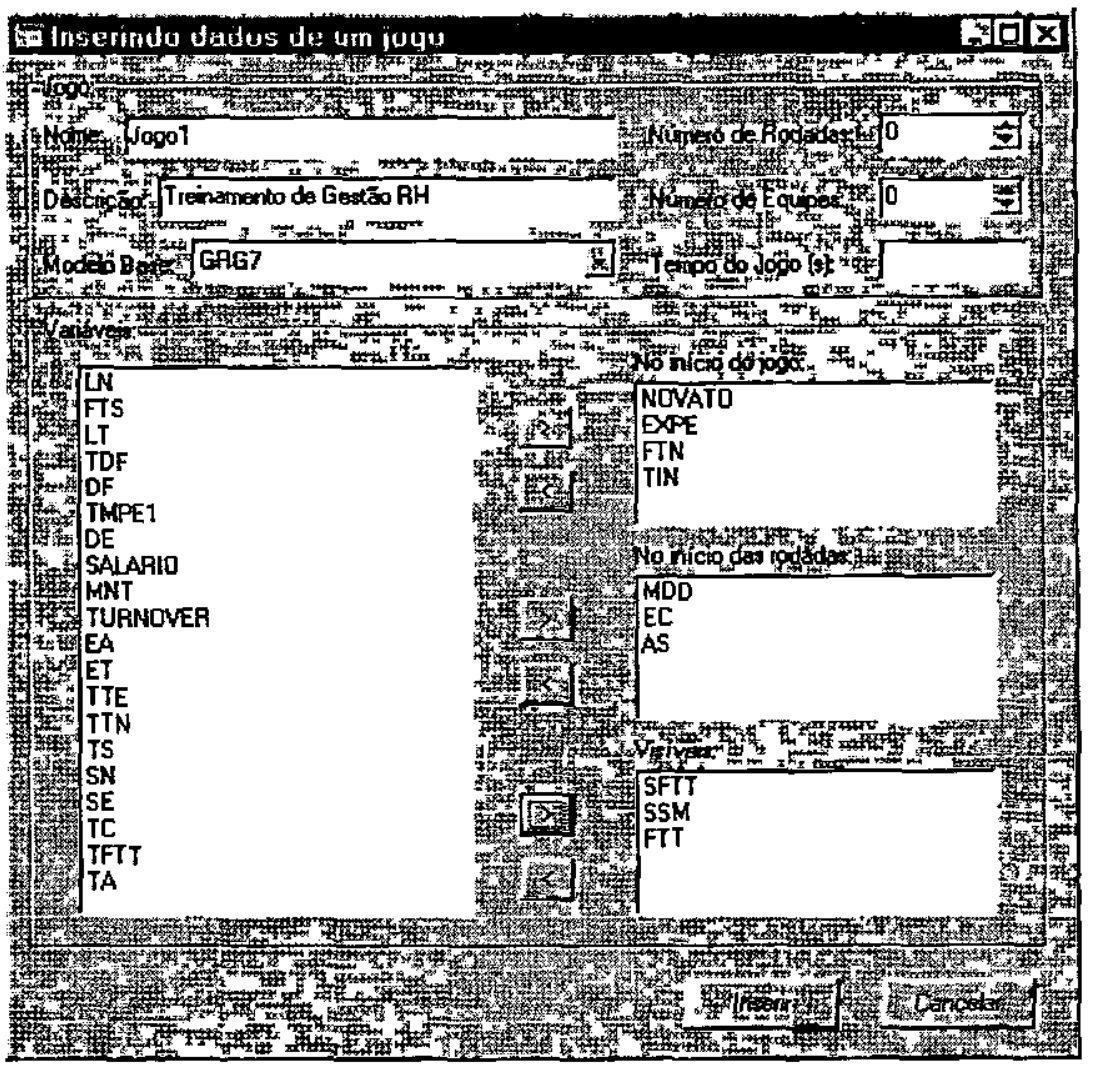

Figura 5.4 - Interface para inclusão de um jogo

Inicialmente, o coordenador deve atribuir um nome e uma breve descrição para o jogo, definir o número de rodadas, o tempo de duração, o número de equipes que irá participar do jogo e o modelo dinâmico em que o jogo será baseado. Ao escolher o modelo, o quadro de variáveis é preenchido com todas as chamadas variáveis (niveis, taxas, constantes e variáveis) que compõem o modelo escolhido. Destas variáveis o coordenador deverá escolher quais serão as variáveis iniciais, alteráveis e visíveis. Conforme é apresentado na Figura 5.4 as variáveis iniciais são: NOVATO (Força de Trabalho - Novato), FTN (Força de Trabalho Necessária), EXPE (Força de Trabalho - Experiente) e TIN (Tempo de Instrutor por Novato); as variáveis alteráveis são: AS (Ajuste Salarial), EC (Espera para Contratação) e MDD (Média Diária de Dedicação); e as variáveis visíveis são: SFTT(Somatório da Força de Trabalho Total), SSM (Somatório do Salário Mensal) e FTT(Força de Trabalho Total).

Quando o jogo já existe e o coordenador deseja alterar algum dado dele, como por exemplo, definir outras variáveis alteráveis ou aumentar o número de rodadas, ele deve escolher a opção Criar elou preparar um jogo. Na próxima interface apresentada o coordenador deve escolher o jogo que deseja alterar da lista de jogos visualizados em uma tabela e escolher a opção Alterar do menu. Esse procedimento é chamado de Preparação de um jogo e utiliza a interface apresentada na Figura 5.5. Finalmente, com um jogo já criado pode-se dar início a sua execução. 


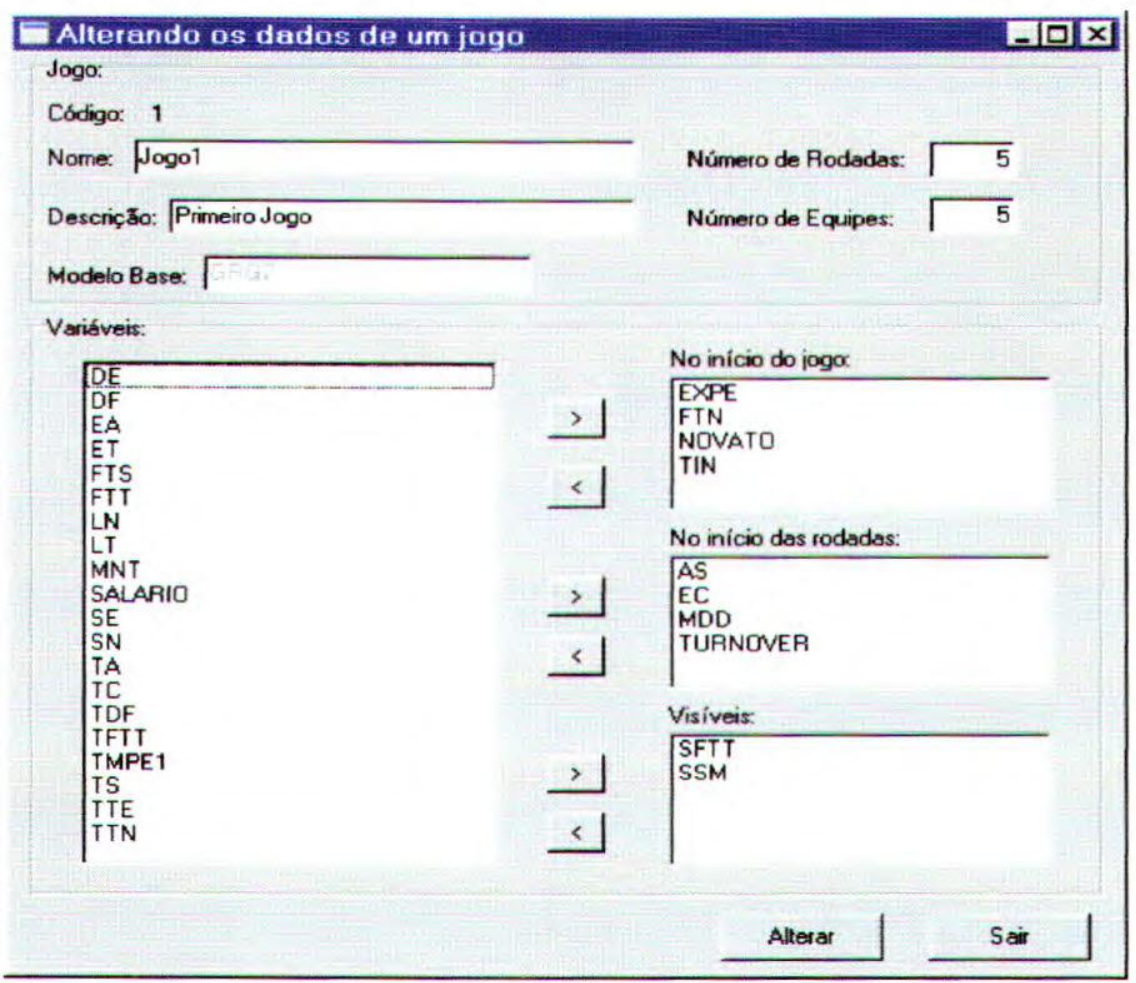

Figura 5.5 - Interface para alteração ou preparação do jogo

\subsubsection{Execução do Jogo}

Para um melhor entendimento, o procedimento de execução do jogo proposto na seção 5.3 foi subdividido em 5 passos que são organizados na Figura 5.6 e descritos logo a seguir.

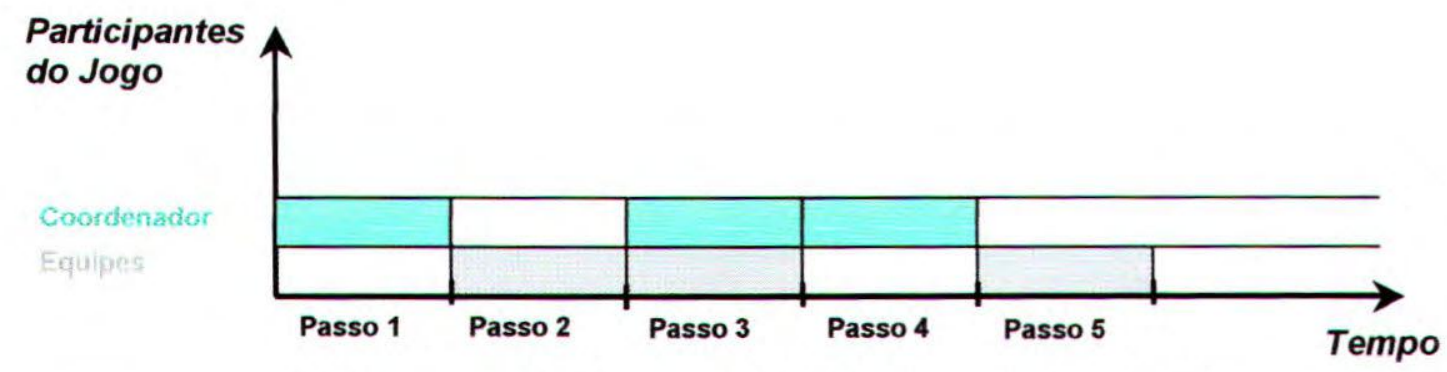

Figura 5.6 - Passos executados em uma partida do jogo

\section{$\underline{1^{\circ} \text { Passo }}$}

O coordenador deve escolher a opção Coordenar um jogo da interface apresentada na Figura 5.2. Logo em seguida será apresentada a interface da Figura 5.7, em que o coordenador deve escolher o jogo que será executado e as variáveis que deseja visualizar de cada equipe. 


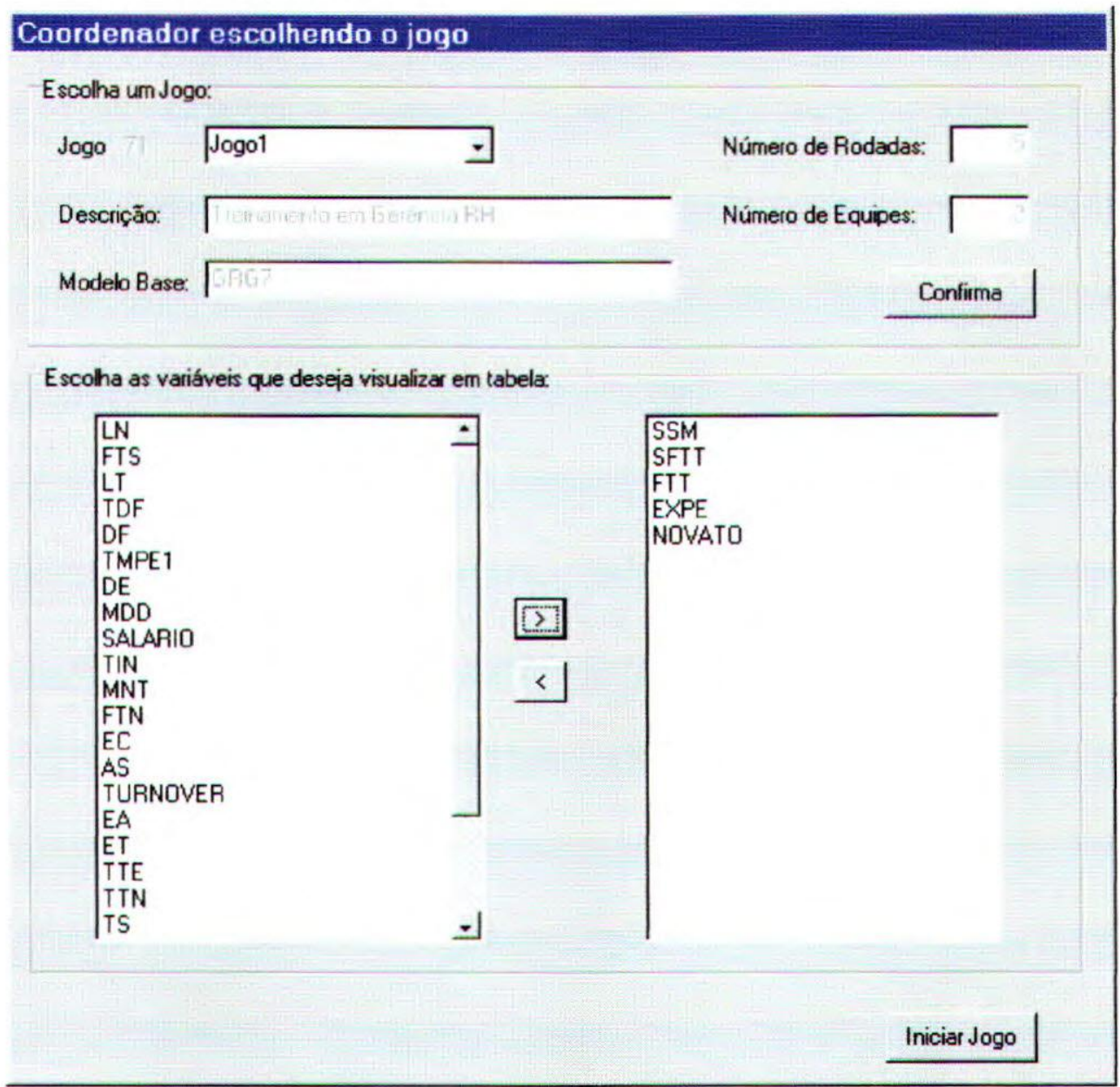

Figura $5 . \overline{7}$ - Interface do coordenador para escolha do jogo

Ao ativar o botão Confirmar, o jogo escolhido pelo coordenador já poderá ser iniciado pelas equipes. Além disso, o coordenador informa e orienta as equipes sobre os objetivos e a dinâmica do jogo.

De acordo com a Figura 5.7 o jogo escolhido pelo coordenador será aplicado a duas equipes em cinco rodadas.

\section{$\underline{2^{\circ} \text { Passo }}$}

Cada equipe se organiza, estuda as informações do material recebido (que é o texto apresentado no Anexo A), e define os valores iniciais das variáveis do jogo para a primeira rodada, que corresponde ao primeiro período ou ciclo (neste caso, um período equivale a um mês). Cada equipe, executando a ferramenta de seu respectivo equipamento computacional, atribui os primeiros valores às variáveis iniciais e alteráveis e visualiza os resultados da primeira rodada do jogo, gerados pelo simulador. A Figura 5.8 apresenta a interface visualizada pela Equipe 2 e os valores definidos por ela ao iniciar o jogo. 


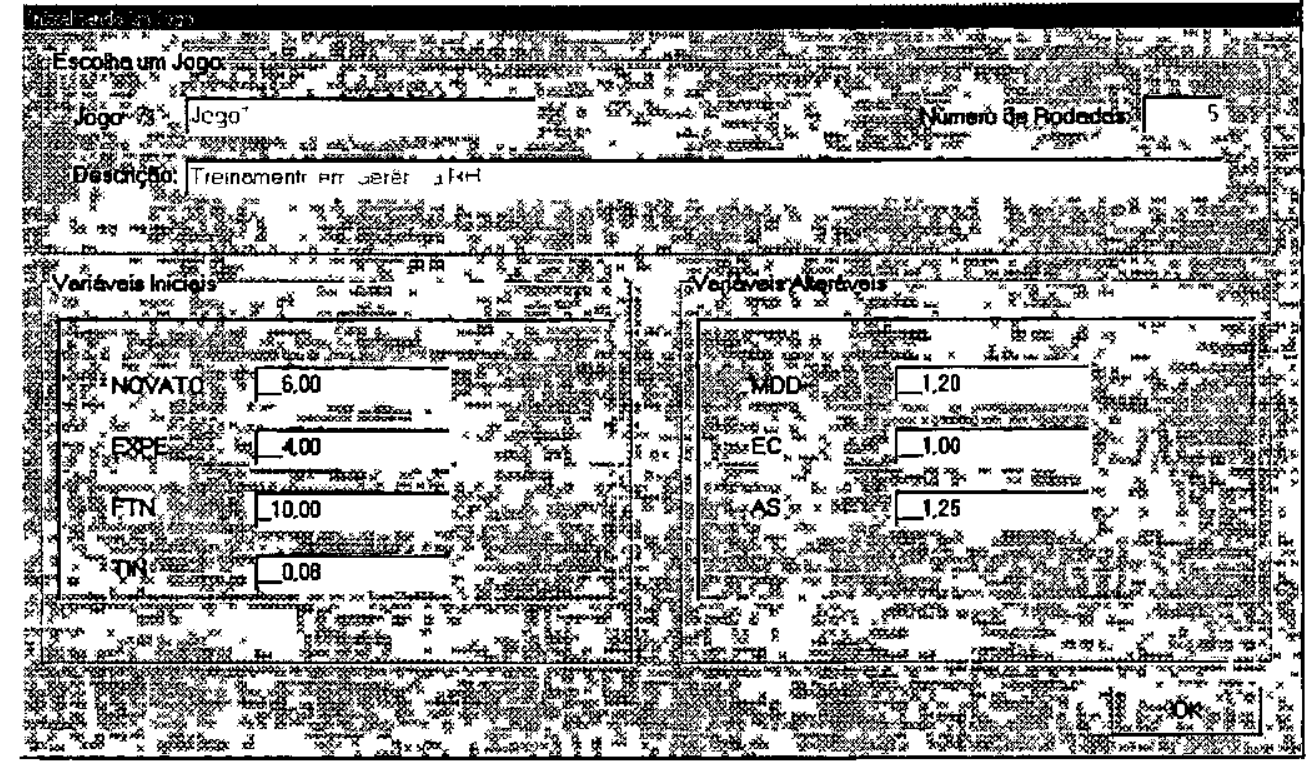

Figura 5.8 - Interface da Equipe 2 no inicio do jogo

Como pode ser observado na Figura 5.8 a Equipe 2 decidiu iniciar o jogo com 6 Experientes e 4 Novatos já que a Força de Trabalho Necessária definida foi 10 pessoas por mês. Neste caso, cada experiente irá permanecer $8 \%(T I N=0,08)$ de suas 9 horas e 30 minutos de dedicação diária ao trabalho $(M D D=1,20)$ treinando um novato. Inicialmente, houve um ajuste salarial de $0,25 \%(A S=1,25)$ e cada contratação de novato levará 1 mês para ser efetivada $(E C=1,00)$, ou seja, verificada a necessidade de contratação de novas pessoas somente após 1 mês (mês gasto no processo de seleção e contratação) estes novatos estarão de fato trabalhando no projeto.

\section{$\underline{3^{0} \text { Passo }}$}

Este passo corresponde ao ciclo repetitivo do jogo em que as equipes jogadoras jogam uma rodada do jogo, analisam os resultados obtidos e tomam novas decisões para a próxima rodada. Esse ciclo permanece se repetindo pelo número de rodadas estabelecidas pelo coordenador. As Figura 5.9a e 5.9b apresentam as interfaces visualizadas pela Equipe 2 e seus respectivos resultados durante a execução do jogo. Nessa interface as equipes também têm a opção de acompanhar suas jogadas por meio de um gráfico.

Conforme pode ser observado na Figura 5.9a a Equipe 2 decidiu aumentar no terceiro mês a média diária de dedicação dos funcionários de $M D D=1,20$ para $M D D=1,30$ já que a

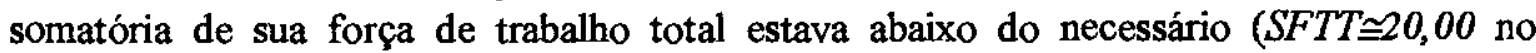
terceiro mês) e poderia causar um atraso na data final do projeto. 


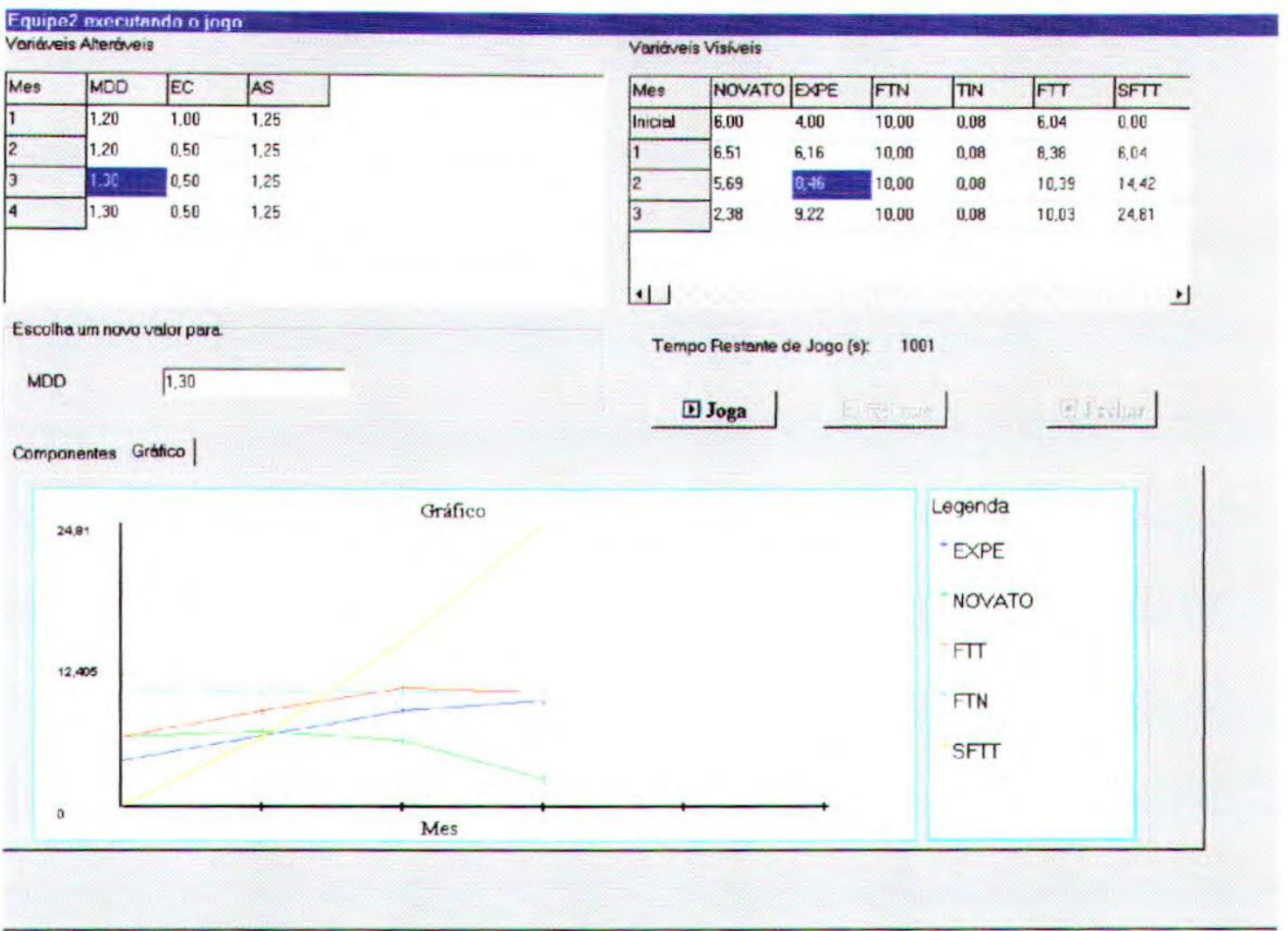

Figura 5.9a - Interface visualizada por uma equipe durante a execução do jogo

A Figura 5.9b apresenta o resultado do jogo obtido pela Equipe 2 após os cinco meses de duração de uma rodada. De acordo com os valores apresentados pela equipes, esta não conseguiu terminar o projeto a tempo pois obteve 45,14 Homens/Mês $(S F T T=45,14)$ quando deveria apresentar um valor mais próximo de 50 Homens/Mês. Desta forma, a equipe necessitaria de mais alguns dias para conseguir terminar o projeto.

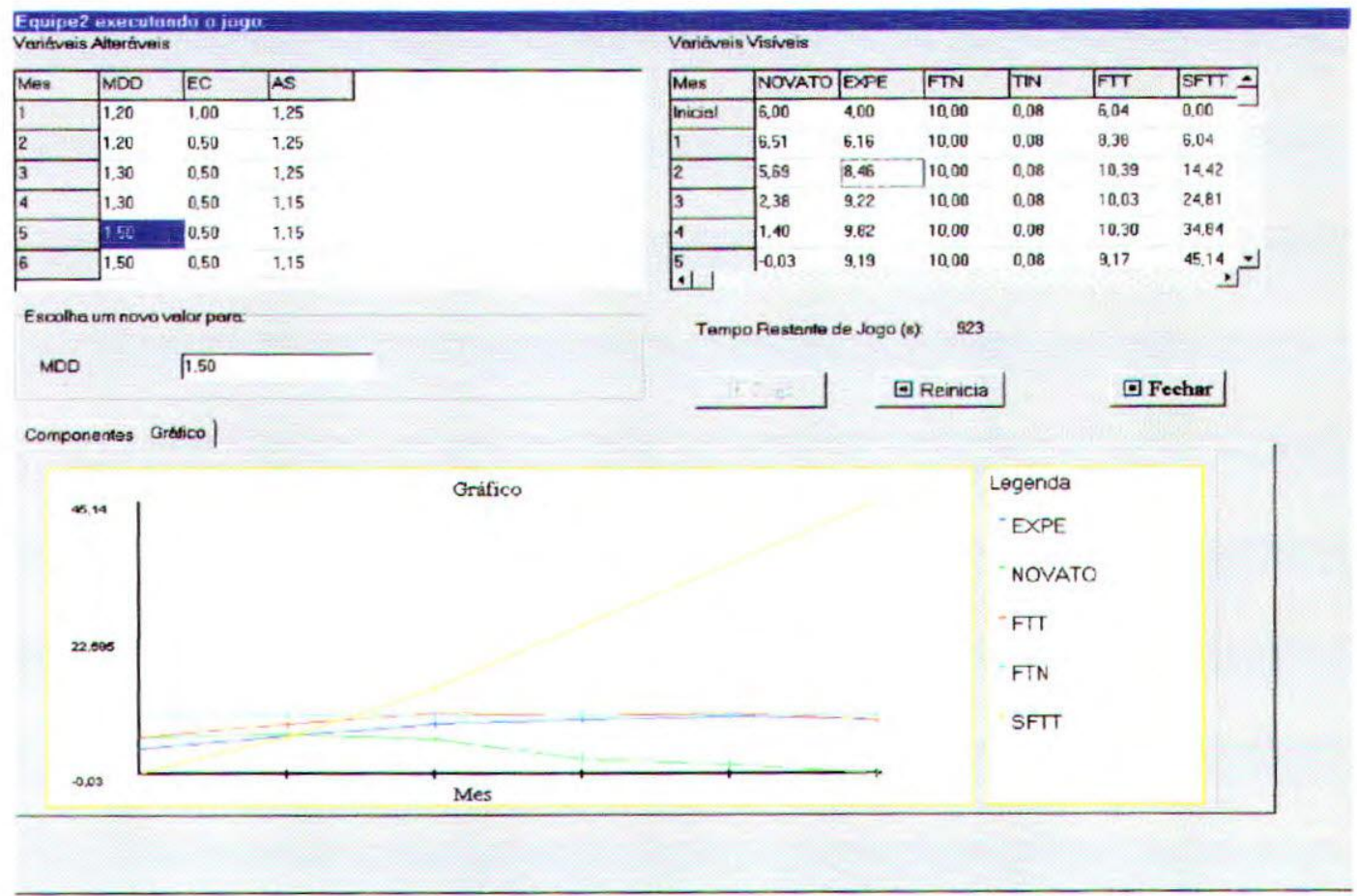

Figura 5.9b - Interface visualizada por uma equipe durante a execução do jogo 
Durante o ciclo repetitivo são apresentados ao coordenador os resultados de cada equipe em uma janela, sendo que cada janela apresenta os resultados de uma equipe organizados em uma tabela. Como pode ser observado na Figura 5.10, as variáveis apresentadas nas tabelas de cada equipe foram aquelas escolhidas anteriormente pelo coordenador na subseção 5.4.1.

Nesta interface o coordenador poderá acompanhar os resultados apresentados pelas equipes e orientá-las em suas novas decisões durante a execução do jogo.

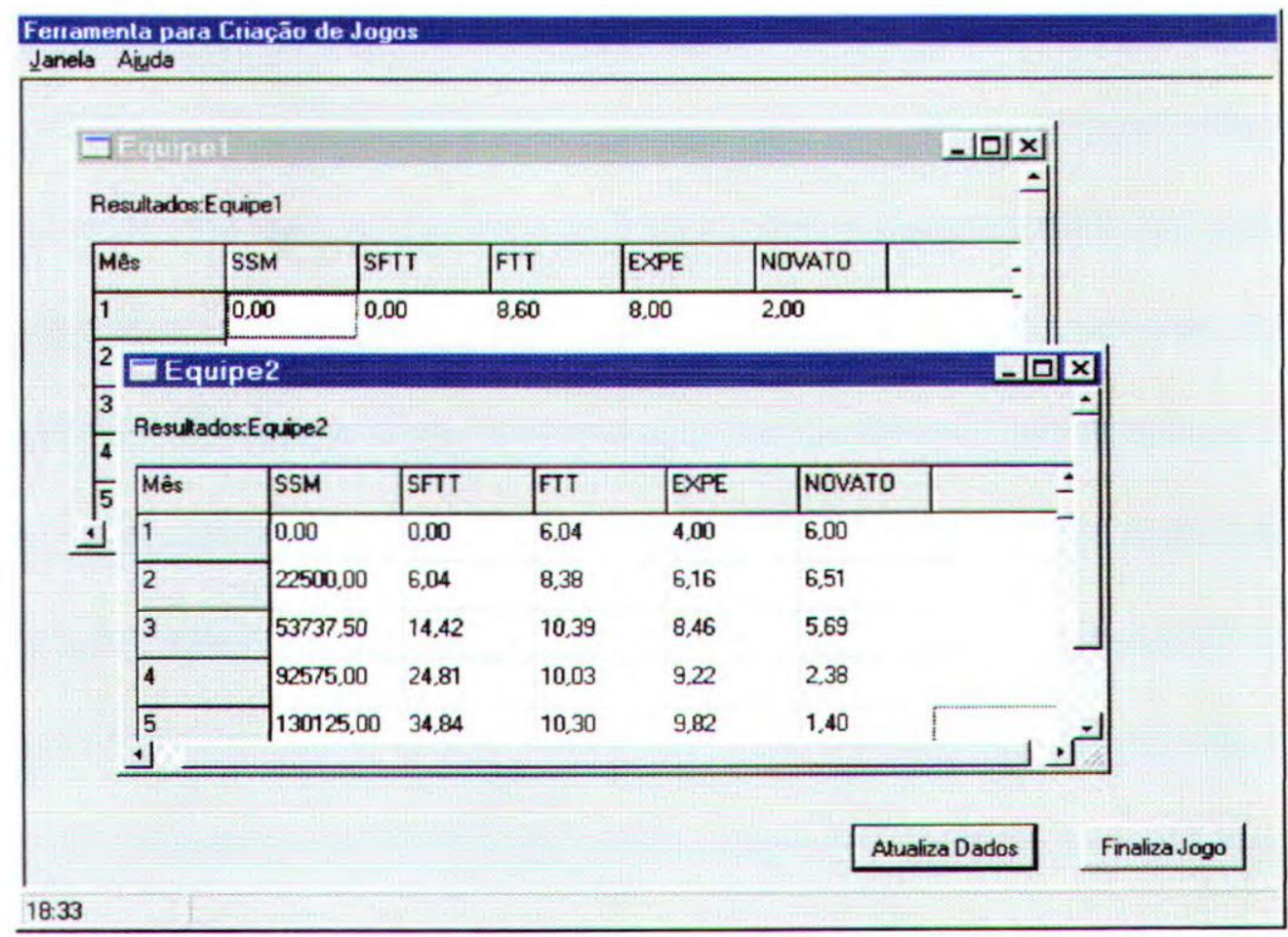

Figura 5.10 - Interface do coordenador durante a execução do jogo

\section{$\underline{4^{\circ} \text { Passo }}$}

Após todas as equipes terminarem a partida do jogo o coordenador poderá, com base nos dados que está visualizando em sua interface, analisar e avaliar o desempenho e as estratégias desenvolvidas por cada uma das equipes e decidir qual é a equipe vencedora desta partida.

Pelos resultados apresentados anteriormente por cada equipe o coordenador pode avaliar e concluir qual foi a equipe vencedora.

\section{$\underline{5^{0} \text { Passo }}$}

As equipes poderão reiniciar o jogo, ou seja, jogar mais uma partida. Entretanto, isto só será possível com a permissão do coordenador. Enquanto o coordenador não finalizar a partida do jogo e iniciar uma outra, as equipes ficarão impossibilitadas de iniciar uma nova partida. 


\subsection{Avaliaçăo da Ferramenta}

A ferramenta foi validada por equipes de alunos do LABES. O jogo desenvolvido neste trabalho e apresentado no Anexo A foi aplicado a duas equipes formadas por um integrante cada uma.

Em termos garais a funcionalidade da ferramenta apresentou bons resultados e eficiência para os objetivos propostos neste trabalho. Entretanto, devido à utilização do banco de dados escolhido - Microsoft Access 97 e ao acesso remoto a este banco, durante a aplicação do jogo os resultados obtidos por cada equipe demoravam a serem apresentados. No entanto, o desempenho pode ser melhorado utilizando um banco de dados mais eficiente.

\subsection{Considerações Finais}

Neste capítulo foram apresentadas as alterações feitas no modelo dinâmico de gerenciamento de recursos humanos de projetos de software proposto por Hamid e Madnick (1991). Esse modelo foi utilizado no desenvolvimento do jogo de empresa apresentado na seção 5.3. Também foram apresentados neste capítulo o processo de criação de um jogo e a dinâmica de sua execução, que envolve o coordenador e as equipes jogadoras.

No próximo capítulo são apresentadas as contribuições e as futuras pesquisas que poderão ser desenvolvidas a partir deste trabalho. 


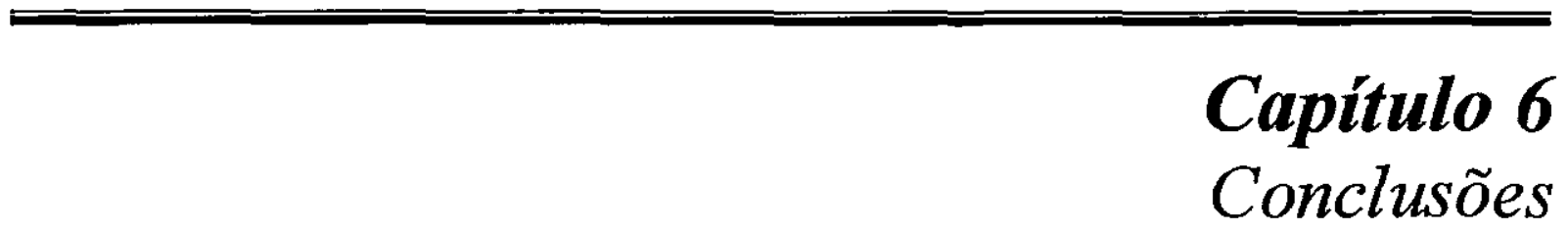




\subsection{Considerações Gerais}

Conforme o estudo realizado nesta dissertação de mestrado os jogos de empresa são usados principalmente como opção de ensino de técnicas de gestão e tomada de decisão em um ambiente laboratorial controlado. Segundo alguns autores, a utilização dos jogos em treinamentos tem vantagens didáticas e pedagógicas muito importantes (Cohen, 1961). No jogo de empresa faz-se um exercício de tomada de decisão com base em um modelo de um cenário empresarial. O resultado da tomada de decisões baseia-se na "execução do modelo", ou seja, sua simulação. Os resultados de treinamentos realizados com essa técnica permitem a assimilação e aplicação de conceitos teóricos e tem-se mostrado bastante eficaz.

Muitas áreas do conhecimento humano têm-se apropriado dessa prática e hoje são bastante comuns os jogos empresariais na área de administração de empresas e na área de engenharia de produção. Segundo Shannon, as simulações nas quais o componente humano e o computador interagem são muitas vezes chamadas de jogos - de empresas, de guerra, etc (Shannon,1975).

Nesse contexto, uma ferramenta genérica para apoiar automaticamente a criação e aplicação de jogos de empresa, além de permitir uma aprendizagem experimental e gerencial do processo gerencial, também permite investigar o desenvolvimento de jogos na área de projetos de software. A ferramenta apresentada neste trabalho satisfaz a esses objetivos.

\subsection{Contribuições}

Este trabalho apresentou duas importantes contribuições para as áreas de Jogos de Empresa e para a área de Gestão de Projetos de Software. A primeira contribuição foi o desenvolvimento de uma ferramenta para a criação de Jogos de Empresa baseados na teoria da Dinâmica de Sistemas. Conforme foi visto no capítulo 3, há várias ferramentas para apoiar a criação e a simulação de modelos na Dinâmica de Sistemas, mas nenhuma delas com as características explícitas necessárias para o apoio de Jogos de Empresa. A ferramenta desenvolvida apresenta essas características.

A Segunda contribuição foi o desenvolvimento de um Jogo de Empresa para a área de Gestão de Projetos de Software, baseado no modelo de Abdel-Hamid e Madnick (1991). Esse jogo serviu para testar a ferramenta, mas mais do que issso, serviu como uma "prova do conceito", isto é, o jogo em si não é propriamente a contribuição, pois pode e deve ser melhorado, ampliado e melhor testado na prática. Mas ele é importante na medida em que, com um caso concreto, torna-se mais fácil a partir de agora desenvolver outros jogos semelhantes e mais aperfeiçoados. 


\subsection{Trabalhos Futuros}

A ferramenta foi desenvolvida para apoiar Jogos de Empresa não interativos em que durante a aplicição de um jogo as decisões de uma equipe não afetam as decisões das demais e cada equipe chega a resultados independentes, que podem ser comparados entre si ou a um padrão. Desta forma, uma importante sugestão para outros trabalhos nessa linha de pesquisa é a elaboração de jogos interativos que, por meio de uma interação mais estimulante e competitiva, podem se tornar mais eficazes ao apoiar o treinamento gerencial.

Outra importante sugestão de melhoria da aplicação da técnica de Jogos de Empresas utilizando a ferramenta é torná-la capaz de gerenciar alterações ou inclusões de novos elementos pelo coordenador no cenário em que o jogo está se desenvolvendo, ao longo jogo. Com isso a aplicação de um jogo se torna mais realista, resultando em um treinamento mais eficiente e dinâmico que representa o que realmente pode acontecer em uma situação real.

Outros trabalhos poderão ainda se dedicar ao estudo de novos modelos que representem outros áreas do processo de desenvolvimento de software. Como por exemplo, os outros subsistemas sugeridos por Abdel-Hamid e Madnick (1991) apresentados no capítulo 2, para as atividades de Produção de Software, Planejamento e Controle. Além disso, outros experimentos poderiam ser realizados para melhor testar o jogo desenvolvido neste trabalho e avaliar a sua eficácia, comparando-o com os resultados produzidos por outras formas de treinamento. 


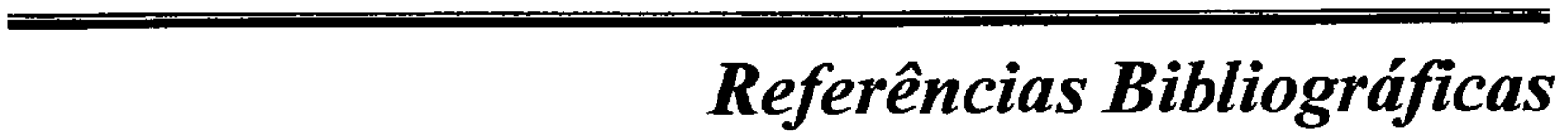


(Abdel-Hamid \& Madnick, 1991)

Abdel-Hamid, Tarek; Madnick, Stuart E. Software Project Dynamics: An Integrated Approach, Pretice-Hall Inc., Englewood Cliffs, New Jersey, 1991.

(Abde!-Hamid, 1989a)

Abdel-Hamid, Tarek Lessons Leamed from Modeling the Dynamics of Software Development. Communications of the ACM, nro 12, vol 32 (1989), 1426-1438.

(Abdel-Hamid, 1989b)

Abdel-Hamid, Tarek The Dynamics of Software Project Staffing: A System Dynamics Based Simulation Approach, IEEE Transactions on Soffware Engineering, nro 2, vol 15 (1989), 109-119.

(Accioly, 1994)

Accioly, Ruy Cordeiro Jogos de Empresas, São Carlos, 1994, 84p. Trabalho de Graduação, Engenharia de Produção, Universidade Federal de São Carlos.

(Beppu, 1984)

Beppu, C.I. Simulaçăo em forma de "Jogo de Empresas", São Paulo, 1984, 198p. Dissertação (Mestrado), Faculdade de Economia e Administração, Universidade de São Paulo.

(Boehm, 1981)

(Cohen \& Rhemman, 1961)

(Collofello et.al., 1996)

Boehm, B. Software Engineering Economics, Prentice-Hall, Englewood Cliffs, New Jersey, 1981.

Cohen, K.; Rhemman, E. The role of management games in education and reserarch management science. The Institute $0^{-}$ Management Science, 7(2), jan 1961, p.131-166.

James S. Collofello; Zhen Yang; Derek Merrill; loana Ru John C. Tvedt Modeling Soffware Testing Processes, $[0$ line], (04/03/1999), Disponivet tha tritemı http://www.eas.asu.edu/ sdm/publications.html

(Forrester, 1961)

Forrester, Jay W. Industrial Dynamics. The M.I.T. Pres Massachusetts, 1961.

(Garcia, 1998)

Garcia, R.E. Uma Ferramenta de Apoio à Dinámica , Sistemas, São Carlos, 1998. Np. Dissertação (Mestrado) Instituto de Ciências Matemáticas e de Computação, Universidade de São Paulo.

(Goelzer, 1972)

Goelzer, L. Simulação de Sistemas - anállse do conceito de simulação, Grupo de Desenvolvimento Científico, IBM, Brasil, 1972.

(Gramigna, 1994)

Gramigna, M.R. M. Jogos de Empresas, Makron Books do Brasil Editora Itd, São Paulo, 1994. 138p.

(Hansen, 1996)

Hansen, Gregory A. Simulation Software Zevelonment Process, IEEE Computer, jan 1996, p. 73-77.

(Houston, 1996)

Houston, D. System Dynamics Modeling and Simulation of Software Development: A Tutorial, [On-line], (04/03/1999), Disponivel na Intemet: http://wnw.eas.asu.edu/ sdm/publications.html

(Jones, 1991)

Jones, C. Applied Soffware Measurement: Assuring Productivity and Quality, McGraw-Hill, New York, 1991 
(Keys \& Wolfe, 1990)

(Law \& David, 1991)

(Mackulak, 199i)

(Martinelli, 1988)

(Memill \& Collofello, 1997)

(Naylor et.al., 1971)

(Pressman, 1995)

(Pritsker, 1986)

(Rocha, 1997)

(Sauaia, 1989)

(Senge, 1990)

(Shubik et.al., 1971)

(Statz, 1994)

(Strack, 1984)

(Sycamore, 1996)

(Tanabe, 1977)

(Wells, 1990)
Keys, J. B; Wolfe, Joseph The role of management games and simulations for education and research Joumal of Management, n. 2,vol.16, 1990, p.307-336.

Law, Averill M.; Kelton, W. David Simulation Modeling and Analysis, $2^{\text {nd }}$ ed., McGraw-Hill, New York, 1991.

Mackulak, Gerald T. Lectures in IEE 545, Introduction to Simulation (Spring), Arizona State University, 1991.

Martinelli, D. P. A utilização dos jogos de empresas no ensino de administração, 23 (3), julho/setembro 1988, p.24-37.

Improving Software Project Management Skills Using a Software Project Simulator, [On-line], (04/03/1999), Disponivel na Intemet: http://uww.eas.asu.edu/ sdm/publications.html

Naylor, T. H., et. al. Técnicas de simulaçáo em computadores. Editora Vozes, São Paulo, 1971. 400p.

Pressman, Roger S. Engenharia de Software. Editora Makron Books, São Paulo, 1995. 1056p.

Pritsker, A. Alan B. Introduction to simulation and SLAM II, New York John Wiley \& Sons, 1986.

Rocha, L. A. Giordano Jogos de Empresa: Desenvolvimento de um Modelo para Aplicaçåo no Ensino de Custos Industriais, Florianópolis, 1997, Dissertação (Mestrado), Departamento de Engenharia de Produção e Sistemas, Universidade Federal de Santa Catarina.

Sauaia, C. Jogos de Empresas: tecnologia e aplicaçăo, São Paulo, 1989. 215p. Dissertação (Mestrado), Faculdade de Economia e Administração, Universidade de São Paulo.

Senge, Peter M. A Quinta Disciplina: Arte, Teoria e Prática da Organização de Aprendizagem, Editora Best Seller, São Paulo, 1990.

Shubik, M.; Kerstenetzky, I.; Naylor, T. H. Modelos, simulações e jogos, Revista Brasileira de Economia, 25 (1) jan/mar 1971, p.9-37.

Statz, J. Training Effective Project Managers, American Programmer, 1994. p.43-48.

Strack, J. GPSS: modelagem e simulaçăo de sistemas. LTC Editora, Rio de Janeiro,.1984. 51p.

Sycamore, D.M. Improving Software Project Management Through System Dynamics Modeling, [On-line], (04/03/1999), Disponivel na Intemet: http://unw.eas.asu. edu/ sdm/publications.html

Tanabe, M. Jogos de Empresas, São Paulo, 1977, 117p., Dissertação (Mestrado), Faculdade de Economia e Administração, Universidade de São Paulo.

Well, Robert Management games and simulations in management development: na introduction. The Jounal of 
Management Development, England, МСВ University Press, n.2, vol.9, 1990, p.4-5.

(Wilhelm, 1997)

Wilhelm, Pedro Paulo Hugo Uma Nova perspectiva e uso dos Jogos de Empresa, Florianópolis, 1997, Tese (Doutorado), Departamento de Engenharia de Produção e Sistemas, Universidade Federal de Santa Catarina.

(Wirth, 1976)

Wirth Niklaus, Algorithms + data structures = programs Englewood Cliffs: Prentice-Hall, 1976.

(Yourdon, 1996)

Yourdon, E. Rise \& Resurrection of the American Programmer. Yourdon Press, cap. 4, 1996. 


\section{Anexo A}

\section{O Jogo}

\section{Introdução}

O jogo simula o aspecto gerencial do desenvolvimento de software. Cada equipe que participa do jogo representa o papel do gerente de projeto.

O gerente do projeto deve tomar decisões sobre a contratacaa de novas pessoas, conforme a necessidade do projeto; a transformacaão de pessoas recém-contratadas no projeto em profissionais à medida que vão adquirindo experiência; e a eventual saida de profissionais que pedem demissão ou se aposentam.

Do ponto de vista do gerente do projeto, os membros da equipe de desenvolvimento podem ser classificados em novatos ou experientes. Essa classificação é necessária para caracterizar a diferença de produtividade existente entre um novato e um experiente. A produtividade de um novato é, em média, $50 \%$ menor que a produtividade de um experiente. Todas as pessoas que começam a trabalhar em um projeto são consideradas novatas, pois requerem um treinamento para se familiarizar com a organizacaão e detalhes desse projeto. Esse treinamento é oferecido pelos próprios membros experientes da equipe que acabam tendo seu tempo de produção diminuido.

Os membros da equipe poderão deixar de trabalhar no projeto por três razões: transferência, aposentadoria ou demissão. Quando há a necessidade de transferir membros da equipe, os primeiros a serem transferidos são os novatos, aqueles que ainda estão sendo treinados. Se ainda assim houver a necessidade de transferir mais pessoas, os próximos a serem transferidos são os experientes. Aqueles que estão deixando o projeto precisam de um tempo de trabalho enquanto se processa a transferência.

\subsection{Objetivo}

O objetivo do jogo é obter o melhor desempenho no gerenciamento dos recursos humanos do projeto. Esse desempenho será avaliado pelas estratégias utilizadas pelas equipes para atender às metas do projeto. A principal meta é atingir um determinado nível de esforço aplicado ao projeto usando a medida homens/mês dentro de um determinado tempo máximo, em meses. Para o projeto atual estima-se que para seu desenvolvimento são necessários homens/mês em um tempo máximo de meses.

\subsection{Como funciona o jogo}

\section{Equipe}

Primeiramente, a equipe precisa se organizar e elaborar uma estratégia para atingir as metas do projeto. Para isso, é necessário analisar os dados iniciais apresentados pelo coordenador e definir os valores das variáveis iniciais do jogo, descritas em detalhes na próxima seção.

\section{Coordenador}

O Coordenador tem a função de conduzir o jogo, definindo algumas variáveis e alterando outras conforme as decisões tomadas pela equipe.

\section{Software Simulador}

O software simulador tem a função de processar as decisões tomadas pela equipe. Com essas informações é realizada a simulação da dinâmica existente no gerenciamento dos recursos humanos 
de um projeto e relatórios são emitidos em forma de tabelas e gráficos para auxiliar a equipe em suas tomadas de decisões.

\section{Fontes de Informação}

As fontes de informação necessárias para a equipe tornar suas decisões serão apresentadas em forma de gráficos e tabelas mensais. Esses resultados apresentam como está o desempenho da equipe por mieio de variáveis, algumas delas alteráveis durante o jogo, e outras que servirão de base para o próximo ciclo de tomada de decisão, tais como: número total de novatos, número total de experientes e força de trabalho total.

\subsection{Dinámica do jogo}

1. Inicialmente 0 coordenador do jogo informa às equipes os objetivos $\theta$ os dados necessários para a equipe tomar suas primeiras decisões quanto às variáveis iniciais.

2. A equipe se organiza, estuda os dados e o material recebidos, e define os valores iniciais das variáveis do jogo para o próximo ciclo(período), que corresponde a 1 mês. As decisões tomadas pela equipe são entregues ao administrador que irá alimentar o software simulador.

3. O software simulador realiza a simulação dos novos dados, processa as informações e apresenta os resultados à equipe.

4. Após cada ciclo, a equipe analisa seu desempenho e toma novas decisões.

5. No fim do jogo o coordenador avalia o desempenho e as estratégias da equipe .

\section{O que está em Jogo na Empresa}

Neste momento em que já são conhecidos o objetivo e a dinâmica do jogo, você irá saber o que realmente esta em jogo na empresa. Serão apresentadas as variáveis que o gerente deverá considerar nas suas tomadas de decisão. Algumas destas variáveis são definidas antes do início do jogo e não poderão mais ser alteradas. Outras variáveis poderão ser alteradas durante 0 jogo, ou seja, a cada ciclo (rodada).

\subsection{Variáveis Definidas no Início do Jogo}

\section{Força de Trabalho dos Novatos (Novato)}

A Força de Trabalho de Novatos representa o número de pessoas recém-contratadas ou recém-transferidas de outros projetos intemos da empresa para o desenvolvimento do projeto. 0 gerente deve garantir a estas novas pessoas um treinamento adequado até toma-las membros experientes da equipe de produção. Para definir a Força de Trabalho de Novatos é necessário considerar o tempo em que as pessoas estarão em treinamento e a produtividade de um novato, que é $50 \%$ menor que a produtividade de um experiente.

\section{Força de Trabalho dos Experientes(Expe)}

A Força de Trabalho dos Experientes representa o número de pessoas experientes que estão trabalhando no projeto. Os experientes são os engenheiros de software experientes que começaram a trabalhar no projeto desde o inicio ou como novatos que foram treinados durante algum tempo até se tornarem completamente integrados ao projeto. Faz parte do trabalho do experiente treinar os novatos do projeto. Apesar do experiente ser mais produtivo que um novato, sua produtividade diminui conforme aumenta o tempo dedicado ao treinamento de novatos.

\section{Força de Trabalho Necessária (FTN)}

A Força de Trabalho Necessária representa o número de pessoas requeridas a cada mês para o desenvolvimento do projeto. Para decidir o valor desta variável o gerente deve considerar vários 
fatores. Um fator importante é o tempo de duração do projeto. Como parte da função de planejamento o gerente determina o número de pessoas que acredita ser necessário, a cada mês, para concluir o projeto dentro do prazo. Outro fator importante é o esforço total necessário para o desenvolvimento do projeto.

\section{Tempo de Instrutor por Novato (TIN)}

O Tempo de Instrutor por Novato é um percentual médio que um experiente (instrutor) gasta de seu tempo de trabalho para treinar um novato. Supondo como exemplo que essa variável, Tempo de Instrutor por Novato, receba o valor 0.10 . Isto significa que a média que cada novo empregado consome em treinamento é equivalente a $10 \%$ do tempo de trabalho de um experiente.

\subsection{Variáveis Alteráveis Durante o Jogo}

\section{Média de Dedicação Diária (MDD)}

Nesta empresa, enquanto os novatos trabalham o tempo todo somente em um projeto, os experientes podem trabalhar em mais de um projeto ao mesmo tempo. Assim, a Média de Dedicação Diária representa a média de dedicação diária de um experiente em um projeto. Quando essa média está entre os valores 0.5 e 1 , ou seja $0.5<\mathrm{MDD}<1$, significa que o experiente trabalha MDD de seu tempo ( 8 horas diárias) no projeto e o resto de seu tempo em outros projetos; MDD = 1 , significa que o experiente dedica todo seu tempo ao projeto; $1<\mathrm{MDD}<1,5$, significa que o experiente trabalha horas extras no projeto. $\mathrm{O}$ valor de MDD deve pertencer ao intervalo dentre $0 \mathrm{e}$ 1,5 que corresponde de 1 a 4 horas extras diárias.

\section{Espera para Contratação (EC)}

A Espera para Contratação representa um atraso de tempo. 0 que ocorre na maioria das empresas quando um gerente de recursos humanos precisa contratar novas pessoas para um projeto é uma certa demora para que o Departamento de Recursos Humanos consiga recrutar e selecionar novos engenheiros de software, que sempre entrarão no projeto como novatos. Enquanto isso o projeto tem que continuar convivendo com a falta de pessoal e o gerente deve continuar se preocupando com o prazo final do projeto. Assim, a Espera para Contratação representa o atraso de tempo, em meses, a cada rodada do jogo. Quanto menor for esse valor mais rápido as pessoas serão contratadas e, consequentemente, estarão disponiveis mais cedo.

\section{Ajuste Salarial (AS)}

O Ajuste Salarial representa o aumento dado aos salários dos membros do projeto. Quando o valor desta variável é 1 significa que nenhum ajuste esta sendo aplicado ao salário. Se esse valor for alterado para 1,20 por exemplo, significa que um ajuste de $20 \%$ esta sendo aplicado ao salário dos membros do projeto.

\subsection{Variáveis Visíveis do Jogo}

\section{Somátoria da Força de Trabalho Total (SFTT)}

A Somatória da Força de Trabalho Total representa o total de força de trabalho alocada desde o início do jogo para o desenvolvimento do jogo. Essa variável é analisada pelas equipes que tentarão atingir a meta do projeto, que é o nivel máximo de esforço, proposto pelo coordenador, aplicado ao projeto. A fórmula para cálculo desta somatória é:

$$
S F T T=E X P E+N O V A T O / 2-2\left(N O V A T O O^{\star} T I N\right)
$$

Nesta fórmula é realizada uma soma da força de trabalho de Experientes com metade da força de trabalho de Novatos, já que estes por serem novatos possuem uma produção correspondente a 
metade da produção dos Experientes. Dessa soma é subtraida a porcentagem da força do trabalho (Novatos e Experientes) que permanece em treinamento.

\section{Somatória do Salário Mensal (SSM)}

A Somatória do Salário Mensal é uma variável cumulativa que representa o valor total gasto com o pagamento da força de trabalho desde o início do projeto. A fórmula para cálculo desta somatória é:

$S S M=S N+S E$ em que:

$S N=(N O V A T O * U M O N E T A R L A) *(1+A S)$

$S E=\left(E^{*} 3 * U M O N E T A R I A\right) *(1+A S)$

Essa variável representa uma somatória mensal cumulativa do salário pago aos novatos $(S N)$ com o salário pago aos experientes $(S E)$. O salário dos novatos é expresso pelo produto do número de força de trabalho de novatos por uma certa unidade monetária e pelo ajuste salarial correspondente ao mês corrente. O salário dos experientes segue o mesmo raciocínio com a diferente de que um experiente ganha três vezes mais que um novato.

Força de Trabalho Total (FTT)

A Força de Trabalho Total representa o número de total de força de trabalho que é realmente produtiva a cada mês no desenvolvimento do projeto. Assim, as horas dedicadas a treinamento não estão inclusas nesta variável. 